S T A T E OF I L L I N O I S

William G. Stratton, Gozernor

DEPARTMENT OF REGISTRATION AND EDUCATION

VERA M. BINks, Director

NATURAL H ISTORY SURVEY DIVISION

Harlow B. Mills, Chief

Volume 26

B U L L E T I N

Article 2

Largemouth Bass in Ridge Lake,

Coles County, Illinois

GEORGE W. BENNETT

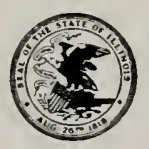

Printed by Authority of the State of Illinois

URBA NA, I L L I N O IS

Norember $195+$ 
S T A T E OF I L L I NOIS

Willia.s G. Stration, Governor

DEPARTIENT OF REGISTRATION AND EDUCATION

VEERA M. BINKS, Director

BOARD OF NATURAL RESOURCES AND CONSERVATION

IERA MI. BINKS, Chairman

A. E. EMEksox, Ph.D., Biology

i. H. TIFra.ry, Ph.D., Forestry

ROBERT H. A.NDERSON, B.S.C.E., Engineering

Whater H. Newilouse, Ph.D., Geology RoGer ADAMS, Ph.D., D.Sc., Chemisiry Lloyd MOREY, B.A., B.Mus., C.P.A., LL.D., President of the University of Illinois

DELYTE VI. Morris, Ph.D., President of Southern Illinois Universily

\section{NATURAL HISTORY SURVEY DIVISION Urbana, Illinois \\ SCIENTIFIC AND TECHNICAL STAFF \\ HARLOW B. MILLS, Ph.D., Chief \\ Bessie B. EAST, M.S., Assistant to the Chief}

Section of Economic Entomology

George C. Decker, Ph.D., Entomologist and Head

J. H. Bigger, M.S., Enlomologist

L. L. ExGlisil, Ph.D., Entomologis

S. C. ChANDLER, B.S., A ssociale Entomologist

Willis N. Bruce, Ph.D., A ssociale Entomologist

NorMas C. GAs:ox, Ph.D., Associate Entomologist

JoH, M. Wright, Ph.D., Associate Entomologist

Pall Surany, Ph.D., Assistant Entomologist

IV. H. LickMANN, MI.S., A ssistant Entomologist

Rovald H. MEver, B.S., A ssistant Entcmologist

Join W. Mattesox, B.A., Field A ssistant

ROBERT S.NeTsiNGer. M.S., Field Assistant

SUE E. WATKINS, Technical Assistant

H. B. PETtY, MI.A., Extension Specialist in Enlomology

StEVr.son MoORE, III, Ph.D., Exlension Specialist in Entomology*

Moliax Rao, MI.S.. Research Assistant*

ClareNce E. White, B.S., Research Assislant*

Louise ZiNGroNe, B.S., Research Assistant*

\section{Section of Faunistic Surveys and Insect} Identification

H. H. Ross, Ph.D., Systematic Entomologist and Head

Miltox W. SANDERsox, Ph.D., Associale Taxonomist

Lewis J. Staxvard, JR., Ph.D., Assistant Taxonomist

Philip II. SMrti, Ph.D., Assistant Taxonomist

LEONORA K. GLoYd, M.S., Laboratory Assistant

Virginia A. Whipple, Technical Assistant

\section{Sectlon of Aquatic Blology}

George $W$. Bexsett, Ph.D., Aqualic Biologist and Head

Wrlliam C. Starkett, Ph.D., Associale Aqualic Biologist

R. W. LARInore, Ph.D., Associale Aquatic Biologist

Donald F. Hansen, Ph.D., Assistant Aquatic Biologist

ROBERT D. CROMPTON, Field Assistant

LEONard DURHaM, M.S., Research Assistant*

P. L. MC. NEIL, B.S., Research A ssistant*

Wili.ias F. Childers, B.S., Technical A sistant*

\section{Section of Applled Botany and Plant} Pathology

J. Cepric Carter, Ph.D., Plant Pathologist and Acling Head

J. L. Forsberg, Ph.D., Associale Plant Pathologist

G. H. Boewe, M.S., Assistant Plant Pathologist

R. J. Campana, Ph.D., Assistant Plant Pathologist

I. R. Schneider, Ph.D., Assistant Plant Pathologist

E. B. Himelick, M.S., A ssistant Plant Pathologist RoBert A. Evers, Ph.D., Assislant Bolanist

RoveniA F. Fitz-GERALD, B.A., Technical RoveniA $\mathrm{F}$.

Assistant
HARRY J. KRUEGER, B.S., Special Research Assistant*

\section{Section of Game Research and Management}

T. G. Scotr, Ph.D., Game Specialist and Head

RALPH E. YEATTER, Ph.D. Game Specialist

F. C. Bellrose, B.S., Associale Game Specialist H. C. Hanson, M.S., Assistant Game Specialist J. S. Jordax, Ph.D." Assistant Game Technician Ross J. Miller, M.S., Field Ecologist

Frances D. RobBins, B.A., Technical Assistant William Nuess, Field Assistant

Lysle R. PIETSCH, M.F., Project Leader*

William B. Robertson, JR., M.S., Research Assistant*

JAMES OPSAHL, M.S., Field Assistant*

Robert H. Brough, Field Assistanl*

\section{Section of Publications and Public Relations}

JAMES S. AYARS, B.S., Technical Editor and Head Blanche P. Young, B.A., Assistant Technical Editor

William E. Clark, Assistant Technical Photographer

ROBERT E. TEEGARDIN, Technical Assislant

\section{Technical Library}

RUTH R. WARRICK, B.S., B.S.L.S., Technical Librarian

OlgA E. Grimisger, B.A., Assistant Technical Librarian

Conslltants: Herpetology, Hobart M. Smith, Ph. D., Associale Professcr of Zoology, Unizersity of Illinois; Paracitolog:, NorMa.: D. LEvise, Ph.D., Professor of Veterinary Parasitology and of l'eterinary Research, Unirersily of Illinois.

Employed on co-operative projects with one of several agencies: Illinois Agricultural Extension Service, Illinois Department of Conservation, United States Army Surgeon General's Office, United States Department of Agriculture, United States Fish and Wildlife Service, United States Public Health Service, and others.

This paper is a contribution from the Section of Aquatic Biology.

$(1650-4,500-8-5.4)$

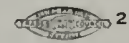



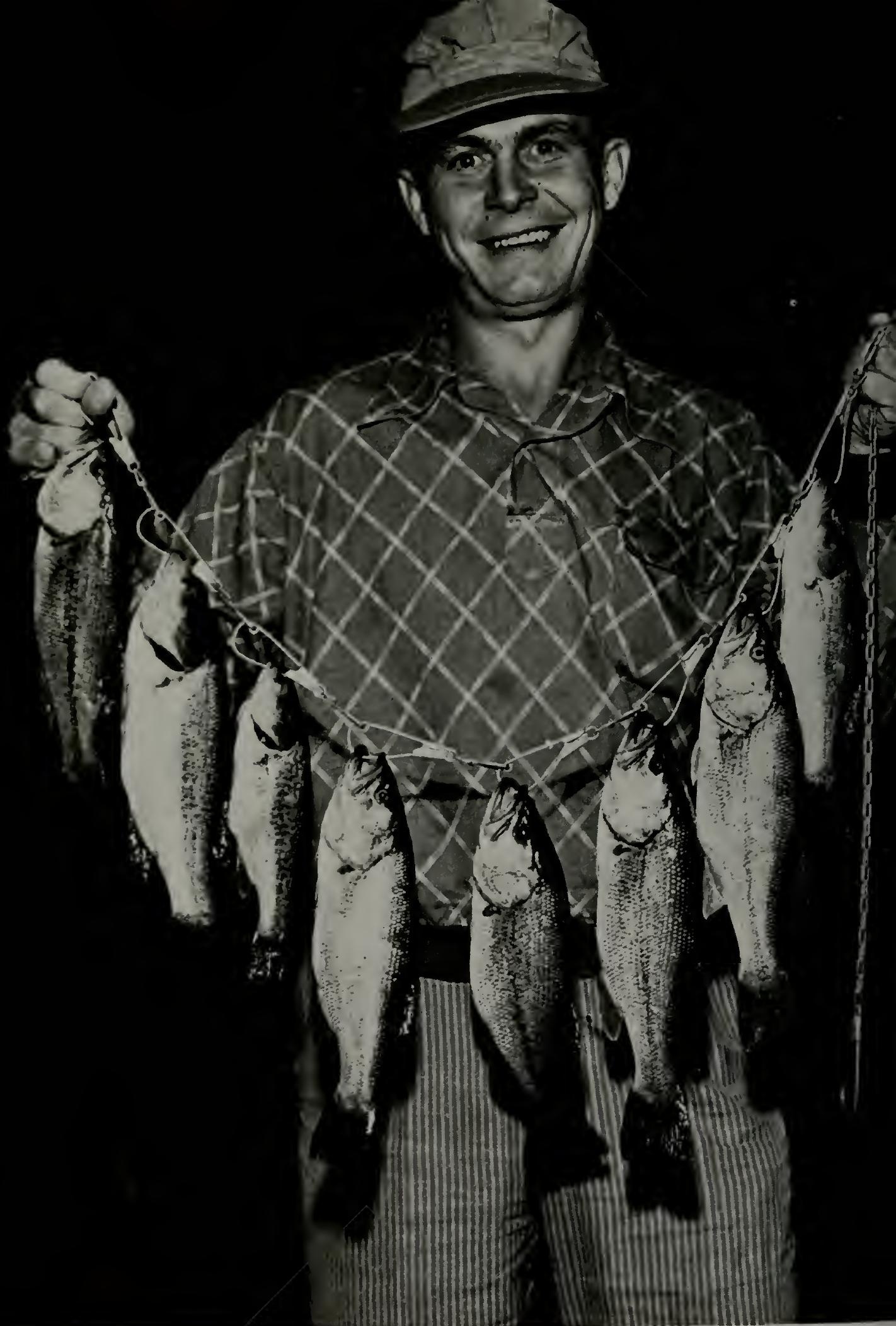

Illinois angler with catch of largemouth bass from Ridge Lake. 


\title{
Largemouth Bass in Ridge Lake, Coles County, Illinois
}

\author{
GEORGE W. B ENNETT
}

I N 1941, when Ridge Lake, in Fox Ridge State Park, Coles County, Illinois, was completed, it was set aside as a study area for the largemouth bass, Micropterus salmoides (Lacépède). Initially, the largemouth was the only species of fish involved in the study. Later, in 1944, the bluegill, Lepomis macrochirus Rafinesque, was added as a companion species for the largemouth, and in 1949 the warmouth, Chaenobryttus coronarius (Bartram), was introduced.

At the time the study was begun, little was known of the factors that control the numerical size of populations of the largemouth, or the maximum total poundage of this species that a lake or pond could support. Extensive censusing of pond fish populations was in progress in various parts of the United States, and some fisheries investigators (Meehean 1942:193; Swingle \& Smith 1941:274; Swingle $1950: 14$ ) assumed that, because in many ponds the total weight of largemouth bass exhibited relationships to the total weight of prey fish present of, say, 1 to 3 or 1 to 4 , such relationships represented the "normal" or optimum ratios. These investigators further assumed that such ratios should be duplicated as nearly as possible in stocking new ponds.

The hypothesis of "normal" ratios between the weight of largemouth bass populations and the weight of populations of prey fish coexisting with the bass was based partially on the assumption of a direct predator-prey relationship between the two groups of fishes. Seemingly logical at the time was the further assumption that growth in a population of largemouths cannot remain "normal" if the population of prey fish drops below a certain predator-prey ratio. Both of these assumptions had to be discarded when research demonstrated that largemouths, once defined as piscivorous, are in fact relatively omnivorous and are able to maintain populations at high numerical and poundage levels when species of fish believed to furnish their principal sources of food are not present. In several artificial ponds in Illinois, largemouth bass populations isolated from other fishes maintained high numerical and poundage levels (Bennett 1951:235, 239 and unpublished records). Conversely, in some Illinois ponds in which largemouth bass were coinhabitants with other species of fish, the bass populations divindled in both numbers and poundages.

In early decades of the present century, the phenomenon of declining populations of largemouth bass, a phenomenon early appreciated by fisheries personnel of the period, was largely responsible for the extensive development of hatchery propa. gation of these bass and for the imposition of certain fishing restrictions, including a closed season, a 10 -inch minimum length limit, and a creel limit of 10 fish, first put in force in Illinois on July 1 , 1923.

Fisheries workers in Illinois have observed often the ability of largemouth bass to expand their populations suddenly to take advantage of new territory. $\dot{A}$ new impoundment is particularly favorable to the successful reproduction of largemouths (Bennett 1946:9). When, for example, a new reservoir is stocked with equal numbers of adult largemouths, white crappies or black crappies, bluegills, and black bullheads, usually the largemouths, during the first spawning season, populate the shore shallows with tremendous numbers of young. Throughout this first season, the young of the other species of fish included with the bass may be so few in number that none can be collected. Probably few workers who have observed this sudden population expansion of hass have recognized its true signifi- 
eance in the production of superior fishing for largemouths, or how to make use of it in monaging the species.

"lhere is little reason to doubt that the "bonanzas" of largemouth fishing that are experienced occasionally by certain anglers in certain locitions in certain years have stemmed from the development of superior populations of largemoutls. 'These populations appear usually as a result of a relatively high survival of bass spawn during a season 2 to + years prior to the "bonanza" year. Such spawning success may be brought about by stocking a new reservoir with a few spawners.

Under natural conditions, any catastrophe which severely decimates a fish population that includes largemouth bass, but which allows the survival of a few bass spawners along with small numbers of adults of other species, will almost always be followed by an unusually large production of young bass. Such a phenomenon as a severe drought or drawdown, winterkill, abnormal predation, disease, or a combination of these might severely reduce a mixed population of fishes and set the stage for the production of a dominant bass brood.

Ridge Lake was stocked with 100 adult largemouth bass on April 30 and May 1, 19+1. A few weeks later, a very large brood of young was produced. When the numerical size of this brood was estimated,

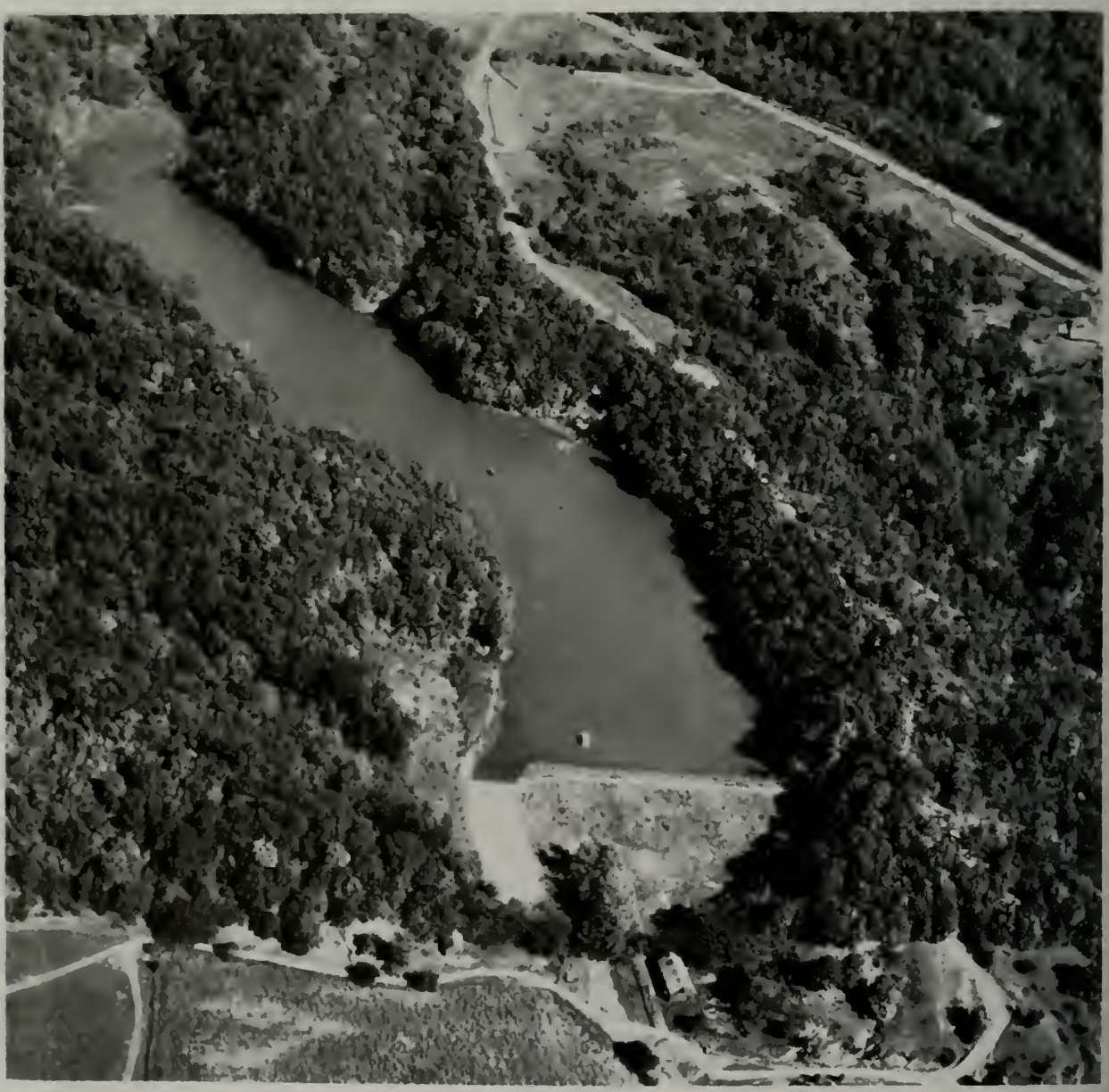

Fig. 1.-Ridge Lake, aerial view toward east. The dam, surface spillway, and tower spillway are at the lower end of the lake. The laboratory is visible within an indentation in the shore-line vegetation on the south bank of the lake. 
it was believed that, unless the numbers were greatly reduced, food competition would become severe and growth would be slow. Consequently, 335 yearling bass were introduced into Ridge Lake on June $18,19+1$. This introduction of yearling bass was ineffectual in thinning the numbers of bass fingerlings sufficiently, and, by $19+2$, bass of the $19+1$ brood had stopped growing.

In $19+3$, a culling technique, in which sinall or otherwise undesirable fish were permanently removed from the lake, as described in the section titled "The Draining Census," was adopted and used in alternate years to allow bass spawners to produce an abundant crop of young at intervals of 2 years. The culling technique allowed no single year-class to become dominant, because many large bass were present and actively preying upon the young as they reached fingerling sizes. This technique could be depended upon to assure the production of bass to replace those caught by anglers (who after $19+5$ were not restricted to the 10 -inch length limit for bass) and those removed with other small fishes in the biennial culling operations.

The present publication is essentially a description of the culling technique of management and its effect upon the largemouth bass in Ridge Lake for an approximate 10 -year period beginning with the spring of $19+1$ and ending after the bass spawning season but before the angling season of 1951. This technique, which is being employed in all recreational lakes built by the state of lllinois, may be depended upon not only to maintain good bass fishing over an indefinite period but to produce superior angling for fish of other warm-water species inhabiting these lakes.

\section{Acknowledgments}

Nearly everyone who has been employed on the permanent or temporary staff of the Aquatic Biology Section of the Illinois Natural History Survey since $19+1$ has assisted in some capacity in the Ridge Lake investigation. In the early years, Mr. Bruno von Limbach, Dr. Louis A. Krumholz, and Dr. Philip IV. Smith contributed much time to general collec- tions. On draining censuses, the staff usually consisted of six to eight individuals, and over the five censuses (19+3-1951) included Dr. Donald Hansen, Mr. von Limbach, Dr. Krumholz, Mr. Jacob H. Lemm, Mr. Daniel Avery, Mr. Paul G. Barnickol, Dr. Arthur IVitt, Jr., Mr. Leonard Durham, Dr. R. Weldon Larimore, Dr. IVilliam C. Starrett, Dr. James S. Jordan, Mr. IValter H. Hart, and Mr. William Nuess. Included among the several members of the staff of the State Department of Conservation who helped with these censuses were Mr. Sam A. Parr, Mr. William J. Harth, Mr. Glee Fogelman (deceased), Mr. James Holmes, Mr. Quentin Pickering, Mr. George Kuhn, Mr. Ora Price, and Mr. Bruce Muench.

As members of the staff of the Illinois Natural History Survey, several persons made special contributions to this study. Mr. Robert G. Rennels, Dr. Smith, Mr. Vernon A. Anderson, Mr. Charles D. Kemp, Mr. John Jedlicka, Jr., and Mr. IV. IV. Fleming took limnological samples and statistics on the anglers' catch. Mr. Frank C. Bellrose, Mr. G. H. Boewe, and Mr. Fleming made special studies on the flora of the lake. Dr. IVitt and Mr. Durham studied the growth of Ridge Lake bass and bluegills from scale collections. Mr. James S. Ayars edited the manuscript. The author fully acknowledges the assistance given by those listed above.

\section{Characteristics of Ridge Lake}

Ridge Lake, fig. 1, was constructed by damming Dry Run Creek, an intermittent stream flowing through a steepsided ravine within the boundaries of Fox Ridge State Park, 7 miles by road south of Charleston. The original area of the lake at overflow level in late $19+1$ was 18.1 acres. Water is supplied by drainage from 902 acres of the watershed of Dry Run Creek, which is a small tributary of the Embarrass River. Much of the land within the watershed of the Embarrass River in this immediate region is unusual in that medium slopes are rare; level lands break into steep-sided ravines with slopes of more than 30 per cent. In the Ridge Lake watershed, slopes of less than $t$ per cent are found on 64.6 per cent of the area; 
on 33.2 per cent of the area, slopes are in excess of 30 per cent (Stall et al. 1951: 20 ). Agricultural misuse of the watershed has created a serious silting problem within the lake. In 1949, Stall et al. (1951: 12) found that the lake had an average annual capacity loss of 1.29 per cent, representing an annual erosion of 4.36 tons of soil per acre of watershed.

The amount of soil loss from the watershed depends primarily upon the nature of the soils, slopes, and land use or farming practices. Erosion occurs in two forms, sheet erosion and gully or channel erosion. Pasturing of some of the ravines above the lake contributes to the erosion. The slipping of earth from ravine sides into the valley floor occurs even where the ravines are entirely unpastured. Most of the soil that drops off the hillsides as a result of slipping eventually comes to rest on the bottom of Ridge Lake. In 1950, about 4 acres of the upper lake area were covered with water of less than a foot in depth; this same area was covered with water 3 to + feet in depth when the water was impounded in 19+1. An effort is now being made to organize a soil conservation district that will include the lake watershed and that will slow down the rate of sedimentation within the basin.

The fill impounding the water of Ridge Lake is a 450 -foot earthen dam running north and south across the valley of Dry Run Creek; a concrete surface spillway 70 feet wide was constructed over a natural bank at the north end of the fill, fig. 2. 'The primary overflow structure, however, is a tower spillway designed so that it removes water from the bottom of the lake rather than from the surface. Inside the tower is a spillway wall parallel to the dam that divides the tower into an east and a west section; the overflow lip, the top of this wall, is 8 feet long; its elevation above sea level is 595 feet. The elevation of the crest of the surface spillway is 596 feet above sea level, so that, on small rises of the lake level, all the overflow water passes through the tower. As the tower is open at the bottom, water from the hottom of the lake rises in the east section of the tower to correspond to the lake level. When the lake level exceeds the overflow lip, the water spills over into the west section of the tower, the section nearer the dam, and passes through a rectangular concrete tunnel 5 feet wide and 7 teet high to that part of Dry Run Creek on the downstream side of the dam. In summer, when the waters of the lake are thermally stratified and the bottom waters are devoid of oxygen, rises in the lake level allow stagnant bottom water to escape from the lake.

A gate valve, + feet square, located at the base of the spillway wall in the tower, allows the lake to be drained. 'This gate was first closed on April 17, 1941, when construction of the dam was completed.

In 1940, a brick laboratory and a boat dock were constructed on the south shore of the lake about 800 feet up the lake from the dam, fig. 3. At the same time, two single-post concrete towers were built, one in the center of the lake opposite the laboratory and the second about two-thirds of the distance up the lake from the dain to the upper end of the basin. These towers, which were supplied with wooden floors and railings, have been used to support recording thermographs and other weather instruments.

The maximum lake depth, 25 feet, is in the old stream channel near the dam; the valley floor of the lake near the dam is 4 to 6 feet above the bottom of the old stream channel. From the old stream channel near the dam, the floor of the valley gradually rises until, about 2,500 feet up the lake from the dam, it exceeds the 595-foot level of the overflow lip of the tower spillway. The width of Ridge Lake varies from about +00 feet at the dam to 200 feet at the upper end. The steep side walls of the lake basin tend to make much of the lake comparatively deep, except in the upper end, where sedimentation is now extensive.

\section{Limnological Characteristics}

Limited work on the limnology of Ridge Lake defined the range of variation of some physical and chemical characteristics of this body of water during the summer periods of 19+1-1951, somewhat longer in $19+2$ than in the other years; some quantitative biological sampling was done in $19+8$ when Fleming (1949) was investigating the characteristic forms of plankton 
and bottom fauna associated with growths of rooted apuatic vegetation.

Throughuut the periods when biologists were stationed at the laboratory (summers, 19+1-1951), recording thermographs were operated to measure fluctuations of air temperatures and of water temperatures at various depths, fig. 4. Daily records were made of rainfall; these were compared with the fluctuations in water levels recorded on a continuous water level recorder and with changes in the transparency of the water as determined by Secchi disc readings. In $19+2$, when a biologist was stationed at the laboratory throughout the greater part of the year, analyses for dissolved oxygen were made on waters collected at frequent intervals from late February to the third week in October at depths of $0,3,6,9,12,15$, and 18 feet. Because physical and chemical data were collected for a longer continuous period of time in $19+2$ than in any other year, the records for $19+2$ have been used to illustrate the relationships between these data, figs. 5 and 6 . Fig. 5 show's the average weekly air temperatures and the average weekly water temperatures at a depth of + feet (by recording thermographs) from the third week in March through the greater part of October; also, water levels, transparencies of water, and rainfall for approximately this same period.

Rainfall, Water Levels, and Transparency.- The drainage basin of Ridge Lake is large in proportion to the capacity of the lake basin. This fact, coupled with the fact that most slopes in the drainage basin are steep and that some of them are overgrazed, insures a rapid runoff of rainfall carrying a relatively large load of silt, most of which passes into the upper end of the lake basin, where the heavier particles of silt are dropped. Fine clay particles disperse throughout the waters of

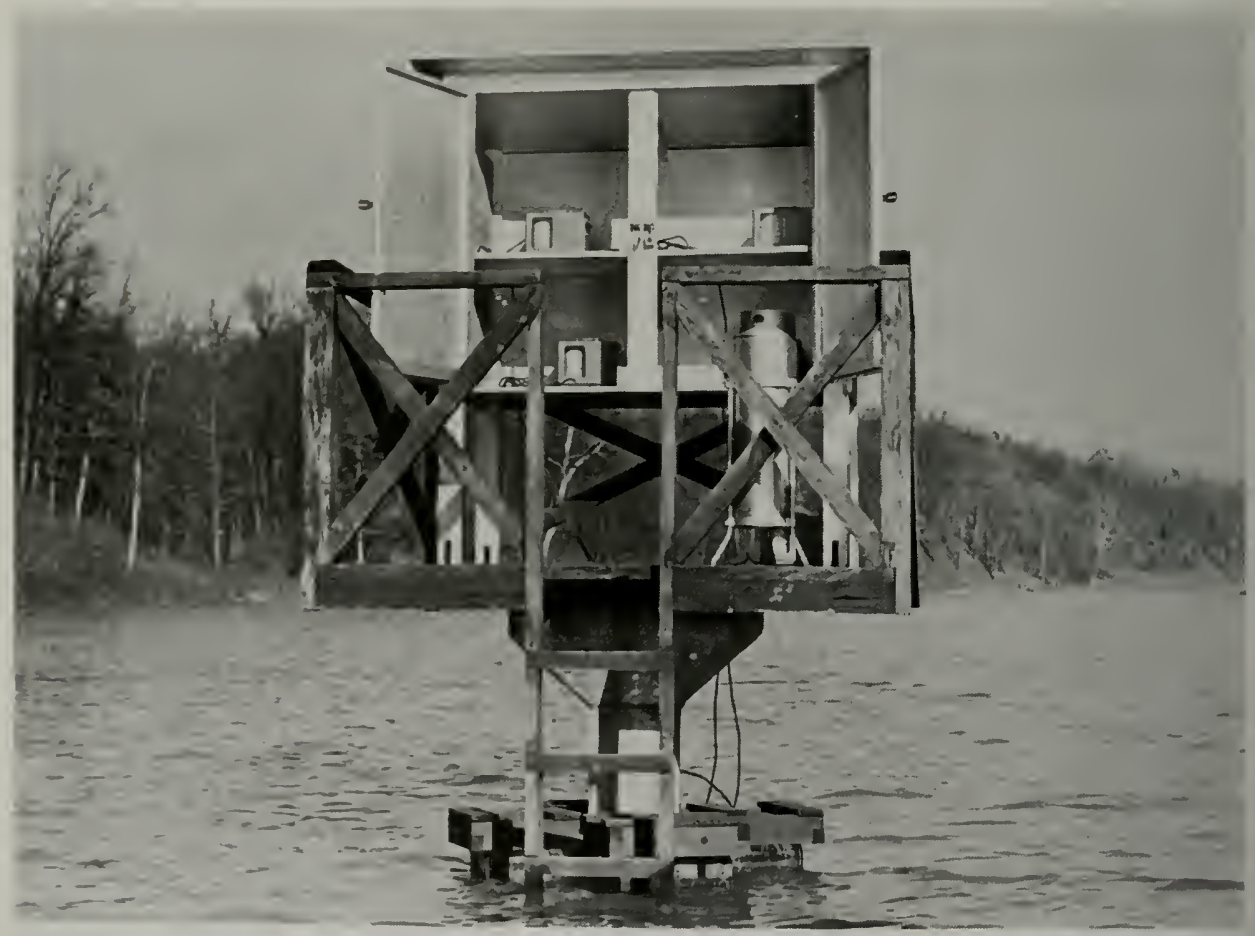

Fig. 4.-Recording thermographs on instrument tower in Ridge Lake opposite the laboratory. These thermographs were used to record air temperatures and water temperatures at various depths. The bulbs of water temperature recorders were suspended from a float built around the concrete lower so that they would rise and fall with changing lake levels. The rain gauge shown here, when in use, was placed on a second tower in the upper part of the lake. A water-level recorder was located on the boat pier in front of the laboratory. 
the lake and increase the turbidity. During periods between rains, these clay particles settle out, and the lake becomes clear.

In 19+2, the lake was most turbid on March 12, fig. 5, when a Secchi disc would disappear at 0.7 foot below the surface. Transparencies of less than 2 feet were recorded also on March 16, 19, and 22; on April 8, 9, and 10 ; on May 7 ; and on June $17,15,16$, and 17 . While all rains of as much as 0.5 inch influenced the transparency of the water to some extent, most rains of 1 inch or more were followed by periods of very low transparency of water, showing Secchi disc measurements of less than 2 feet. Such low transparency; during the fishing season, interfered with fishing success. Once the transparency approached 1 foot, about 5 or 6 days free from rain were required for the water to reach a maximum of transparency.

The amount of silt entering the lake and the muddiness of the water varied not only with the condition of the vegetative cover on the watershed (influenced by the seasons) but also with the type of rainstorm. For example, on June 26, 19+2, a rain of 2.0 inches was recorded as having fallen throughout a period of 10 hours; transparency readings made on that day and on days following showed that the lake had greater transparency on the first and second days after the rain than on the day of the rain. In another instance (September $19,19+2)$, a violent rain of short duration amounting to only 0.65 inch caused a drop in transparency from 10 feet to 3.7 feet, apparently without raising the water level of the lake.

The maximum transparency of the water was measured at $1+$ feet on June $t, 19+2$, after 15 days of little or no rainfall. Later, in the summer and fall of the same year, water transparency did not exceed 10 feet. During this period, the transmission of light was reduced by plankton (mostly blue-green algae) rather than by particles of clay.

In 19+2, the water level of Ridge Lake never dropped lower than $0 . t$ foot below the overflow lip of the tower spillway. The drainage basin of $1 .+1$ square miles (902 acres, or about 50 acres of drainage basin per acre of lake) is large enough to fill the lake basin with runoff water from normal rainfall several times during a single year. Even in late summer, a time of infrequent rains, the runoff is sufficient to prevent severe drops in the lake level.

The tower spillway, fig. 2, which removes water from the bottom of the lake, has a capacity of 25 cubic feet of water per second. If the water inflow from the drainage basin exceeds this capacity, the level of the lake rises and, if the lake level exceeds the crest of the surface spillway, a foot higher than the lip of the tower spillway, the water flows over into a stilling basin and then into the section of Dry Run Creek below the dam. The capacity of the surface spillway is so great that runoff waters from even the heaviest rains do not create a flow of water exceeding about a foot in depth on the crest of this spillway. Within a matter of minutes after a rain, or at most a few hours, the lake level drops below the crest of the surface spillway.

In 19+2, the water level of the lake rose above the crest of the surface spillway eight times, fig. 5, after rainfalls of approximately 1 or more inches. Water continued to run out of the lake through the tower spillway all through the spring and summer until August 22. On September $S$, a rain of 2.2 inches, which feli during a period of 12 hours, raised the water level in the lake 0.7 foot, and water again flowed through the tower spillway. The maximum fluctuation of the lake level throughout the spring, summer, and fall of $19+2$ was 2.5 feet.

Thermal Stratification and Dissolved Oxygen.-Ridge Lake would probably show characteristics of a eutrophic lake except for the occasional loss of substantial quantities of water from the lower strata following heavy rains. As mentioned previously, an inflow of runoff water from the lake watershed in amounts large enough to cause a significant rise in the lake level above the lip of the tower spillway is followed by a loss of water through that outlet from the cold, oxygendeficient stratum immediately above the lake bottom. Except after rains so heavy that water flows over the surface spillway, the volume of bottom water lost is approximately equivalent to the volume 


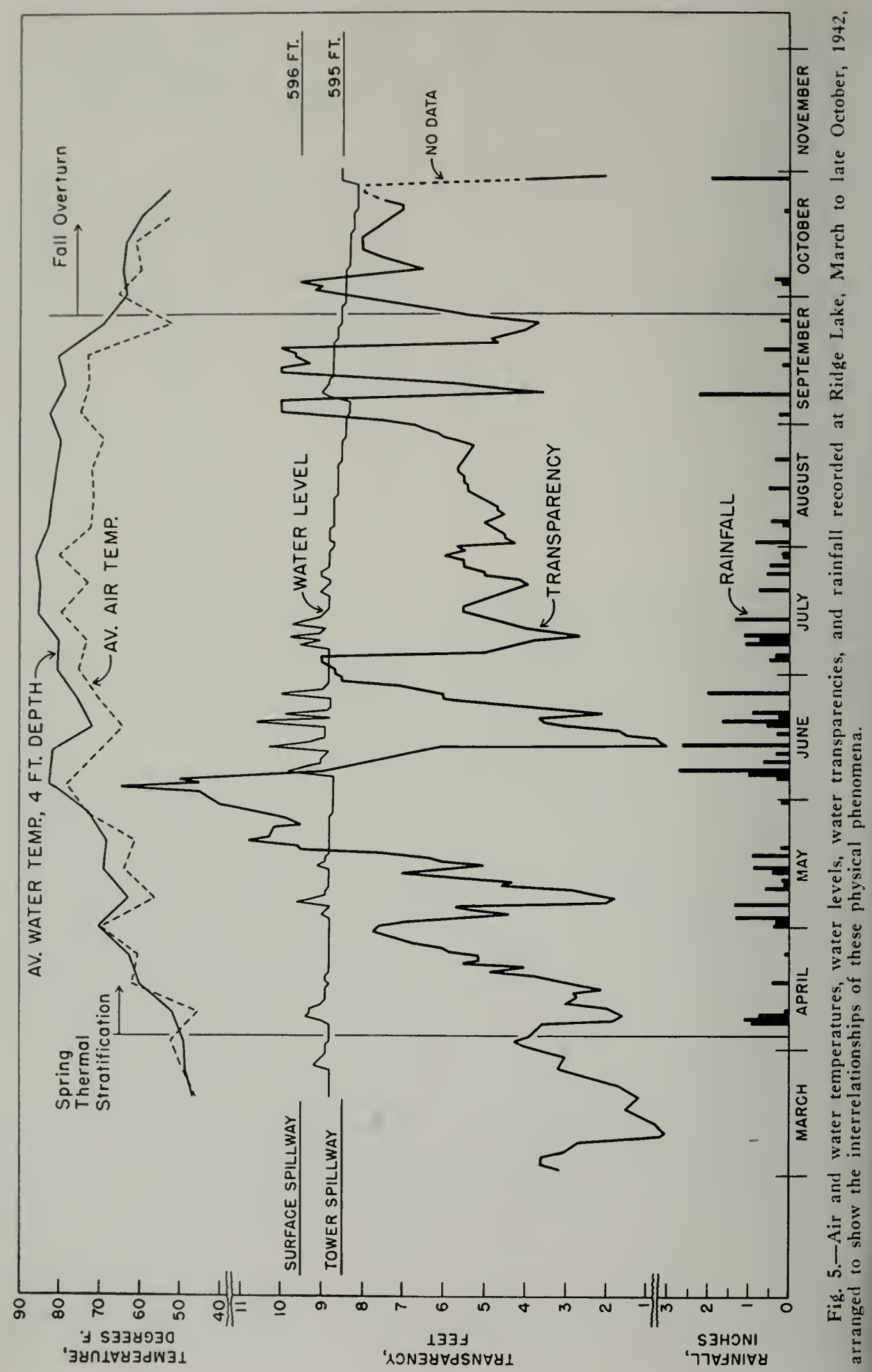


of runoff water flowing into the lake. After large rains, this exchange of water is extensive. Most of the runoff water, when warmer than the bottom water, flows from the upper end of the lake toward the lower end at surface or nearsurface levels. The bottom water is replaced by water from strata lying immediately above; the lowest and coldest layers are lost through the tower spillway. The magnitude of change (increase) in the temperature and dissolved oxygen content of waters in the bottom strata of the lake following a period of rainfall is dependent upon the volume of runoff water draining into the lake from the watershed. When the volume of runoff water is great enough to exceed the capacity of the tower spillway and raise the lake level above the crest of the surface spillway, the water discharge from Ridge Lake becomes a combination of surface water and bottom water.

In $19+2$, persistent thermal stratification of Ridge Lake, characteristic of the warm seasons, began on April t, figs. 5 and 6. Prior to this date the lake appeared to be thermally stratified for short periods; in each of these periods, the stratification was broken up by cold weather. which usually was accompanied by heavy rainfall.

Annually, during the period of summer thermal stratification, Ridge Lake shows a surface layer of warm water (epilimnion) of 3 to 5 feet in thickness. In the thermocline, the layer of water below the epilimnion, the temperatures gradually become lower toward the bottom. The thermocline may show a temperature gradient of 10 to 18 degrees F. within a perpendicular distance of only 18 feet. No indication is given of a hypolimnion, or stratum of water of uniform temperature lying directly above the lake bottom.

Early in April, 19+2, the temperature of the water at a depth of 18 feet was t6.5 degrees $F$., while the temperature of the water at the surface was 59.0 degrees $F$. Between the first week in May and the first week in June, the temperature at 18 feet rose from 50.0 to 63.5 degrees F. while that at the surface rose from 70.5 to 87.0 degrees $F$. The maximum temperatures for the 18 -foot depth during the latter half of July and throughout August in $19+2$ ranged from 71.7 to $7+.0$ degrees F. During this same period, surface temperatures varied between 80.0 and 88.0 degrees $\mathrm{F}$.

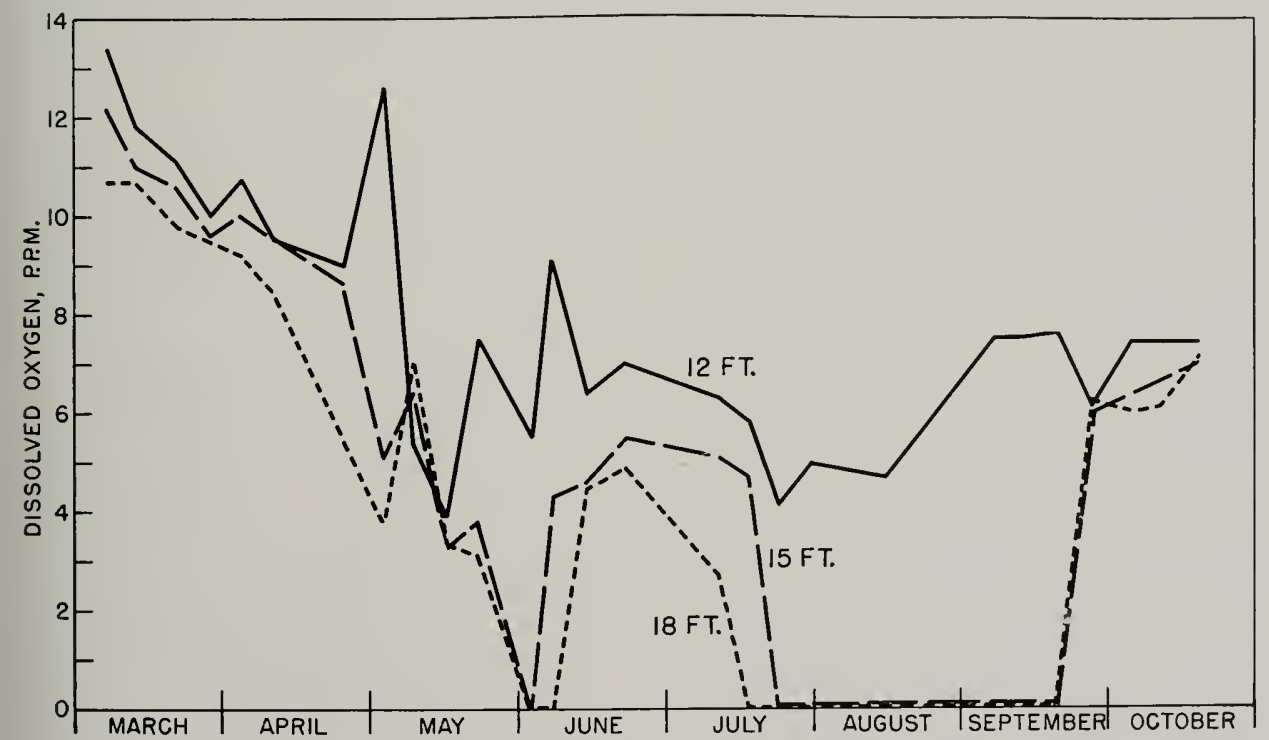

Fig. 6.-Dissolved oxygen, parts per million, at 12-, 15-, and 18-foot depths in Ridge Lake, early March to late October, 19+2. The rise in oxygen during the month of June was due to the replacement of stagnant bottom water forced out of the lake through the spillway tower by surface water entering the lake from rains that fell on the watershed. 
'Throughout the entire period of stratification there was at least 0.5 degree difference hetween temperatures at 15- and 18 -foot depths and at least 1 degree difference between temperatures at 12- and 15-foot depths. Usually the differences were 1 to 3 degrees between the 15- and 18 -foot depths and 1.5 to + degrees between the 12- and 15-foot depths.

The first period of rapid increase of water temperatures at the 15- and 18-foot depths occurred in early May following heavy rains of $M$ May 3 and 6 . At the heginning of this period, the temperatures at the 15- and 18-foot depths were 51.0 and 50.0 degrees $F$, respectively. By early June, the temperatures at the 15- and 18foot depths had risen to $6+.0$ and 63.5 degrees $F$., respectively. By June 7 , when rains were resumed after a period of very low precipitation, temperatures at the 15 and 18 -foot depths had dropped to 61.0 and 58.0 degrees F., respectively. Heavy rains occurred at rather frequent intervals from June 7 to July 14 , and during this period the temperature of water at the 15 -foot depth rose from 61.0 to 72.0 degrees $F$. and at the 18-foot depth from 58.0 to 70.5 degrees F. During this same period, the temperature of the surface water dropped from a high of 87.0 degrees $F$. on June 2 to 82.5 degrees $F$. on July 14.

The fact that periods of rapid temperature rise in the water close to the lake bottom corresponded to periods of heavy rainfall indicated that the loss of the cold bottom water through the spillway tower was largely responsible for these temperature increases.

Fluctuations in the dissolved oxygen content of the deeper waters of Ridge Lake were even more striking than those in temperature. Following the beginning of prolonged stratification in April, 19+2, the supply of dissolved oxygen at the 15and 18-foot depths gradually became less, except when, during the second week in May, two rains, each exceeding 1 inch of precipitation, fig. 5, apparently forced out of the lake a large volume of the bottom water containing a reduced supply of dissolved oxygen. 'This water was replaced by that lying nearer the surface and containing a greater amount of oxygen. Thus, there was a temporary in- crease of oxygen at the 15- and 18-foot depths; but, beciuse of the oxygen demand of organic material on and above the lake bottom, the new supply rapidly was used up until by early June no dissolved oxygen remained. On June 7 , a period of heavy rainfall began, fig. 5, which ended July 1+; there were 7 consecutive days (last $t$ days in June and first 3 days in July) when no rain fell. The heary rains of this period forced the oxygen-deficient waters out of the lake and almost immediately increased the available dissolved oxygen to more than + parts per million at the 15-foot depth and considerably more at the 12 -foot depth, fig. 6 . Samples for oxygen analyses taken at these depths and at the 18-foot depth (this sample was taken 8 inches off the bottom) on July 11 showed that the dissolved oxygen was 6.3 p.p.m. at 12 feet, 5.1 p.p.m. at 15 feet, and 2.7 p.p.m. at 18 feet. Before the end of the third week in July, the dissolved oxygen at 15- and 18-foot depths had again dropped to zero, where it remained until the fall overturn began on September 27, as a result of abnormally cold weather during the preceding week. At the time the fall overturn began, water temperature at a depth of + feet was 62.0 degrees $F$.

'The biological effect of the removal of stagnant water from the lower levels of Ridge Lake is unknown. Certainly it must temporarily increase the volume of water inhabitable by fish. Evidence from oxygen determinations made in $19+8$ by Fleming $(1949: 20)$ and by other workers in $19+2$ and $19+3$ shows that, after periods of flushing, the increased oxygen supply is rather rapidly used up, probably too soon for the invasion of those bottom organisms that require dissolved oxygen. The increase in water temperatures may speed up the growth of midge larvae (Chaoborus) that normally inhabit oxygen-deficient bottoms. It is probable that the perpendicular extent of the oxygendeficient stratum of water above the bottom is, on the average, somewhat less than it would be without the tower spillway arrangement for loss of bottom water.

Fertility of Water.-Ridge Lake probably ranks intermediate in fertility when compared with other lakes within the boundaries of Illinois. Judged by fish production, most ponds and lakes in central 
and northern Illinois are more fertile and many in southern Illinois are less fertile (Bennett 19+3:361 and unpublished fish censuses of ponds and lakes). Comparisons of the mineral analyses of the water of several Illinois lakes, and the poundages of fish these lakes support, with measurements of soil fertility on the watersheds show that a large part of the nutrient materials of each lake may have entered the lake with runoff water from the watershed and become trapped within the basin. A part of these materials may be buried under silt deposits. In addition to the nutrients that enter from the watershed, there is within the lake itself an accumulation of organic materials resulting from the death and disintegration of plants and animals, all of which adds to the fertility. More nutrients and organic matter are gained through inflowing water and through accumulation than are carried away in overflow, and thus impoundments, many of which are built over soils of comparatively low fertility, tend to become more fertile as they age.

Table 1 shows two partial mineral analyses of water made by the Illinois State Water Survey: one of the water of Dry Run Creek prior to impoundment and a similar one of lake water after impoundment. A comparison of these two analyses shows large differences in the

Table 1.-Partial mineral analysis of water from Dry Run Creek, April 7, 1938, prior to impoundment, and of water from Ridge Lake soon after gate valve was closed, April 22, 1941.

\begin{tabular}{|c|c|c|}
\hline Mineral & $\begin{array}{c}\text { DRY RUN } \\
\text { CREEK, } \\
\text { April } 7,1938, \\
\text { PARTS Per } \\
\text { Million }\end{array}$ & $\begin{array}{l}\text { RIDGE LAKE, } \\
\text { APRIL 22, 1941, } \\
\text { PARTS PER } \\
\text { MILIION }\end{array}$ \\
\hline 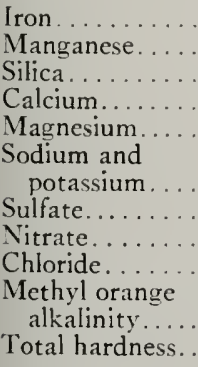 & $\begin{array}{r}2.0 \\
0.0 \\
21.0 \\
5.2 \\
24.3 \\
\\
59.6 \\
18.5 \\
1.2 \\
1.5 \\
220.0 \\
113.0\end{array}$ & $\begin{array}{r}3.2 \\
0.5 \\
9.5 \\
72.1 \\
22.9 \\
11.0 \\
40.1 \\
1.8 \\
5.0 \\
248.0 \\
2720\end{array}$ \\
\hline
\end{tabular}

amounts of almost all of the minerals. These two water samples were taken approximately 3 years apart, and during this length of time changes may have taken place in land use within the watershed, opening up new areas to erosion and leaching.

A study of Ridge Lake (Stall et al. 1951:2t-5) showed that a large part of the sediment deposits of the lake originated probably from the Hennepin gravelly loan which occurs on the steep, heavily eroded slopes of the watershed. These deposits contain amounts of potassium and phosphorus adequate for farm crops, but they are low in nitrogen.

The soils of the flat uplands of the Ridge Lake watershed are planted usually to row crops-corn and soybeans. These soils are much less fertile (judged on the basis of the crops they produce) than are most of those farther north in Illinois; while the northern soils average a cornproduction rate of approximately 75 bushels per acre, those in the region of Dry Run Creek average not more than 25 bushels per acre.

Growing Season for Fishes.-In experiments with largemouth bass, Markus (1932:210) found that the rate of digestion was very slow in fish held in water below 50 degrees $\mathrm{F}$., but that it increased rapidly with increasing temperatures up to about 72 degrees F. Observations on growth of the largemouth bass in Illinois ponds indicate that growth begins each spring when water temperatures range between 50 and 60 degrees $\mathrm{F}$. Average water temperatures at the 4 -foot depth in Ridge Lake in 19+2, fig. 5, first exceeded 55 degrees $F$. during the week of April 13-19 (April 15) and did not again drop to 55 degrees F. until the week of October 27-November 2 (October 29). These temperature readings showed that the growing season for bass at Ridge Lake was nearly 6.5 months long in $19+2$. Similar measurements of water temperatures in Fork Lake (Bennett, Thompson, \& Parr 1940:13, 15) in 1939 showed that the growing season in this pond was 6 months. The site of Fork Lake, which lies within 65 miles of Ridge Lake, is only about 25 miles farther north, and its seasonal cycle of temperatures probably is comparable to that of Ridge Lake. 
There is evidence that in $19+2$ the growing season at Ridge Lake hegan unusually early. 'The average weekly water temperatures (at + feet) of 62.6 degrees F. recorded for the week of April 20-26, 70.2 degrees I: for April 27-May 3, and $\$ 2.5$ degrees $F$. for June $1-7$ are unusually high for these times of year, fig. 5 . Further, the first schools of bass fry in $19+2$ were seen on May 14 and the maximum number of schools was counted on May 19. In all other years except 19+1 and 1951, schools of bass fry were not in evidence until after June 1. For these reasons, we considered that the $19+2$ season was abnormally long. In most years of this study, the growing season at Ridge Lake did not exceed 6 months.

Aquatic Plants.-A large number of marsh and moist-soil plants were to be found growing along Dry Run Creek before Ridge Lake Was built. In March, $19+1$, prior to the closure of the gate valve in the dam, G. H. Boewe and Frank C. Bellrose of the lllinois Natural History Survey staff collected plants in the lake basin and reported on the species to he found there. Among the marsh plants were the following:

Bulrush, Scirpus atrozirens IVilldenow and Scirpus, probably polyphyllus Vah!

Common cattail, Typha latifolia Linnaeus

Horsetail, Equisetum sp.

Sandbar willow, Salix interior Rowlee Sedges, Carex spp.

Virginia wildrye, Elymus rirginicus Linnaeus

Early in the period of impoundment, from April, 19+1, until midsummer, 19+2, little aquatic vegetation was in evidence, although cattail, American waterplantain, Alisma subcrordatum Rafinesque, horsetail, and some sedges had appeared at the upper end of the lake. Leafy pondweed, Potamogeton foliosus Rafinesque, was collected in several places in the upper end of the lake on September 5, 1942, and by September 15 it was becoming abundant.

In 1941 and subsequent years, any cattails that appeared were cut off at the roots. Consequently, in the years that the lake has existed, these plants have never increased in abundance beyond a few scattered individuals.
Scattered bunches of Potamogeton foliosus were growing in the shallows in front of the surtace spiltway and in the upper end of the lake in early June, 1943. By August, lense mats of fine-leaved potamogeton were abundant in water up to 6 feet in depth, and scattered bunches of $P$. nodosus Poiret, sago or fennelleaf pondweed, $P$. pectinatus Linnaeus, cattail, waterplantain, and several species of arrowheads, Sagittaria spp., including common arrowhead or duck potato, $S$. latifolia Willdenow, were growing in shallow water.

In $194+$ and $19+5$, the vegretation wass essentially of the same species as those found in 19+3; in addition, the naiad, Najas flexilis (Willdenow) Roskovius \& Schmidt, and Canada waterweed or elodea, Anacharis canadensis (Michaux) Planchon, were first collected in 1945.

In 19+6, a vegetation die-off occurred for the first time in Ridge Lake. A similar die-off, which occurred each year from $19+6$ on, usually had begun by the tenth of July: A coating of blue-green algate seemed to envelop the plant mats, which began to sink in some places, forming deep ravines of open water between ridges of dying plants. These open-water areas gradually increased in extent until much of the lake that had been choked with vegetation in June was open water by the end of July.

In 1948, when among the most abundant plants were sago pondweed and elodea, these plants completely disintegrated within 2 weeks of the time they were first observed to be affected (July 8 ). Dragging a garden rake on parts of the lake bottom, where the thickest mats had been, produced only wisps of decaying plant stems. By July 23, the entire lake was open water except for small beds of elodea in shallow water at the upper end of the lake and at the surface spillway. These were second-growth plants, as the original plants had died there also. Both sago pondweed and elodea gradually cane back, until by August 25 the plants had grown to the surface again in much of the area formerly filled with them. However, the growth was not so thick as the first growth had been.

In 1949, when the lake refilled only to about the 11 -acre contour after the March 
draining, the mats of aquatic vegetation and the midsummer die-off were similar to those of preceding years except that, with the shallower water, the beds were farther down the lake toward the dam. $\mathrm{By}$ August 5, the exposed bottom of the upper end of the lake was grown up shoulder-high with smartweed and rice cutgrass, Leersia oryzoides (Linnaeus) Swartz. The upper end of the lake was not again reflooded until late November.

The plant cycle of 1950 was similar to that of $19+8$.

Fleming (1949) studied the dissolved oxygen content, carbon dioxide content, and plankton of the water within the mats of vegetation and compared the data he obtained there with similar data from open water. He found a daily oxygen cycle in the plant mats, in which the dissolved oxygen reading usually was highest in the early afternoon and lowest at about 5 A.M. (Fleming 19+9:18-9). Entomostraca and rotifers were less common in the vegetation than in the open water, but the plant mats, particularly of elodea, harbored considerable food for small fishes.

The mats of plants in the upper end of Ridge Lake harbored unknown numbers of small fish (usually both bass and bluegills) that appeared to stay within the plant-growth area throughout the entire summer season. These fish made poor growth; some bass fingerlings collected in this part of the lake in September, 1948, were less than 2 inches in length, although 3.5 months of age. The midsummer dieoff of aquatic plants probably reduced the number of small fish living within the confines of the vegetation by forcing these fish into open water at a time when they could be utilized by larger bass. Thus, the July die-off of vegetation was probably a wholly desirable phenomenon from the standpoint of fish management.

\section{The Creel Census}

Ridge Lake was first opened to public fishing in June, 19+2, and, with the exception of 1943, it has been opened each year since, under a system designed to give a complete record of all fish caught, the time spent in fishing, and the types of gear and kinds of bait used.
In most years of this study, the opening date for fishing was in June, as soon as possible after the bass fry were actively schooling, and the lake was kept open until August 31. Exceptions were in 19+2, when the lake, opened to fishing in June, was kept open until October 31; in 19tt, when the lake was opened on August 9 and closed on October 1; and in 1946, when the lake was opened on Saturday and Sunday of each week from April 6 until June 1, when it was opened for 5 days each week.

Except as noted above, public fishing periods were from 6 to $10 \mathrm{~A} . \mathrm{M}$. and from 3 to 8 P.N., Wednesday through Sunday of each week. The lake was closed on Mondays and Tuesdays. All fishing was done from seven boats owned by the Natural History Survey; for use of the boats no rental charge was made. The demand for these boats was so great that usually it was necessary for fishermen to make reservations for them in advance by mail or phone, particularly early in the season. Requests for boats during the first few days of the season were filled by drawing names from among those of the many applicants.

Fishermen coming from distances greater than 25 miles were allowed to reserve boats for both the morning and afternoon periods of any day on which they were permitted to fish. 'Those driving distances of less than 25 miles were limited to either a morning or an afternoon period of any day for which they were given permits. No bank fishing was allowed, because such fishing would have made impossible the collecting of complete fishing records and because the banks bordering the lake are very steep and the control of bank erosion was and is a problem difficult of solution.

All boats were stationed at the pier or boat dock immediately below the laboratory. Before each fishing period, fishermen having reservations for that period were checked in at this pier, where each submitted his state fishing license in return for a Ridge Lake fishing permit. On each permit were recorded the fisherman's name, his address, and the time of day when he began fishing. At the end of the fishing period or sooner, if he became tired, the fisherman returned to the pier, 


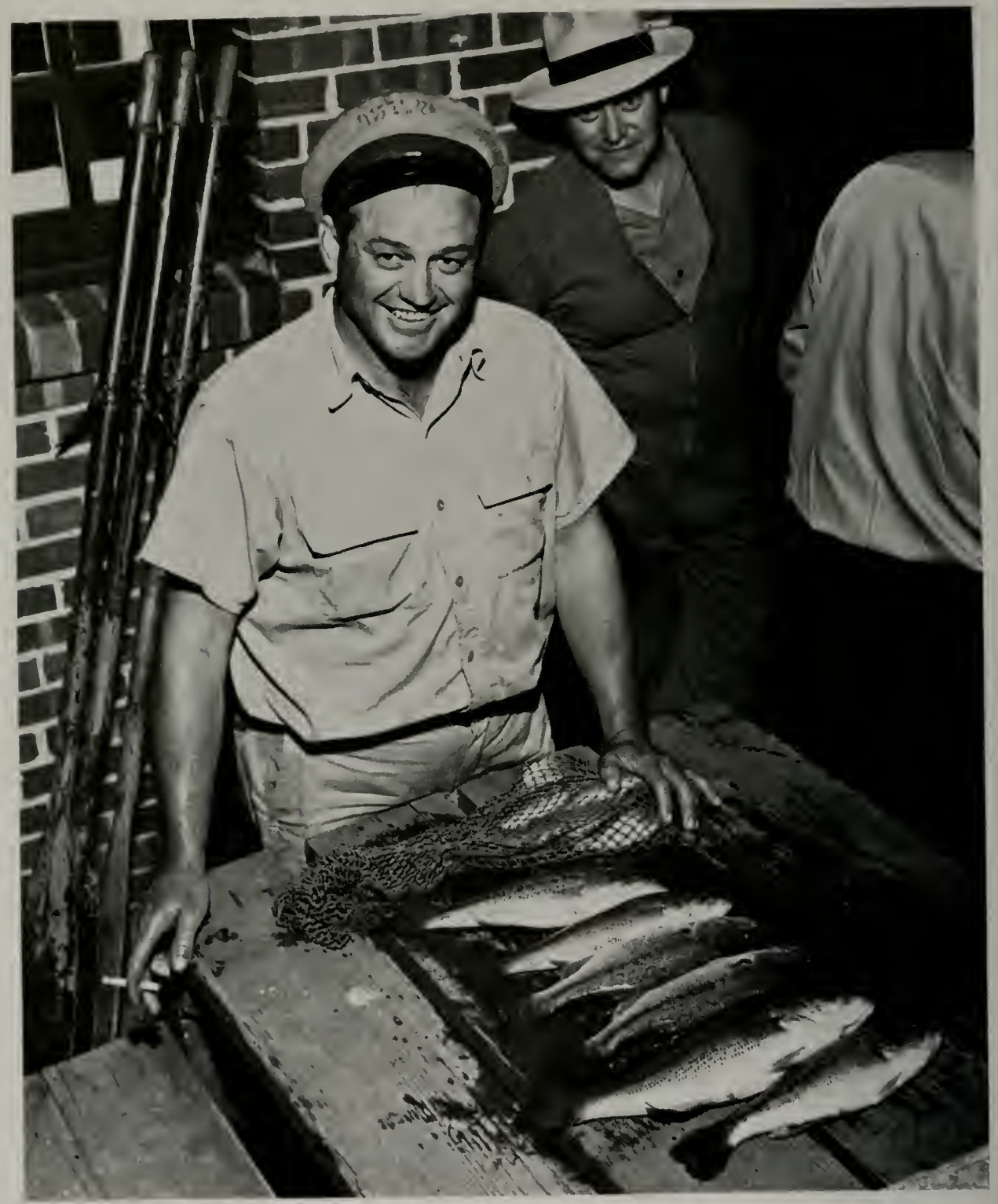

Fig. 7.-Ridge Lake fisherman with his catch arranged for the rapid taking and recording of pertinent data. As anglers brought in their catches, the length, weight, and fin-clip mark of each fish were recorded by an employee of the Illinois Natural History Survey. A sample of scales from each fish was taken for age determination, and a record was made of time spent in fishing and kinds of bait on which the fish were caught.

fig. 7, where the time of day was recorded on his lake fishing permit card. 'The fisherman was questioned about the baits and tackle he used, and the information obtained was recorded on the permit card. If the fisherman had brought in fish, these were weighed and measured, and a few scales from each were taken for later use in studies of age and growth rates. The scales from each fish were placed in a small envelope, and the length and weight of the fish were recorded in appropriate 
spaces on the outside. Any fin mark (clipped fin) was noted, both on the fishing permit card and on the scale envelope. After all pertinent data were recorded, the fisherman was given his state license and the legal-sized fish of his catch and allowed to make a future reservation. Fishermen were very co-operative, once the system was known, particularly those who lived within a radius of a few miles and fished the lake often.

Previous to 1946 , fishermen were not allowed to take largemouth bass of less than 10 inches. But in $19+6$ and following years, they were asked to bring in all bass, as well as all bluegills, they caught, regardless of sizes. Bass of less than 10 inches in length were not considered in a fisherman's limit of 10 legal-sized fish; so that a fisherman was allowed to catch and bring to the boat dock 10 legal-sized bass and any number of illegal-sized ones. The bass of less than 10 inches in length were left with the census taker at the boat dock. No creel limit was placed on bluegills, but no one fisherman ever exceeded the Illinois Fish Code limit of 50 in a single day. Since July 1, 1939, there has been no length restriction on bluegills taken by fishermen in Illinois.

Prior to $19+5$, the use of live minnows for bait was prohibited by regulation at Ridge Lake. This regulation, the object of which was to prevent the introduction into the lake of undesirable species of fishes, resulted in much dissatisfaction among fishermen. In 1945, and thereafter, fishermen were allowed to fish with live minnows after their minnow buckets had been inspected at the boat dock for young carp, suckers, and goldfish, which were removed when found.

The periods in which the lake was open to public fishing during the years 1942 through 1950 (this report does not extend into the 1951 fishing season) were as follows:

19+2-June 17 through October 31 (5 days a week, but fishermen were present on the lake on only 15 days in September and October)

$19+3$ - No public fishing

1944-August 9 through October 1 (5 days a week)

19+5-June 20 through August 31 (5 days a week)
19+6-April 6 through August 31 (week-ends, 2 days a week, during April and May; 5 days a week in other months)

1947-June 11 through August 31 (5 days a week)

1948-June 10 through August 29 (5 days a week)

19+9-June 15 through August 31 (5 days a week)

1950-June 15 through August 31 (5 days a week)

\section{The Draining Census}

In March of 19+3, and thereafter at intervals of 2 years $(1945,1947,1949$, and 1951), Ridge Lake was drained, the fish population was censused, and selected fish were fin-clipped and returned to the lake as soon as a sufficient amount of water had collected behind the dam. Through such an operation, the population was culled of small or otherwise undesirable fish. Draining was usually done during the latter part of March, when the water was cold and fish could be handled with little or no loss. In most years, spring rains could be counted upon to refill the lake basin within a few weeks, often before the exposed bottom had had sufficient time to dry out below a surface crust. Only in 1949, when local spring rains were less than normal, did the lake fail to refill by May 15 , following a March draining. In that year, the water covered an area of about 11 acres on June 1 and remained practically constant until November.

For the 19+3, 19+5, and $19+7$ censuses, a temporary fish screen was built, about 100 yards below the dam, across the section of Dry Run Creek that served as the outlet channel for the lake, fig. 8 . This screen was made of 1-inch-mesh poultry netting, two f-foot widths long enough to extend across the outlet channel. The two t-foot widths were overlapped 1 foot on one edge and fastened with small hog rings to make a single strip of netting 6 feet wide. One edge of the netting was supported 3 feet above the stream bed on steel fence posts driven at intervals across the stream channel; the free or lower edge of the netting was brought well upstream from the posts and staked in the bottom of a 1-foot trench 
dug across the channel. Then the trench wass filled with gravel, which buried the lower edge of the netting so deep that it would not pull loose.

On all censuses, the stilling basin at the base of the concrete surface spillway was used for holding fish to he returned to the lake. Weep holes in a $t$-foot header wall across the lower end of this basin were plugged, and the basin above the the valve open usually 18 to 24 inches and with frequent closing of the valve for cleaning the screen. The valve was never left open at night or when it was unattended.

When the lake level was down 12 to 15 feet, fish came through the outlet valve in small numbers; it was not until the lake level was down 18 to 20 feet that the fish came through in quantity. When

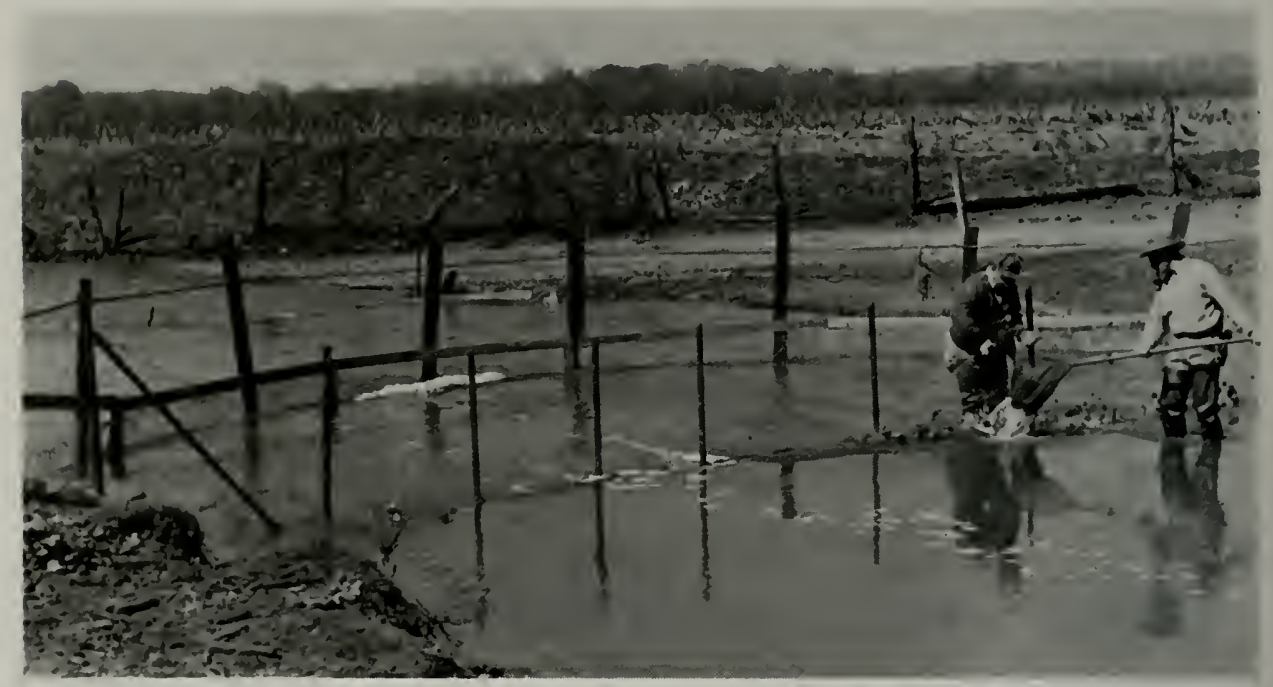

Fig. 8.-Temporary fish screen used in draining censuses. For fish censuses in $19+5$ and $19+7$, a temporary screen constructed of 1 -inch-mesh poultry netting was installed across the stream channel below the outlet of Ridge Lake.

wall was pumped full of water from the lake before any water was released through the outlet valve.

'Through tests run in the first two draining operations, it was discovered that no fish came through the outlet valve until the lake level had been lowered more than 10 feet (lake depth 25 feet from the spillway crest to the bottom of the outlet). As the valve gate is + feet square, the lake probably could be drained in 24 hours with the valve wide open. However, the flow resulting from a wide-open valve would top almost any screen that could be built across the stream channel and cause erosion of the stream banks below the outlet. The most the valve was ever open in actual draining operations was 36 inches and then only for a matter of minutes. Draining of the lake was accomplished in about $t$ or 5 days with the lake level was down about 18 feet. the valve was opened for a few minutes, and then closed while the fish that had come through were being handled. Fish to be saved for restocking the lake were separated out and moved immediately into the spillway stilling basin. 'Those of value for stocking new lakes and ponds were weighed, counted, and placed in a tank truck. All other fish were sorted by species and sizes, and representative samples were weighed and measured individually; the rest were weighed in groups of 100 to 200 and counted. When all or most of the water, except that constantly running in the stream channel, had flowed out of the lake basin, the valve was closed, and water was allowed to collect behind the valve for an hour or so. The water was then released, and usually more fish were washed through with it. This pro- 
cedure was repeated four or five times, until no more fish came through. In the meantime, a crew of several men walked over the lake basin to collect fish that had become stranded.

As the temporary screen described above was located 100 yards below the lower
While the tunnel was being built, runoff water was flowing in the natural stream channel across the dam site. After the concrete tunnel had been completed and before any clay was moved to the dam site for the fill, a diversion ditch was dug between the upper end of the concrete

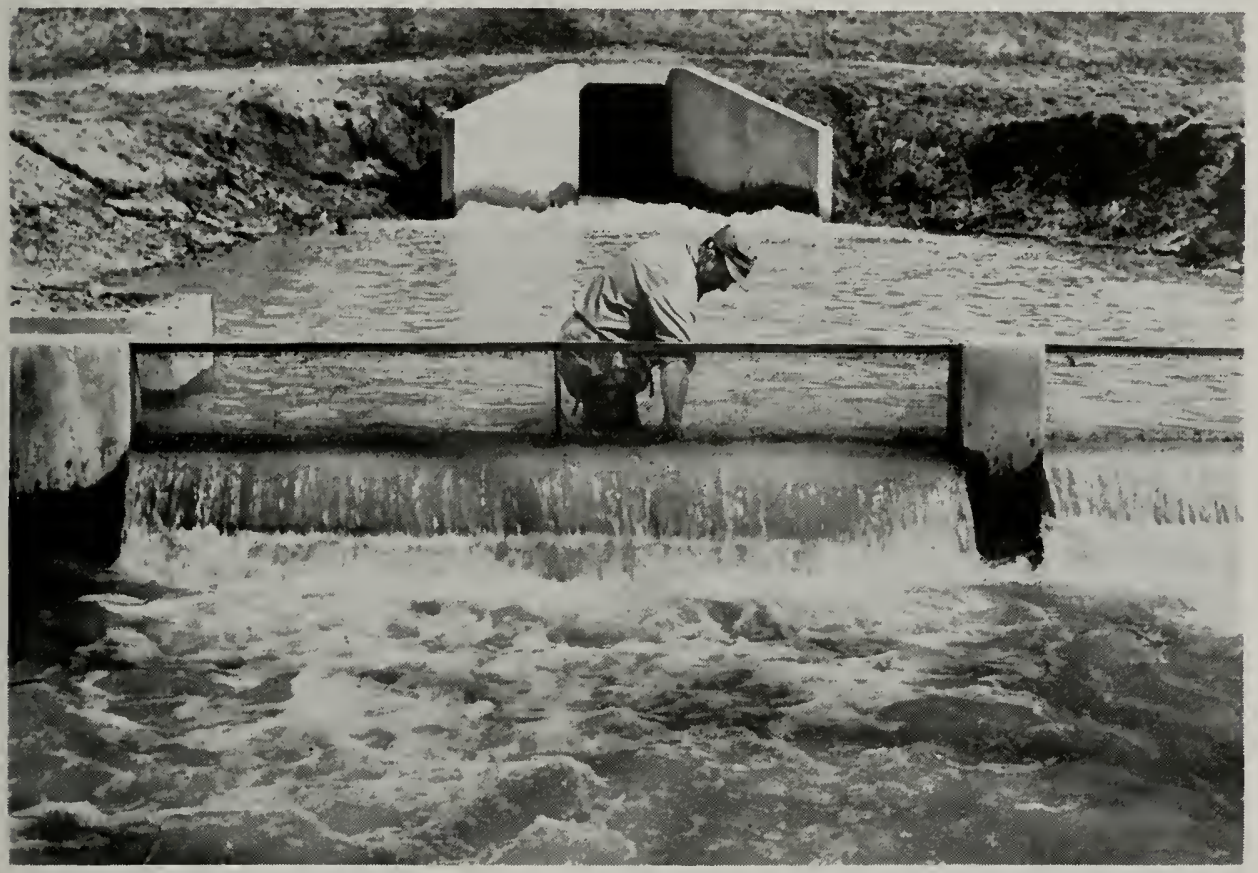

Fig. 9.-Improved type of fish screen used in draining censuses. A permanent screen was built below the outlet of Ridge Lake in $19+8$. It consisted of a wide concrete base, wing walls, and a center post double slotted to hold removable screen frames and planks. Planks placed below the screen frames created a head of water in the basin between the outlet and the screen and reduced the water pressure on the screen if the latter became partially clogged with debris. Screen frames could be raised for cleaning.

end of the outlet tunnel, on each draining operation several pools in the stream channel between the lower end of this tunnel and the screen had to be pumped out and the fish collected. In $19+8$, a permanent concrete base and slotted posts to hold removable screens were built only a short distance below the lower end of the outlet tunnel, so that the 1949 and 1951 draining and censusing operations were simplified, fig. 9.

The concrete outlet tunnel had been poured before the dam was constructed; it was located in an excavation near the opposite end of the dam site from, and parallel to, the natural stream channel. tunnel and the stream channel, to enter the latter about 150 rards above the dam site. The stream flow was then directed through the diversion ditch to the concrete tunnel, and the dam was built across the stream channel, leaving a blind channel or ditch (the old stream channel), about 100 yards long and several feet across, between the head of the diversion ditch and the dam. This hlind channel was never filled in and still contained 5 inches of water when the rest of the lake basin was drained in 19+3; it was believed to have been the hiding place of an estimated 473 small bass that escaped the first census, 87 of which appeared in 
$19+3$ as unnarked fish (see page $2+1$ ). Attempts to seine this ditch were futile hecanse of the hip-deep mud.

By the time of later drainings (19+5, $19+7,19+9$, and 1951), silting and sloughing-off of the banks had reduced the depth of water in this blind channel to 3 inches or less; here large fish, the backs of which could be seen readily, were caught with dip nets. Some small fish probably have escaped each census by staying in this blind channel. Poisoning of this channel was considered impractical because fish held in the spillway basin had to be returned to the refilled diversion ditch in the lake basin after only a small volume of water had collected behind the gate of the outlet valve.
An attempt in $19+9$ to poison Dry Run Creck within the lake basin was a failure, presumably because of the low water temperature. it is probable that none of the toxicant entered the blind channel near the dam, as the outlet valve was not kept closed long enough for water to back up into this channel from the diversion ditch.

On each census after the lake was drained and all fish were collected (that could be collected), the outlet valve was closed and water was allowed to collect in the diversion ditch above this valve. When this ditch was bank-full of clear water for 150 or more yards above the valve (usually about 12 hours after the valve was closed), the amount of water

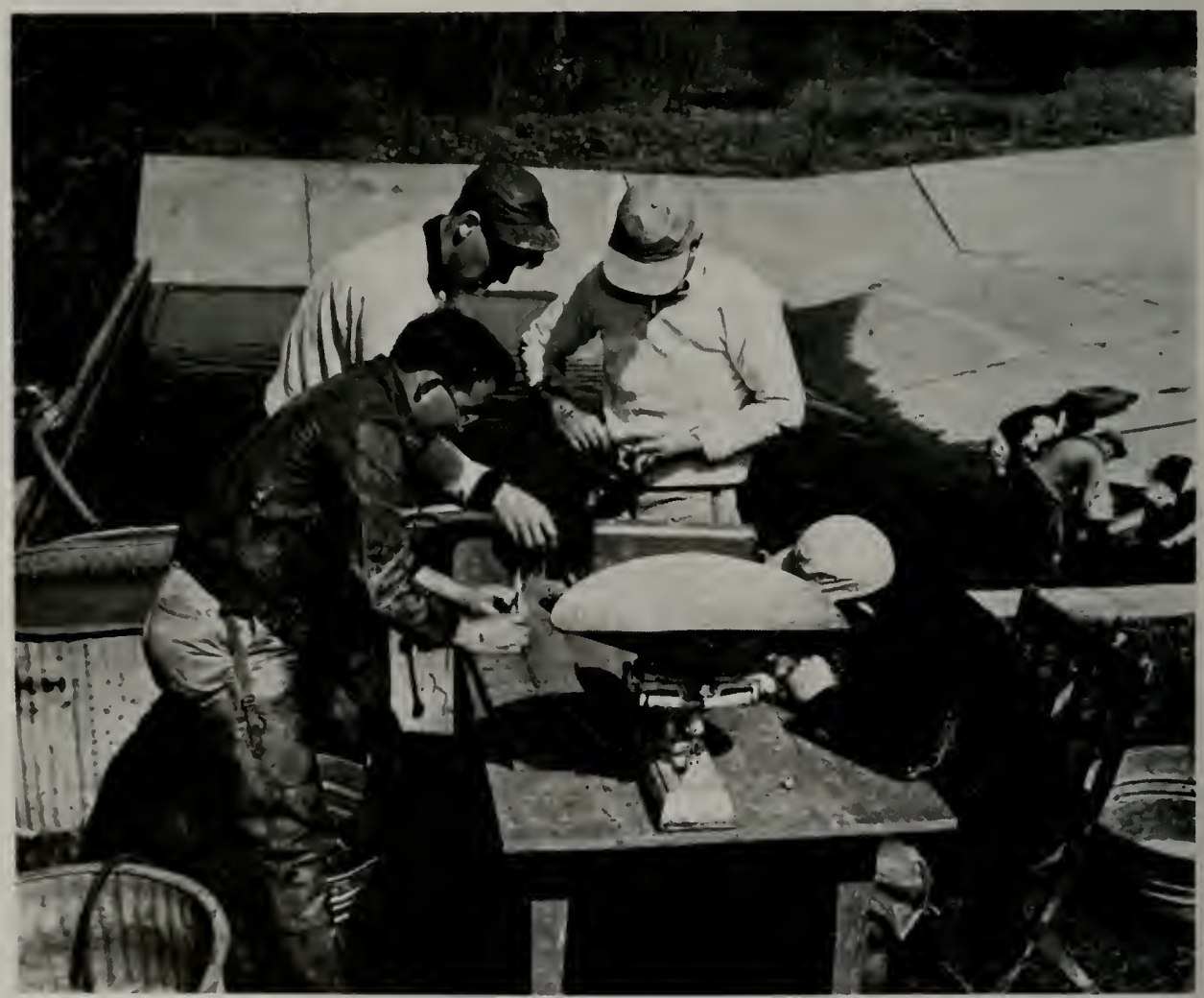

Fig. 10.- Handling fish at Ridge Lake. When Ridge Lake was ready for restocking after a draining operation, selected fish to be returned to the water were handled in lots of 50 to 100 . The fish, held in the stilling basin at the lower end of the concrete surface spillway, were captured and placed in a stock tank (left of center). From this they were removed individually and weighed, measured, "scaled" (had a few scales removed for later age determination), marked (fin-clipped), or had previous marks recorded, and placed in a second stock tank (lower left). When the second tank became crowded, the fish were transferred quickly to covered subs on a horse-drawn sled, hauled over the dam, and replaced in the lake. 


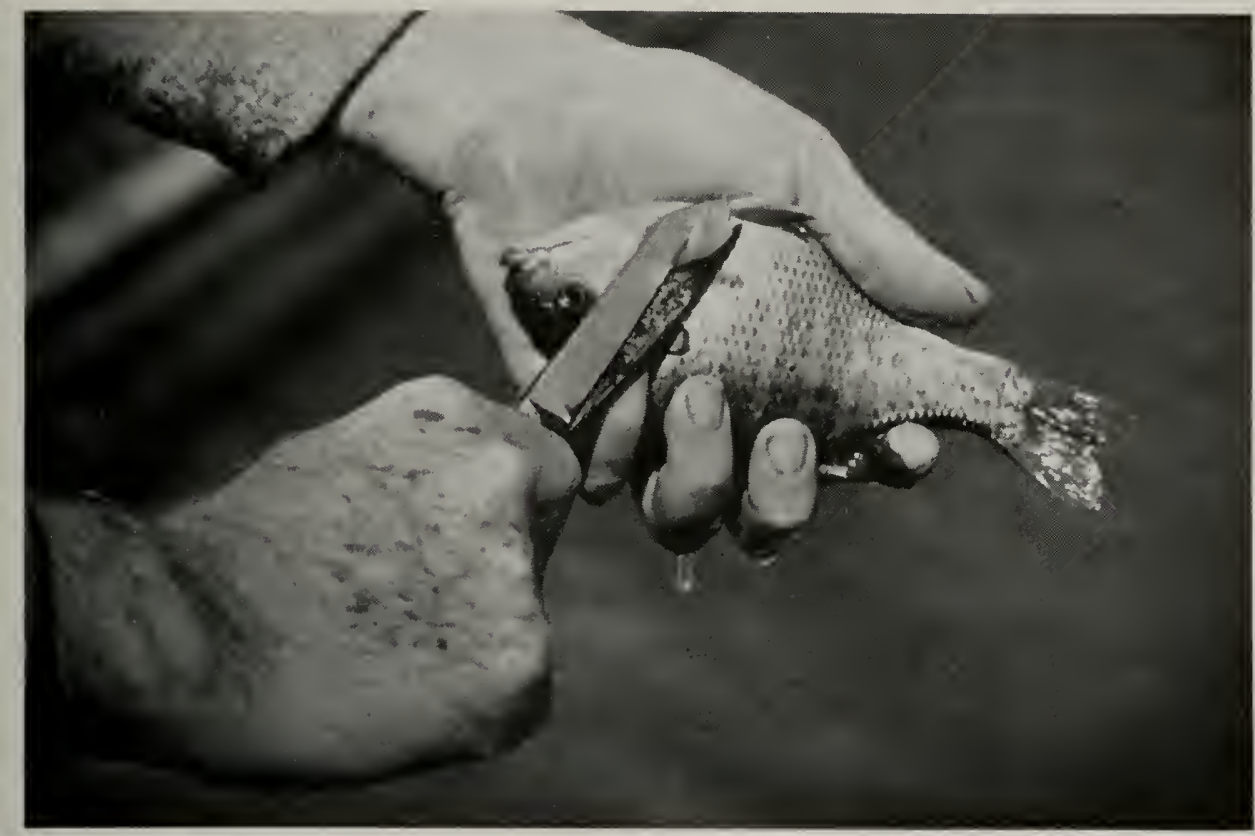

Fig. 11.-Marking bluegill at Ridge Lake. Each new fish (unmarked) returned to the lake after a draining census was marked by the removal of one fin. Most bluegills live only about + to 5 years, and few of them appeared in more than one of the spring censuses after being marked. Many bass appeared in several censuses, because their normal life span in Ridge Lake is 8 to 10 years.

was considered sufficient to begin restocking the lake with the fish held in the stilling basin at the base of the surface spillway. As the fish selected for the restocking had not been previously processed, a work station was set up on the edge of the spillway stilling basin with two large stock-watering tanks filled with clean water and supplied with aerating pumps, fig. 10. A table, measuring boards, and weighing scales were set up nearby. The fish were moved, 50 to 100 at a time, from the stilling or holding basin to one of the stock tanks; from this they were removed individually and weighed, measured, "scaled" ( 8 to 10 scales removed from side of fish below the dorsal fin), fin-clipped (or had previous finclip recorded), and placed in the second stock tank. When this second tank became crowded, the fish in it were transferred quickly to covered tubs on a horsedrawn sled, hauled over the dam, and replaced in the lake. No fish that appeared sluggish or emaciated, or that showed evidence of injury from its passage through the outlet valve and tunnel, was used in the restocking. On no census was there any evidence of undue mortality among the fish that were returned to the lake. Operational mortality was believed to have been rather low, because a large percentage of the marked bass returned to the lake after each census were either caught by fishermen or recaptured in subsequent censuses.

In the 19+3, 19+5, and $19+7$ censuses, when 1 -inch-mesh poultry netting was used for the temporary fish screen, many small fish passed through this screen with the water. An estimate was made of the number of these fish in $19+5$ and $19+7$, but not in 1943, when, because a dominant brood of 5 - to 8 -inch bass was present, the number was probably lowest.

When the permanent concrete frame for fish screens was built below the dam in 1948 , the removable screens to fit this frame were covered with quarter-inchmesh hardware cloth. 'This small mesh was no more satisfactory for gaining an accurate count of the small fishes than was 
the 1-inch mesh, as thousands of small bluegills became gilled in the screen mesh. The fish impeded the How of water through the screen and stopped draining operations until they could be removed. It became an inpossible task to make any count of these young. For the 1951 census the screen frames were covered with 1-inch-mesh hardware cloth, and no attempt was made to estimate the numhers of small bluegills less than 2 inches all in Illinois. 'Table 2 lists the lakes from which these bass were taken, the numbers, weights, and length ranges of the bass, and the dates of their introduction into Ridge Lake.

Before being released, all the hass were fin-clipped for later identification. From each Craborchard Lake bass, the left pectoral fin was clipped, from each Lake Chautauqua bass, the right pectoral, and from each Lake Glendale bass, the dorsal.

Table 2.-Source, number, weight, and length range of largemouth bass used in stocking Ridge lake.

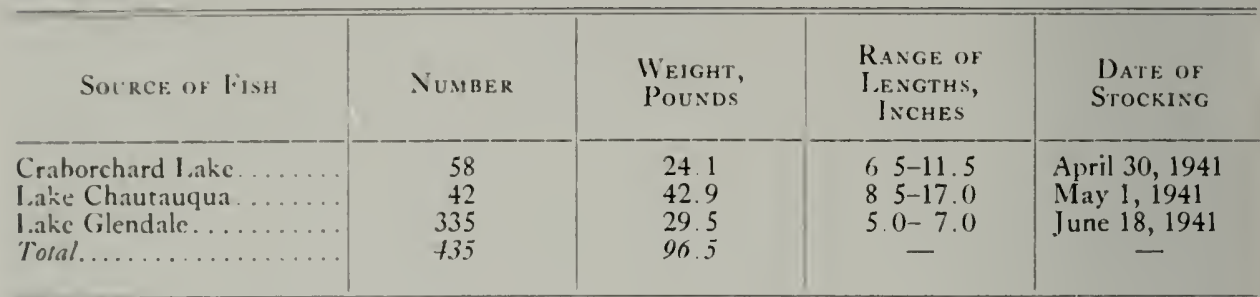

long that went through; however, toward the end of the draining operation a fine-mesh dip net, held in the flow below the screen for 1 minute, caught 381 small bluegills weighing 2.75 pounds.

As mentioned previously, fish were finclipped prior to their being returned to the lake following a census, fig. 11 . 'The fin clipped in the $19+3$ census was the left pectoral; in the $19+5$ census the right pectoral; in the $19+7$ census the left pelvic; in the 1949 census the dorsal; and in the 1951 census the left pectoral. In each census, only the fish that had not been fin-clipped previously were marked. 'Thus, all fish more than 22 months old (except the few that as small fish had escaped capture by staring in the lake basin) bore marks that assigned them to specific 2-year periods; for example, a 3.5-pound bass caught in 1949 showed the left pectoral fin missing, which indicated that it had been spawned in 1941 or $19+2$ and marked when heing returned to the lake after the $19+3$ census.

\section{Population Dynamics}

The +35 largemouth bass with which Ridge Lake was stocked in $19+1$ were wild fish netted from Craborchard Lake near Carbondale, Lake Chautauqua near Havana, and Lake Glendale near Robbs,
No largemouth bass from uutside sources have been placed in Ridge Lake since the original +35 were introduced in 19+1. Evidence presented later (pages 265 and 266) indicates that many of these original bass were sufficiently injured during netting operations or in transportation to Ridge Lake to cause them to die within a short time after their introduction into the lake, particularly the Lake Glendale fish that were caught and moved in June.

Bluegills were first placed in Ridge Lake on June 27, 194t, when 107 of these fish, 7.5 to 7.5 inches in length, were brought in from Lake Chautauqua. Of these, 7 were dead or dying on arrival, but 100 were released. Later in the same year, on July 13, 29 bluegills between 5 and 6.5 inches in length were brought to the lake from a strip-mine pond near Danville, Illinois. No weights were taken of either group of hluegills. From each Lake Chautauqua fish was clipped the left pectoral fin and from each Danville fish the right pectoral. No other stocks of bluegills have been introduced since these 129 were released in 1944 .

In April, May, and June of 1949. three groups of warmouths, Chaenobryttus coronarius (Bartrain), totaling 138 fish were placed in Ridge Lake to test the ability of these fish to expand their popu- 
November, 195+ Bennett: Largenouth Bass 1n Ridge Lake

Table 3.-Largemouth bass, bluegills, and other fish that were permanently removed from Ridge Lake by angling and in draining operations during the 1941-1951 study period. Not included in figures for the draining censuses were fish, less than a year old, so small that accurate counts were not possible.

\begin{tabular}{|c|c|c|c|c|c|c|c|c|c|c|c|c|}
\hline \multirow{3}{*}{ YEA } & \multicolumn{6}{|c|}{ Permanently Removed by Angling } & \multicolumn{6}{|c|}{ Permanentli Removed in Draining Censuses } \\
\hline & \multicolumn{2}{|c|}{$\begin{array}{c}\text { LARGEMOUTH } \\
\text { BASS }\end{array}$} & \multicolumn{2}{|c|}{ Bluegrllas } & \multicolumn{2}{|c|}{$\begin{array}{c}\text { OTHER } \\
\text { Fish }\end{array}$} & \multicolumn{2}{|c|}{$\begin{array}{c}\text { LARGEMOUTH } \\
\text { BASS }\end{array}$} & \multicolumn{2}{|c|}{ BLUEGILLS } & \multicolumn{2}{|c|}{$\begin{array}{c}\text { OTHER } \\
\text { FISH }\end{array}$} \\
\hline & $\frac{\grave{\Xi}}{\Xi}$ & 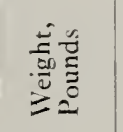 & $\frac{\grave{\Xi}}{\stackrel{\Xi}{\Xi}}$ & 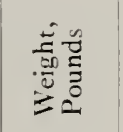 & $\frac{\grave{\Xi}}{\Xi}$ & 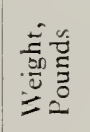 & 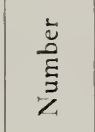 & 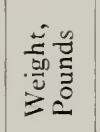 & 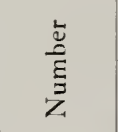 & $\begin{array}{l}\frac{1}{ \pm} \frac{0}{0} \\
\frac{50}{2} \\
=0\end{array}$ & $\frac{\frac{1}{\Xi}}{\frac{0}{3}}$ & 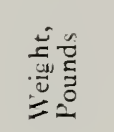 \\
\hline & J & 8.2 & - & - & - & - & - & - & - & & & - \\
\hline & 485 & 271. & - & - & - & - & - & - & - & - & - & - \\
\hline & 32 & 17. & - & - & - & - & 2,783 & 482.60 & - & - & 36 & 9. \\
\hline & 466 & 270.46 & - & - & 32 & 37.03 & - & - & - & - & - & - \\
\hline & 409 & 356.87 & 2 & 1.22 & 7 & 5. 15 & $994^{1}$ & 197.01 & $10,000^{2}$ & $10000^{2}$ & 762 & 463.21 \\
\hline & 362 & 263.35 & 1,686 & 228.03 & 284 & 45.97 & - & - & - & - & 一 & - \\
\hline & 181 & 195 & 644 & 111.61 & 38 & 5.65 & 2,117 & 79.62 & 64,868 & $3,194.97$ & 663 & 566.22 \\
\hline & 648 & 460 & 5,831 & 826.03 & 241 & 103.95 & - & - & - & - & - & - \\
\hline & 594 & 540.51 & 15 & 2. 92 & 6 & 2.82 & 1,012 & 102.97 & 19,714 & $1,564.31$ & 110 & 52.11 \\
\hline & 515 & 330.28 & 895 & 120.31 & 276 & 85.38 & - & - & & - & - & - \\
\hline 195 & $\overline{-}$ & - & - & - & - & - & 707 & 136.34 & 51,307 & $1,761.90$ & 1,079 & 154.12 \\
\hline 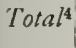 &, $7+3$ & $2,715.02$ & 9,073 & $1,290.12$ & 884 & 285.95 & 7,613 & 998.54 & $17.5,889$ & $6,621.18$ & 2,650 & $2+17.76$ \\
\hline
\end{tabular}

1 Figure includes an estimated 500 very small fish.

Figure estimated.

3 This report does not include the angling season of 1951.

* Total largemouth bass, 11,356 weighing 3,713.56 pounds; total bluegills, 154,962 weighing 7,911.30 pounds; total other fish, 3,534 weighing 1,530.71 pounds; grand total of fish, 169,852 weighing 13,155.57 pounds.

lation when introduced into water inhabited by a dominant bass population and a reduced population of bluegills. The warmouths varied in length between 3 and 9 inches and were fin-clipped for later identification.

Neither largemouth bass, bluegills, nor warmouths are indigenous to Dry Run Creek. An application of fish poison to the part of the creek within the lake basin, prior to the impoundment of the water, resulted in a kill of the following species:* stoneroller, Campostoma anomalum (Rafinesque); creek chub, Semotilus atromaculatus (Mitchill); creek chubsucker, Erimyzon oblongus (Mitchill); silverjaw minnow, Ericymba buccata Cope; green sunfish, Lepomis cyanellus Rafinesque; longear sunfish, Lepomis megalotis (Rafinesque); bluntnose minnow, Hyborhynchus notatus (Rafinesque); white sucker, Catostomus commersonnii (Lacépède); yellow bullhead, Ameiurus natalis (Le Sueur); and black bullhead, Ameiurus melas (Rafinesque).

* Names from American Fisheries Society (1948), except the scientific name for the black buffalo and the common the scientific name for the black buffalo and the common
and scientific names for the silverjaw minnow, al! of which are from Hubbs \& Lagler (1947).
None of these appeared in the lake in numbers during the 1941-1951 study period except the green sunfish, the black bullhead, and the yellow bullhead. Carp, Cyprinus carpio Linnaeus, and one black buffalo, Ictiobus niger (Rafinesque), appeared in the $19+7$ draining census. A few carp appeared in the 1951 census. These fish are believed to have moved up Dry Run Creek from the Embarrass River and to have entered the lake by swimming up over the surface spillway during periods of high water.

Each time the lake was drained, fish of the species indigenous to Dry Run Creek (largely green sunfish and black bullheads) were removed, but within the next 2 years following each draining a few more of these species had worked down into the lake from the stream above and had produced small numbers of young. Although green sunfish never became a substantial part of the population, usually some were present. Black bullheads were particularly numerous during the 19431946 period and many taken by fishermen were more than a pound in weight.

The numbers and weights of fishes per- 


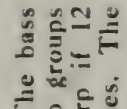

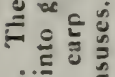
赵弱可

כ约

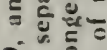

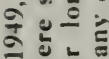

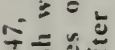

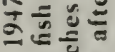

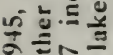

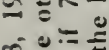

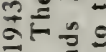
s.

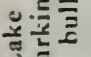
(a)

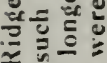
$\div \div \div \overline{0}$

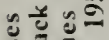

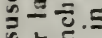

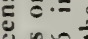
x.: =

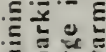
要道: 돌

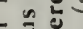

5.

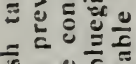

흔

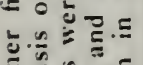

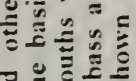

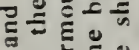
(5)

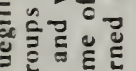

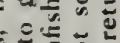

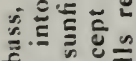
可的

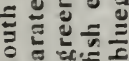
政

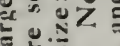

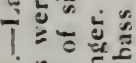
$+\%$

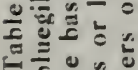

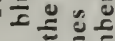

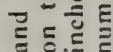

\begin{tabular}{|c|c|c|c|c|c|c|c|c|c|c|c|c|c|c|}
\hline$\hat{\tilde{z}}$ & 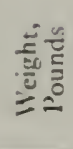 & 1 & $\begin{array}{l}\tilde{b} \\
\Omega\end{array}$ & $\begin{array}{l}8 \\
a\end{array}$ & $\begin{array}{l}\frac{1}{\ddagger} \\
\ddagger\end{array}$ & $\begin{array}{l}\infty \\
0 \\
\text { तj }\end{array}$ & $\begin{array}{l}8 \\
\stackrel{3}{+}\end{array}$ & 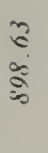 & 1 & I & & & 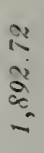 & 1 \\
\hline & 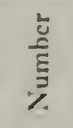 & 1 & + & $N$ & $=$ & $\cong$ & ल & $\stackrel{2}{=}$ & 1 & 1 & స్ర్రె & & $\begin{array}{l}\hat{g} \\
\text { in }\end{array}$ & I \\
\hline ज़ & 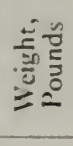 & $\stackrel{\Xi}{i}$ & $\begin{array}{l}= \\
\bar{a}\end{array}$ & 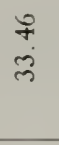 & $\begin{array}{l}\vec{t} \\
\overrightarrow{\vec{U}}\end{array}$ & $\begin{array}{l}+ \\
+ \\
+ \\
\text { in }\end{array}$ & 1 & $\begin{array}{l}\hat{b} \\
\hat{a}\end{array}$ & 1 & 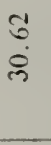 & $\begin{array}{l}\hat{s} \\
\dot{n} \\
\hat{n} \\
\text { ñ } \\
-\end{array}$ & 1 & $\begin{array}{l}\bar{m} \\
\vec{c} \\
c \\
=\end{array}$ & 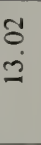 \\
\hline I & 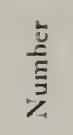 & - & $\hat{\imath}$ & $a$ & $\Sigma$ & के & । & $\begin{array}{l}\text { के } \\
\text { oi }\end{array}$ & 1 & $\&$ & $\begin{array}{l}\text { तु } \\
\text { פ }\end{array}$ & 1 & $\begin{array}{l} \pm \\
\text { I } \\
2\end{array}$ & $\stackrel{\infty}{i n}$ \\
\hline 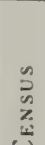 & 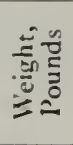 & $\begin{array}{l}n \\
\mathfrak{b}\end{array}$ & $\begin{array}{l}\stackrel{n}{n} \\
\stackrel{n}{n}\end{array}$ & $\begin{array}{l}\tilde{\rho} \\
\infty \\
+\end{array}$ & $\begin{array}{l}\Delta \\
\text { a } \\
\text { ñ } \\
\text { m }\end{array}$ & 1 & 1 & $\begin{array}{l}\hat{A} \\
\stackrel{0}{\circ}\end{array}$ & $\begin{array}{l}\approx \\
\infty \\
0\end{array}$ & 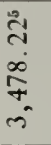 & 1 & 1 & 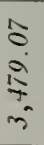 & 1 \\
\hline a & 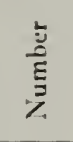 & - & 3 & $\stackrel{\sim}{ }$ & $\begin{array}{l}\tilde{y} \\
\underset{i}{i}\end{array}$ & 1 & I & $\begin{array}{l}\text { 今े } \\
\text { oi }\end{array}$ & N & 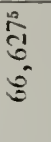 & 1 & 1 & $\begin{array}{l}\text { बे } \\
\text { है } \\
8^{-}\end{array}$ & I \\
\hline $\begin{array}{l}a \\
\vec{b} \\
\vec{n}\end{array}$ & 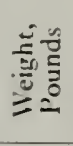 & $\begin{array}{l}3 \\
\text { ले }\end{array}$ & $\begin{array}{l}\text { त్ } \\
\text { o }\end{array}$ & 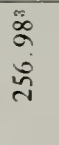 & 1 & 1 & 1 & $\begin{array}{l}\bar{\alpha} \\
\bar{\alpha} \\
\hat{\alpha}\end{array}$ & $\begin{array}{l}\stackrel{+}{i} \\
\stackrel{i}{i}\end{array}$ & $\begin{array}{l}\overline{8} \\
\dot{g}\end{array}$ & I & 1 & $\begin{array}{l}\text { रे } \\
\text { â }\end{array}$ & $\begin{array}{l} \pm \\
\dot{m} \\
\dot{m}\end{array}$ \\
\hline$\stackrel{2}{a}$ & 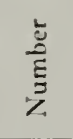 & 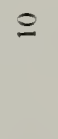 & $\stackrel{9}{\mathrm{f}}$ & 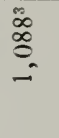 & 1 & 1 & 1 & $\begin{array}{l}\bar{l} \\
\overrightarrow{0}\end{array}$ & 5 & $\begin{array}{l}\bar{\delta} \\
\varnothing \\
\varrho\end{array}$ & 1 & 1 & $\begin{array}{l}\tilde{s} \\
\stackrel{8}{q}\end{array}$ & త్ \\
\hline & 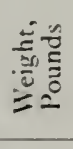 & $\begin{array}{l}\subseteq \\
\text { in }\end{array}$ & $\begin{array}{l}\vec{D} \\
\stackrel{i}{d} \\
\stackrel{\infty}{\infty}\end{array}$ & 1 & 1 & 1 & 1 & 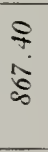 & 1 & 1 & 1 & 1 & 1 & $\begin{array}{l}\text { on } \\
\stackrel{0}{0} \\
0\end{array}$ \\
\hline ? & 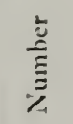 & $=$ & $\begin{array}{l}\text { 鼠 } \\
=\end{array}$ & 1 & I & 1 & 1 & $\begin{array}{l}\mathbb{N} \\
\approx\end{array}$ & 1 & 1 & $!$ & 1 & 1 & in \\
\hline
\end{tabular}

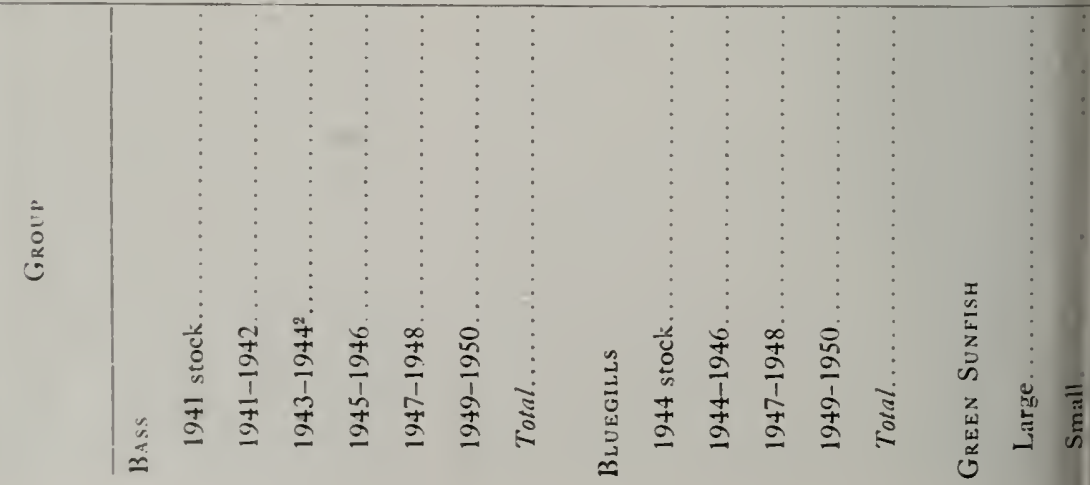


November, 1954 Bennett: Largenouth Bass in Ridge Lake

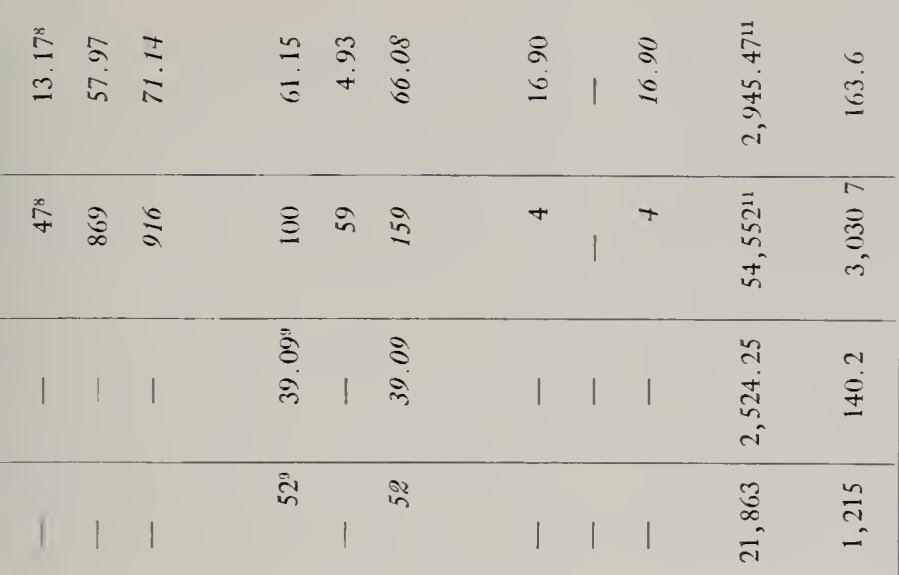

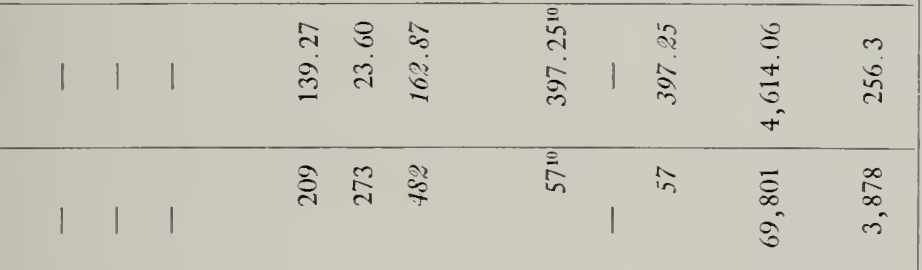

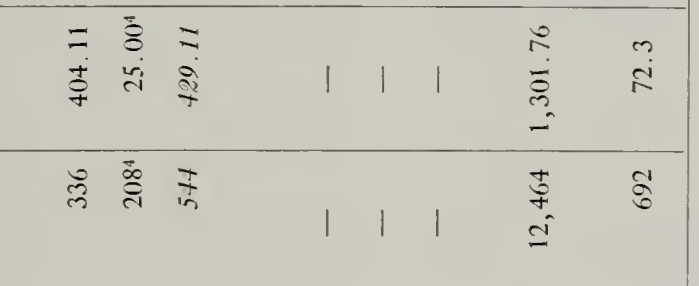

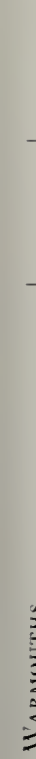

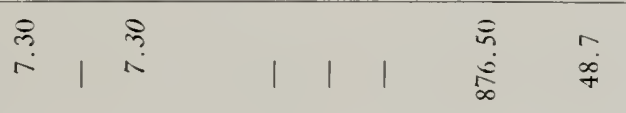

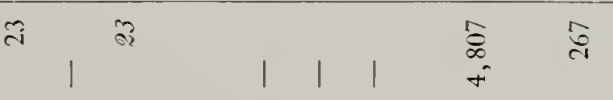

\begin{tabular}{l}
\hline \\
\hline \\
\hline \\
\hline \\
\hline
\end{tabular} 
manently removed from the lake during the $19+1-1950$ period by angling (vield) and of those permanently removed in the 19+3-1951 draining censuses (culling operations) are shown in table 3 . Not included in figures for the draining censuses were fish, less than a year old, so small that accurate counts of them were not possible. $\ln 19+1$ and $19+3$, the lake was not opened to the public, and the angling records for both years are those of Natural History Survey personnel who were taking samples of fish for growth studies. Many additional bass were taken by Surves personnel and released alive in $19+1$ and 19+3; those listed in table 3 were fish so severely hooked as to make their survival uncertain.

The fact that, from original stocks of only +35 bass and 129 bluegills, more than 11,300 bass and more than 154,000 bluegills were removed from Ridge Lake during a 10-year period of operation is good evidence that both species are capable of expanding their populations to approach the carrying capacity of waters into which they are introduced and of maintaining these populations indefinitely under a system of operation such as has been followed at Ridge Lake. In this experiment, the bluegills showed a highes reproduction rate than did the bass. Other species, primarily black bullheads and green sunfish, were able to survive and in some years to increase their numbers under the predation pressure of a strong bass population.

Whereas table 3 lists the numbers and weights of fishes permanently removed from the lake by angling and in the draining censuses, table + lists the numbers and weights of fishes taken in these draining censuses and table 5 lists the numbers and weights of fishes returned to the lake following the censuses. Both tables $t$ and 5 are arranged to show data on the individual fin-clip groups of largemouth bass and bluegills for each of the five censuses in which they were involved. Green sunfish, bullheads, and other indigenous fishes, removed from the lake on each census, and also introduced warmouths, have been separated in the census tabulations, table 4 , into "large" and "small" categories. Any green sunfish or warmouth of 6 inches or more in lengtl

Table 5.-Largemouth bass and bluegills returned to Ridge Lake following each of five draining censuses. Fish were separated into groups on the basis of previous fin markings or lack of such markings.

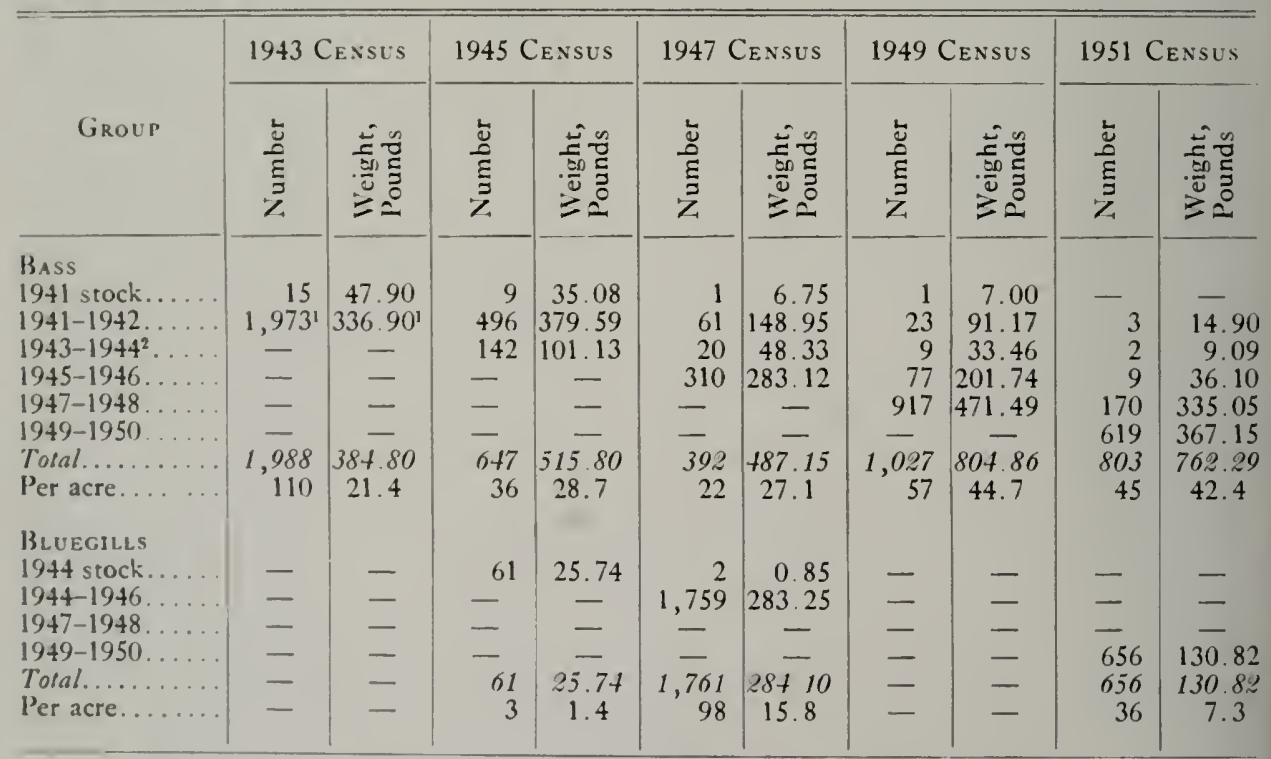

1 Figure includes estimated 473 bass weighing estimated 80.41 pounds that escaped the 1943 census.

2 Some of the fish of this group were spawned in 1941 or 1942 , escaped the 1943 draining census, and appeared as unmarked fish in the census of 1945 , when they were given the same mark as the fish spawned in 1943 and 1944 . 
was considered "large," and any bullhead of 7 inches or more in length was placed in the same category. The 57 carp taken in $19+7$ averaged almost 7 pounds each and those in 1951 about + pounds each; no "small" carp (less than 12 inches in length) were taken.

Comparison of tables $3,+$, and 5 will show that following each draining census many bass and bluegills were not returned to the lake. Only in the year $19+3$ were bass smaller than $\delta$ inches total length returned to the lake. Most of the tish making up the early $19+3$ population of small bass (bass other than the $19+1$ original stock) were 6 to 9 inches in length. In the $19+3$ census operation, the population of small bass was reduced by about 58 per cent $(4,75+$ reduced to 1,973 , according to tables $t$ and 5). Only 1,500 of the,+ 281 bass actually taken in the $19+3$ census were returned to the lake as marked fish. However, other small bass were later found to be in the lake. During the summer of $19+3$ when Ridge Lake was not opened to the public, Natural History Survey personnel took, and released, 363 bass of the size range of the $19+1$ and $19+2$ broods; 276 of these were fish that had been marked and 87 were unmarked fish. On the basis of the relationship between unmarked fish and marked fish in the catch it was calculated that, in the lake, there were about +73 of these small bass that had escaped capture, possibly by remaining, at the time of the census, in the blind stream channel between the mouth of the diversion ditch and the dam. This number and their interpolated weight were added to the census tabulation, table $t$, and to the tabulation of small bass actually replaced in the lake following the census, table 5 .

In the 1949 census, there was a large number of unmarked bass ranging between 9 and 10 inches in length. These fish could be expected to grow to 10 inches or larger during the 1949 fishing season and, as fishermen were asked to bring in all bass caught, regardless of size, it was assumed that these fish might add to the $19+9$ vield, eren though they failed to reach the 10 -inch legal length. For these reasons, bass of 9 inches or larger were returned to the lake following the $19+9$ census. In the 1951 census,
277 unmarked bass 8 to 10 inches long were marked and returned to the lake, along with $3+2$ unmarked bass of 10 inches or longer, table 5 .

At the time of the $19+5$ draining census, only 61 of the 129 bluegills with which Ridge Lake was stocked in $19+4$ were recovered, table 4 . These had produced a large number of young in 194t, ranging in size from 1.5 to 2.5 inches by March of $19+5$. A rough estimate of the number that came through the screen below the outlet was 10,000 , weighing 100 pounds. Others probably remained within the lake basin, although the blind stream channel near the dam had filled in considerably since the $19+3$ draining.

The 61 bluegills remaining from the $19+4$ stock were returned to the lake following the $19+5$ census. In the 1947 census 2 years later, the bluegill population was found to consist of 2 of these 61 fish; 6,873 other bluegills of 6 or more inches in length, weighing $1,10+.53$ pounds; $49,75+$ bluegills of 3 to about 6 inches in length, weighing 2,223.69 pounds; and approximately 10,000 bluegills of 1.5 to about 3 inches in length, weighing approximately 150 pounds. These groups made a total of 66,629 fish, weighing $3,479.07$ pounds, table 4 .

Following the draining operation in $19+7,1,759$ of the larger unmarked bluegills were fin-clipped (left pelvic fin) and returned to the lake along with the 2 fish from the original stock of 1944, making a total of 1,761 fish weighing $28+.1$ pounds, table 5 . When the fish population was censused again in 1949, only 90 of these marked bluegills were retaken and the entire bluegill population, exclusive of an unestimated number of fish about 1 inch in length, numbered only $19,71+$ fish, weighing $1.56+.31$ pounds, table $t$. This poundage was less than half of that collected in the $19+7$ census.

An attempt was made in the 1949 draining census to remove all bluegills from the lake. Although $19,71+$ of these fish were removed, table $t$, and none returned, and the stream channel and diversion ditch were treated with a heavy dosage of cubé ( 5 per cent rotenone) to poison the escaped fish, the attempt was unsuccessful. In March, 1951, when the fish population was again censused, nearly 
52.000 bluegills were found to be present, showing that many small fish had escaped the treatment. Small bluegills that survived the 1949 draining and poisoning operations must have been subjected to heavy predation from bass, because in that year the large bass population that had developed in the 19+7-1948 period was concentrated in 11 acres of water having much less than one-half of the volume of the full lake. At the time of the draining, these small bluegills may have lived in eddies of the flowing creek, or in shallow pools on the lake bottom where water was trapped by uneven deposition of silt, until the rising water behind the dam flooded their hiding places and released them to the open water. Scales collected from a number of the larger bluegills taken in the 1951 census indicated that these fish must have been survivors of the 1949 census. Since 663 large bluegills appeared in the 1951 census, table 4 , it seems quite probable that the number that escaped the 1949 census may have numbered several thousand, most of which were eaten by bass. As it was quite obviously impossible to rid the lake of bluegills without allowing the basin to dry out thoroughly, it was decided to return 656 of the larger bluegills to the water following the 1951 census, table 5 .

Table 6.-Numbers and poundages of largemouth bass, bluegills, green sunfish, and hlack bullheads taken by fishermen from Ridge Lake, 1941-1950. In addition to the fish included in this table were 5 large warmouths, weighing 1.98 pounds, caught in 1949 , and 50 small warmouths, weighing 3.12 pounds, and 3 large warmouths, weighing 1.07 pounds, caught in 1950.

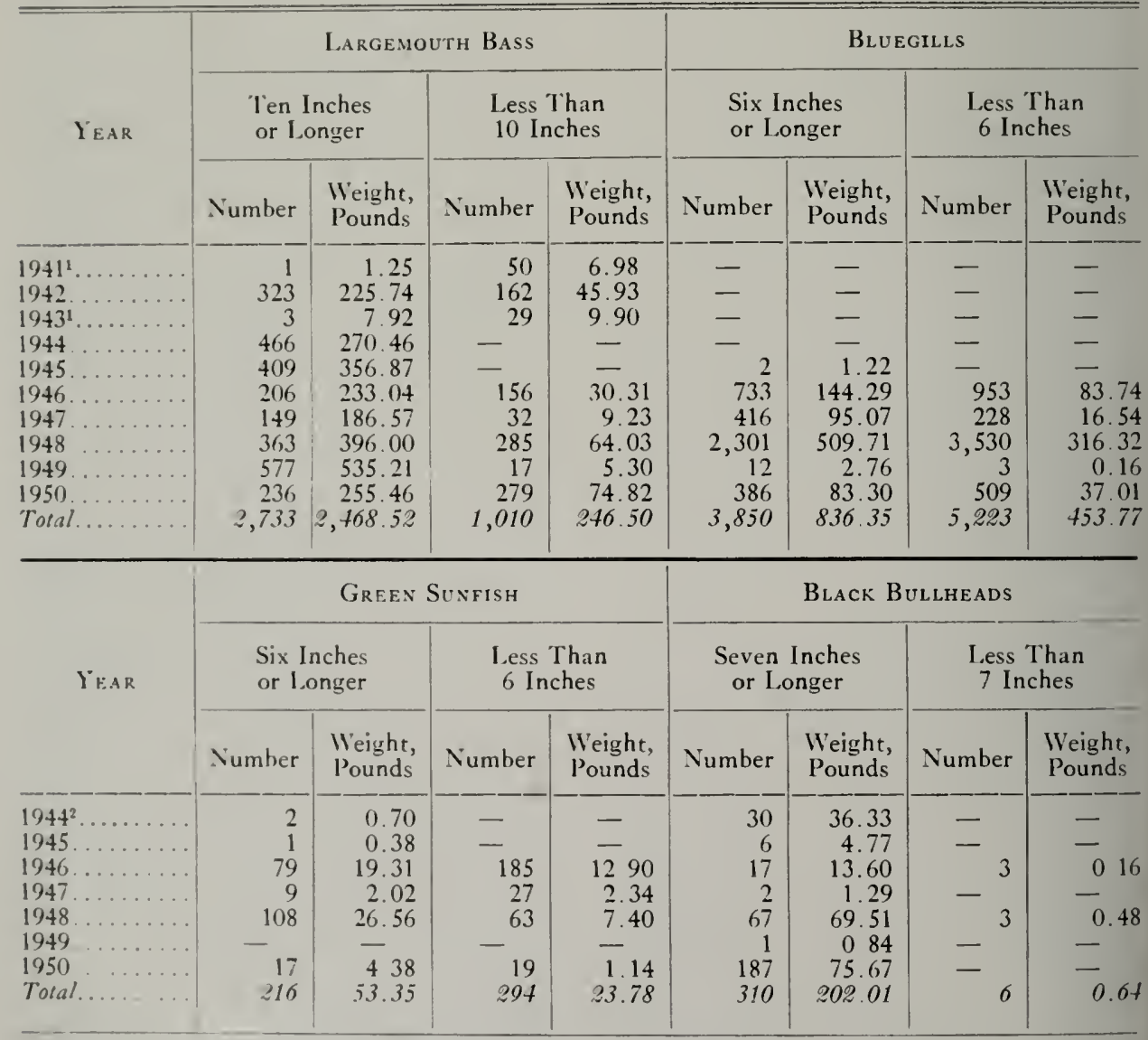

Lake not open to public fishing in this year.

2 No green sunfish or black bultheads were caughe in years prior to 1944. 
The tabulation of fishes removed by angling, table 3 , includes all of the fish taken on hook and line, regardless of whether they were large enough to interest anglers. In table 6, the information on yield has been expanded to show the relative numbers and weights of fishes of desirable and undesirable sizes. During the period between the opening of Ridge Lake and June 30, 1951, the minimum legal length for largemouth bass in Illinois was 10 inches. In $19+6$ and subsequent years, fishermen at Ridge Lake were requested to bring in all fish they caught, regardless of size. In table 6, bass are separated into those of 10 inches or more in length and those of less than 10 inches.

Minimum lengths for desirable sizes of fishes of other species caught at Ridge Lake have been set arbitrarily at 6 inches for bluegills, green sunfish, and warmouths, and 7 inches for bullheads. Table 6 shows that among the largemouth bass and bullheads taken by anglers the numbers of fishes of desirable sizes far outnumbered those of undesirable sizes. Among the bluegills and green sunfish, however, the smaller fishes taken by anglers outnumbered the fishes of desirable sizes.

The poundages of fish per acre of water are shown in table 7 for the draining censuses and for the fish returned to the lake after censusing, and in table 8 for the annual catches by fishermen. Of particular interest in table 7 is the gradual reduction in poundage of bass supported by the lake from March, 1943, to March, 1947, and the rapid recovery that took place between March, 1947, and March, 1949. This reduction and recovery in poundage of bass appears to bear no relationship to the annual catch of bass made by anglers, table 8 (although combined bass yields of 1945 and $19+6$ were higher than the combined yields of $19+3$ and 1944); the bass yield in 1948 (25.6 pounds per acre) was considerably higher than that in anv prior year and yet, after this high yield of 1948, the draining census of 1949 , table 7 , showed a bass population that exceeded that found in anv other census.

The actual gain in poundage of largemouth bass during each of the four 2- year periods may be determined by subtracting the poundage of the original stock or the poundage of the bass replaced in the lake after any given draining census from the poundage taken on the next census following, table 7 , and to this figure adding the poundage of fish taken by anglers during the fishing seasons between these two censuses, table 8 .

Figured on this basis, the bass gain in the 1941-19+3 period was 58.5 pounds per acre; in the $19+3-1945$ period, 34.2 pounds per acre; in the 1945-19+7 period, 37.2 pounds per acre; in the 19+7-1949 period, 59.8 pounds per acre; and in the 19+9-1951 period, 53.5 pounds per acre. Thus, although the bass population reached a low point in the $19+7$ census, the actual gain of the $1945-19+7$ period was greater than that of the 19+3-1945 period.

The bass gains of the $19+1-1943$ period, the 1947-1949 period, and the 1949-1951 period exceeded those of the other two periods, and it seems probable that with these gains the bass population approached the maximum poundage that the lake would support (approximately 50 pounds per acre).

Figured on the same basis as that used for bass, tables 7 and 8 , the gain in bluegills was 204.7 pounds per acre in the 19+5-1947 period, 123.2 pounds in the 19+7-1949 period, and 112.1 pounds in the 1949-1951 period. It is difficult to estimate the maximum poundage of bluegills the lake will support, but, figured on the basis of the 1947 census, it might exceed 200 pounds per acre.

As may be seen in table 7, the total poundages of fish supported by Ridge Lake at the times of the various censuses varied widely. Because largemouth bass of the 1941 year-class made little or no growth in 19+2, it is assumed that at the time of the census in 1943 the largemouth population was approaching the carrying capacity of the lake for this species. Theoretically, when other species are present along with largemouth bass, the total poundage of fish that can be supported by the lake may be greatly increased; except in 1947, when the bluegill population may have been nearing the potential maximum for bluegills alone, the populations of fishes other than bass prob- 
Table 7.-Pounds of fish, per acre of lake, taken in draining censuses of Ridge Lake and pounds, per acre of lake, returned following each census, 1943-1951. The area of the lake was assumed to be 18 acres.

\begin{tabular}{|c|c|c|c|c|c|c|c|}
\hline \multirow{2}{*}{ YEAR } & \multicolumn{4}{|c|}{ Taken in Draining Census } & \multicolumn{3}{|c|}{$\begin{array}{c}\text { Returned liollowing } \\
\text { the. Census }\end{array}$} \\
\hline & $\begin{array}{l}\text { Large- } \\
\text { mouth } \\
\text { Bass }\end{array}$ & Bluegills & $\begin{array}{l}\text { Other } \\
\text { liish }\end{array}$ & $\begin{array}{l}\text { Total in } \\
\text { Census }\end{array}$ & $\begin{array}{l}\text { Large- } \\
\text { mouth } \\
\text { Bass }\end{array}$ & Bluegills & $\begin{array}{l}\text { War- } \\
\text { mouths }\end{array}$ \\
\hline $\begin{array}{c}1941 \text { (original } \\
\text { stock) . . . } \\
1943 \ldots \ldots \ldots \\
1945 \ldots \ldots \ldots \\
1947 \ldots \ldots \ldots \\
1949 \ldots \ldots \ldots \\
1951 \ldots \ldots \ldots\end{array}$ & $\begin{array}{l}-\overline{48.2} \\
39.6 \\
31.5 \\
50.4 \\
49.9\end{array}$ & $\begin{array}{r}- \\
\overline{7} .0 \\
193.3 \\
86.9 \\
105.2\end{array}$ & $\begin{array}{r}\overline{0.5^{1}} \\
25.7^{1} \\
31.5^{2} \\
2.9^{3} \\
8.7^{4}\end{array}$ & $\begin{array}{r}\overline{48.7} \\
72.3 \\
256.3 \\
140.2 \\
163.8\end{array}$ & $\begin{array}{r}5.3 \\
21.4 \\
28.7 \\
27.1 \\
44.7 \\
42.4\end{array}$ & $\begin{array}{l}- \\
\overline{1.4} \\
15.8 \\
\overline{7.3}\end{array}$ & $\begin{array}{l}- \\
\overline{-} \\
\overline{-} \\
2.9\end{array}$ \\
\hline
\end{tabular}

1 Black bultheads and green sunfisl.

2 Black bullheads, green sunfish, carp, and one black buffalo.

3 Black bullheads, yellow bullheads, and green sunfish.

- Warmouth bass, black bullheads, carp, and miscellaneous minnows.

Table 8.-Pounds of fish per acre of lake (18 acres) taken by fishermen and fishing pressure at Ridge Lake, 1941-1950.

\begin{tabular}{|c|c|c|c|c|c|}
\hline \multirow{2}{*}{ YeAR } & \multicolumn{4}{|c|}{ Yield, Pounds per Acre } & \multirow{2}{*}{$\begin{array}{l}\text { Fishing Pressure, } \\
\text { Man-Hours per ACre }\end{array}$} \\
\hline & $\begin{array}{c}\text { 1.argemouth } \\
\text { Bass }\end{array}$ & Bluegills & $\begin{array}{l}\text { Green } \\
\text { Sunfish }\end{array}$ & $\begin{array}{c}\text { Black } \\
\text { Bullheads }\end{array}$ & \\
\hline $\begin{array}{l}1941^{1} \ldots \\
1942 \ldots \\
1943^{1} \ldots \\
1944 \ldots \\
1945 \ldots \\
1946 \ldots \\
1947 \ldots \\
1948 \ldots \\
1949 \ldots\end{array}$ & $\begin{array}{r}0.5 \\
15.1 \\
1.0 \\
150 \\
19.8 \\
14.6 \\
10.9 \\
25.6 \\
30.0 \\
18.3\end{array}$ & $\begin{array}{r}- \\
\overline{-} \\
\overline{-} \\
0.1 \\
12.7 \\
6.2 \\
45.9 \\
0.2 \\
6.7\end{array}$ & $\begin{array}{l}\overline{-} \\
\overline{-} \\
+^{2} \\
+^{2} \\
1.8 \\
0.2 \\
1.9 \\
\overline{0.5}\end{array}$ & $\begin{array}{l}-\overline{-} \\
\overline{-} \\
2.0 \\
0.3 \\
0.8 \\
0.1 \\
3.9 \\
+{ }^{2} \\
4.2\end{array}$ & $\begin{array}{r}\overline{212} \\
\overline{9} \\
105 \\
168 \\
155 \\
320 \\
220 \\
224\end{array}$ \\
\hline
\end{tabular}

1 Lake not open to public fishing in this year.

2 L.ess than 0.1 pound per acre.

${ }^{3}$ Consists of 0.3 pound per acre ol green sunfish and 0.2 pound per acre of warmouths.

ably were much below the potential maximum.

In a review of table 7 , this question may immediately arise: If a determination could be made of the maximum poundage of each of several fish species that can be supported individually by a lake, and then if all of these species could be placed together in the lake, what would be the relationship between the maximum poundage of this composite population of fishes that can be supported by the lake and a summation of the maximum poundages of fishes supported by the lake as individual species?

The data in table 7 cannot give a satis- factory answer, but they advance the suggestion that, while the diversification of species may improve the degree of utilization of available food and space and thereby add to the poundage of fish the lake can support, the maximum poundage of a composite population will be considerably less than the summation of the maximum poundages of individual species. Even in a bass-bluegill combination in which, in theory, the young of the bluegills should improve the food supply of bass, there is no evidence from this study that the bass population is able to expand to a poundage significantly greater than the lake supports when bluegills are ab- 
sent. Rather, there is some indication that a large bluegill population has a depressing effect upon the bass population and that interspecific competition may exist.

\section{Bass Spawn Inventory}

The idea for an annual inventory of schools of largemouth bass fry at Ridge Lake originated on May 29, 1941, when the first schools of young of that year appeared. On this date, three separate schools of very small bass fry were located in shallow water close to the inner face of the dam; on May 30, what appeared to be the same schools were found in about the same locations, and several other schools were found in other parts of the lake.

From May 30 to June 7, 19+1, a daily search for schools of largemouth bass fry was made. Two men in a small rowboat moved slowly around the lake shallows, one man rowing the boat backwards (stern foremost), and the other standing up in the stern for maximum vision. In this way, it was possible to spot the schools in the clear water at distances of about 25 feet and, at closer range, to make rough estimates of the total numbers of fry in the schools and to plot on a map of the lake the approximate position of each school.

On each succeeding day after May 29, the count of schools and the estimate of fry increased, until, on June 5, 38 separate schools were counted. (The fry in these schools had been spawned from survivors of the 100 sexually mature bass placed in the lake on April 30 and May 1, table 2.) On June 6, 26 schools were counted, and, in addition, many small groups of fry were seen scattered along the shore shelf, * indicating that some of the schools had broken up. On June 7, larger numbers of fry were observed scattered along the shore shelf than had been seen on the previous day, and fewer schools were enumerated. School counts were discontinued June 7.

* A shore shelf is a narrow ledge of earth cut by wave action at the water line in parts of the lake where the slope of the natural bank is steep. Water over this shelf varies between one-half and 2 inches in depth, and small fish, when over the slielf, are relatively safe from larger fish.
The figure accepted as the estimated number of bass fry for the spawning season, table 9 , was the number for June $5,76,000$, the highest number recorded for any single day of the spawning season.

This technique of counting schools of bass fry and estimating numbers of young fish cannot be depended upon to give more than a very rough measure of the success of spawning at Ridge Lake for any given year. It is based on the assumption that all mature bass inhabiting this small body of water reach a condition of ripeness and spawn within a period of a few days. If eggs were deposited over a period longer than 6 or 7 days, the first eggs deposited would hatch, the young would school, and the schools would break up before the last nests of eggs were hatched. Once the fry in the schools begin to scatter, it is difficult to estimate the numbers of young, although a rough census of scattered fry can be made at Ridge Lake by counting small groups of fry along the shore shelf.

The estimates made of the numbers of bass fry in the individual schools are probably conservative. It was not considered desirable to capture and count these young fish, and visual estimates of numbers leave much to be desired. In the Ridge Lake censusing, no schools of fry were estimated to contain more than 3,000 fish, with the exception of one huge school found around the concrete spillway tower in 1951. The estimates for most schools ranged below 2,000 .

Most schools of bass fry were found near shore in water of 1 to 6 feet in depth. A few were found well out from shore in the open water of the lake. Ordinarily, the schools of fry were seen fairly close to the surface of the water. Occasionally they were observed to sound and disappear from view for several minutes before reappearing near the surface. Most of the censusing work was done within a strip of water extending about 35 feet out in the lake from the water edge, and it is probable that some schools, ranging farther out, were missed. On each day of censusing, some schools may have escaped being censused because they were submerged.

The efficiency of censusing may be reduced by turbid waters, floating mats of 
algae, and rooted aquatic vegetation, either submergent or emergent. For example, in $19+4$, when the spawn estimate was only 1,000 fry, table 9, and in 19+9, when it was 24,000 , the censusing operation was handicapped by mats of Hoating algae. In both of these years, the enumeration of young bass was continued, after the schools had broken up, by connting the fry scattered along the shore shelf. In $19+5$, when the peak spawn was recorded, few Hoating algae were present, but dense beds of submerged aquatic plants (not at the time reaching the surface) were in the lake. In $19+6$ and in 19+7, turbid water during the height of the spawning seasons so reduced the visibility that not until 3 or 4 days after the first schools were observed was it possible to make a comprehensive census.

Despite many possible sources of inaccuracies, the fairly uniform technique of censusing that was continued each year after it was established in $19+1$ gave comparative data that are very useful. The results of bass fry estimates, 1941 through 1950 , were reported in a previous paper (Bennett 1951:237) and are repeated in table 9 , along with an estimate of the 1951 spawn and the actual dates when the first schools of bass fry were seen in each year. Table 9 has been set up in two sections to emphasize the strik- ing difference in the abundance of spawn between years in which the population was culled of small "yearling" fish (fish spawned the previous year) and years in which many of these fish were present.

Although the numbers shown in table 9 may be far from accurate, if these numbers are taken as indices of the relative abundance of young bass from year to year, it is believed that they are highly significant. In 19+1, when the lake was first stocked with adult bass and in years when the lake was drained and restocked with only the larger fish, the average of the estimated numbers of fry $(50,500)$ was about 8.6 times the average of the estimated numbers of fry found in alternate years when the lake was not drained and the fish population was not culled of small "yearling" fish. The difference between average numbers would have been much greater if the spawn count of 1942 had been omitted. The "yearling" fish present in 1942 (largely bass ranging in size from 6 to 11 inches) averaged larger than those present in any other comparable year $(1944,1946,1948$, or 1950). These bass were little interested in nest robbing or in predation on fish of fry sizes. They decimated the 1942 spawn, but their predation is believed to have taken place after the 1942 bass fry had grown to fingerling sizes.

Table 9.-Estimates of numbers of largemouth bass fry to reach schooling stage in years in which Ridge Lake fish population was culled of small "yearling" fish (fish spawned the previous year) in spring draining censuses, and similar estimates in years in which no draining censuses were made and many small "yearling" fish were present. The earliest dates on which bass fry were observed are listed.

\begin{tabular}{|c|c|c|c|c|c|}
\hline \multicolumn{3}{|c|}{$\begin{array}{c}\text { 1)ata for Years in Which Sitall "Yearling" } \\
\text { Fish Were Removed IN SPring Draining } \\
\text { Censuses }\end{array}$} & \multicolumn{3}{|c|}{$\begin{array}{c}\text { Data for Years in Which Small } \\
\text { "Yearling" Fish WVRe Present; Lake } \\
\text { Not Drained }\end{array}$} \\
\hline Year & $\begin{array}{c}\text { Fstimated Number } \\
\text { of } \\
\text { Bass Fry }\end{array}$ & $\begin{array}{l}\text { Earliest Date } \\
\text { of } \\
\text { Fry Appearance }\end{array}$ & Year & $\begin{array}{c}\text { Estimated Number } \\
\text { of } \\
\text { Bass Fry }\end{array}$ & $\begin{array}{l}\text { Earliest Date } \\
\text { of } \\
\text { Fry Appearance }\end{array}$ \\
\hline $\begin{array}{l}1941 \ldots \\
1943 \ldots \\
1945 \ldots \\
1947 \ldots \\
1949 \ldots \\
1951 \ldots \\
\text { Total...... } \\
\text { Average. }\end{array}$ & $\begin{array}{r}76,000^{1} \\
18,000^{1} \\
116,000 \\
37,000 \\
24,000 \\
32,000 \\
303,000 \\
50,500\end{array}$ & $\begin{array}{l}\text { May } 29 \\
\text { June } 10 \\
\text { June } 3 \\
\text { June } 4 \\
\text { June } 3 \\
\text { May } 25 \\
\text { - }\end{array}$ & $\begin{array}{c}1942 \\
1944 \\
1946 \\
1948 \\
1950 \\
-\end{array}$ & $\begin{array}{c}26,000^{1} \\
1,000^{2} \\
2,500 \\
0^{2} \\
0^{2} \\
-\quad \\
29,500 \\
5,900\end{array}$ & $\begin{array}{l}\text { May } 14 \\
\text { June } 4 \\
\text { June } 5 \\
\text { None } \\
\text { None } \\
- \\
-\end{array}$ \\
\hline
\end{tabular}

1 Few fish other than largemouth bass were present in the lake.

2 No schons of young bass could be found in 1948 and 1950 . Extensive seining with a minnow seine produced no small bass in 1948; in 1950, one small bass was taken in one of five minnow seine hauls in the upper part of the lake. 
Although, in 1948 and 1950 , conditions were relatively good for censusing, no schools of bass fry were observed in either year. In 1948 , a careful search was made for fry and fingerlings at approximately 2-day intervals trom May 28 to June 20. The search included the area along the shore shelf late in this period, when schools, if they existed, should have broken up. "Yearling" bluegills and bluegill fry were abundant in all parts of the lake. On July 7, six hauls with a quarter-inch-mesh minnow seine in six locations in the upper end of the lake brought up hundreds of "yearling" bluegills and bluegill fry but not a single tingerling bass.

In 1950, the search for bass fry and fingerlings extended over approximately the same period as in 19+8 (May 29 to June 12), with results approximating those of 1948. One bass fingerling was taken in one of five minnow-seine hauls made in the upper part of the lake on June 25 , indicating that a few young bass of the current spawn were present in the lake. Small bluegills were numerous in these seine hauls, in spite of the fact that an attempt had been made to eradicate the bluegill population from the lake at the time of the 1949 census.

In 1951, bass fry first were observed on May 25, when six schools that were located contained an estimated 16,000 fish. 'The maximum count was made on May 29: 12 schools containing an estimated 32,000 fry. On this date, the largest school of bass fry ever observed at Ridge Lake was found over deep water ( 14 to 20 feet) around the concrete spillway tower near the dam. This school extended completely around three sides of the tower, a linear distance of about 30 feet, and was approximately 8 feet broad throughout its extent. It was estimated to have contained 10,000 bass, and it remained close to the tower until it began to break up on June 2. Only a remnant of this school could be found around the tower on June 6 .

\section{Spawning Success and Population Density}

Few persons will question the assumption that variations in the physical and chemical characteristics of an aquatic environment during the time that fish are spawning may influence the success of spawning. Sudden fluctuations in water levels, in turbidity and rate of silting, in dissolved salts, and in temperature have singly, or in combination, been held responsible for good or poor production of young.

Little has been published, however, on the relationship between the composition and density of a fish population and the success of the spawning attempts of one or several species comprising that population. In my opinion, information on this relationship is of great importance in the management of lakes for angling, because of the probability that the disappearance of a species considered of high value for angling may be associated with the inability of that species to produce a successful spawn under certain types and degrees of competition.

At Ridge Lake, fairly reliable population estimates of fish larger than 3 inches long could be made at any given bass spawning period. Estimates of population could then be compared with inventories of schooling bass fry.

Population estimates of fish, not including those fish of less than 1 year of age, were made as follows: For any given year of the series of years beginning with 1941, when the lake was stocked, and continuing in $19+3,19+5,19+7,19+9$, and 1951 , when it was restocked following draining in March, the population estimate included only the fish actually placed or replaced in the lake in that year (except for $19+3$ when an estimate of the number of unmarked bass was added, table 5 , note 1). For any given year of the series of years 1942, 19t4, 1946, 1948, and 1950 , the population estimate included all fish, except those spawned in the given year, that were recovered in the draining census of the following spring; to these were added the fish recorded as being caught by fishermen during the summer of the given vear, which were obviously in the lake at spawning time of that year. These estimates do not include fish lost from the population through natural mortality and from such causes as death resulting from undetected injury during the previous censusing operation, escape over the spill- 
way, or poaching. Although it is recognized that the population estimates and inventories of spawn at Ridge Lake are far from exact, it is believed that both have value hecause of a year-to-year uniformity of technique used in gathering data.

Table 10 shows the total numbers per acre of largemouth bass, bluegills, and other fish (mostly green sunfish and black of 6 inches in length are capable of spawning. Fish of this species 3 inches in length or longer may feed on bass fry:

In 1941, at the time 100 bass of spawning age were placed in Ridge Lake, the lake area was only about 9 acres, giving an assumed adult population of 11 bass per acre. The resulting spawn was the second largest recorded and the largest per acre: 38 broods estimated at 76,000

Table 10.-Estimated numbers of largemouth bass, bluegills, and other fish per acre shortly prior to spawning time, and of largemouth bass fry at spawning time, for each of the years 1941-1951 at Ridge Lake. Calculations involving acreage were hased on a water area of 18 acres except where stated otherwise.

\begin{tabular}{|c|c|c|c|c|c|c|c|c|c|}
\hline \multirow{2}{*}{$Y_{E A R}$} & \multicolumn{2}{|c|}{$\begin{array}{c}\text { L. ARGEMOUTH } \\
\text { BASS, } \\
\text { PER ACRE }\end{array}$} & \multicolumn{2}{|c|}{$\begin{array}{l}\text { BLUEGILLS, } \\
\text { PER ACRE }\end{array}$} & \multicolumn{2}{|c|}{$\begin{array}{c}\text { Other Fish, } \\
\text { Per ACre }\end{array}$} & \multicolumn{2}{|c|}{$\begin{array}{l}\text { AlL Fish, } \\
\text { PER ACre }\end{array}$} & \multirow{2}{*}{$\begin{array}{l}\text { Estimated } \\
\text { Bass Fry, } \\
\text { PER ACrE }\end{array}$} \\
\hline & $\begin{array}{c}\text { Ten } \\
\text { Inches } \\
\text { or } \\
\text { Longer }\end{array}$ & $\begin{array}{c}\text { Less } \\
\text { Than } \\
10 \\
\text { lnches }\end{array}$ & $\begin{array}{l}\text { Six } \\
\text { Inches } \\
\text { or } \\
\text { Longer }\end{array}$ & $\begin{array}{c}\text { Less } \\
\text { '1han } \\
6 \\
\text { Inches }\end{array}$ & Large & Small & Large & Small & \\
\hline 1941 & $11^{1}$ & - & - & - & - & - & 11 & - & 8,444 \\
\hline 1942 . & $24^{2}$ & 266 & - & - & 2 & - & 26 & 266 & 1,444 \\
\hline 1943. & 6 & 104 & - & - & - & - & 6 & 104 & 1,000 \\
\hline 1944. & 57 & 33 & - & - & 29 & 15 & 86 & 48 & 56 \\
\hline 1945. & 36 & - & 3 & - & - & - & 39 & - & 6,444 \\
\hline 1946. & 34 & 53 & 476 & 2,858 & 17 & 32 & 527 & 2,943 & 139 \\
\hline 1947. & 22 & & 98 & - & - & - & 120 & - & 2,056 \\
\hline 1948. & 77 & 72 & 299 & 1,120 & 16 & 4 & 392 & 1,196 & 0 \\
\hline $1949^{3}$ & 70 & $23^{4}$ & - & - & - & - & 93 & $1, \ldots$ & 2,182 \\
\hline 1950. & 42 & 31 & 58 & 2,878 & 20 & 56 & 120 & 2,965 & \\
\hline 1951. & 29 & $16^{5}$ & 36 & & $3^{6}$ & $31^{6}$ & 68 & & 1,778 \\
\hline
\end{tabular}

${ }^{2}$ Calculations for this year based on actual water area (about 9 acres) at spawning time.

2 Figure includes only 3 bass of spawning age per acre.

Calculations for this year based on actual water area (about 11 acres) during summer.

None less than 9 inches long.

8 None less than 8 inches long.

- Warmouths only.

bullheads) for each year, along with an estimate of the bass spawn per acre. Bass are separated into those of 10 inches in length or larger and those smaller; bluegills into those of 6 inches in length or larger and those smaller.

In a study of the relationship between population density and spawning success, consideration should be given to the spawning and feeding habits of the species involved.

In Illinois and other northern states, largemouth bass of 10 inches or more in length may not be capable of spawning unless they are at least 2 years old. Fish of this species larger than about 7 inches in length are usually not interested in food items as small as bass fry. Bluegills fry $(8,4+4$ per acre, table 10$)$. The relatively sparse population of adult bass had little or no interference with their spawning.

Forty of the bass placed in Ridge Lake in 1941 were recorded as being caught by fishermen after June, 1942, table 19. Seventeen were taken in the first draining census, in 1943, table 4. So at least 57 of the original Ridge Lake bass must have been present during the 1942 spawning period (about 1.3 per cent of the bass taken in the $19+3$ draining census, table 4). These 57 bass, plus a large number of "yearling" bass 5 to 11 inches in length, made up most of the 1942 population prior to spawning time; this population is calculated to have averaged 290 
bass per acre, table 10. Fourteen schools of fry were counted on May 29; they were estimated to contain 26,000 young fish $(1,+4+$ per acre). No larger counts were made after this date. The smaller number of broods in $19+2$ than in 1941 may have been due to a smaller number of spawners, to interference with their spawning by "yearling" bass, or to a less favorable spawning season. Very few bass of the $19+2$ brood appeared in the $19+3$ draining operation. From this fact it was assumed that most of them became food for the $19+1$ brood during the summer.

With the removal of 2,783 small bass of the $19+1$ brood in the spring of $19+3$, the population was reduced by more than 50 per cent, tables 3 and 4 . Bass of the $19+1$ brood were old enough to spawn in $19+3$, but many were rather badly stunted. The sexually mature bass, which included 15 of the original stock, produced a relatively small spawn estimated at 18,000 fry $(1,000$ per acre, table 10$)$.

In 19+4, Ridge Lake contained a relatively large population of adult bass. Attempts to census the young were only moderately successful (page 246) ; the highest estimate of young seen on any one day never exceeded 1,000, or about 56 per acre, table 10.

In the years when the fish population of Ridge Lake during the bass spawning season was one essentially of largemouth bass only (19+1-19+4), the bass spawn became progressively smaller each year, although in each year some spawn was produced, table 10. Bluegills were introduced into Ridge Lake after the bass spawning season of 1944, and, when the lake was drained in the spring of $19+5$, only large bluegills were replaced in the lake along with all of the legal-length bass, table 5. Several hundred bluegill fry produced in late summer of 1944 undoubtedly escaped the census by remaining in the stream channel and in pools within the lake basin when the draining operation of $19+5$ was completed. These later escaped to the lake as it refilled.

The bass spawn of 1945 was the largest ever produced after the lake basin was full-an estimated 116,000 fry $(6,4+4$ per acre, table 10), spawned by a population of 36 adult bass per acre, table 5 . However, on a per-acre basis, the $19+5$ spawn was not as large as that of $19+1$, when the lake area was about 9 acres. From the $19+7$ draining census, table $t$, it is evident that the 61 adult bluegills returned to the lake in $19+5$ and their progeny of $19+4$ that escaped the 1945 census produced large numbers of young in 1945 and 19+6. Moreover, the survival rate of the young bluegills must have been high in spite of the presence of unusually large numbers of small bass. These young bass might have been expected to control the survival of bluegill fry in $19+5$ and 19+6, but it is evident that they did not.

At the beginning of the spawning season of 19+6, Ridge Lake contained a large population of both bass and bluegills, plus somewhat larger populations of bullheads and green suntish than had been present in previous years. 'The estimated total population of fish was 3,470 per acre in $19+6$ prior to spawning and the bass spawn was estimated to be about 139 fry per acre, table 10 .

The 1947 spawn of bass was estimated at 2,056 fry per acre, table 10 . Following the draining census in March, 392 legalsized bass and 1,761 large bluegills had been returned to the lake, table 5 , giving a population of 120 fish per acre. The $19+7$ bass spawn per acre was much smaller than that of $19+1$ or $19+5$ and slightly smaller than that of $19+9$, but larger than that of other years, table 10 .

There was no visible indication that bass fry developed to the schooling stage in 1948 or 1950 . In $19+8$, several adult female bass caught by Natural History Survey personnel early in June contained well-developed eggs; female bass caught by anglers later, after the lake was opened to fishing, appeared to be spent. Yet no schools of bass fry were seen by Survey personnel in making daily trips around the lake, and no young bass were taken in extensive seining in the shallow upper end of the lake. Yearling bluegills and bluegill fry were abundant.

An estimate of the 1948 fish population, based on the anglers' catch of 1948 and the $19+9$ census, gave $1+9$ bass and $1,+19$ bluegills per acre, table 10 . This is a large population but considerably less than that of $19+6$, when the lake contained 3,470 fish per acre ( 87 bass, $3,33+$ bluegills, and 49 other fish). 
In 1949, 1,027 bass were returned to the lake following the March census, table 5 , about $25 /$ of which were between 9 and 10 inches in length. The lake area by Junc 1 was only 11 acres. An attempt had been made to remove all bluegills in March. After the census, the bass population, which had developed in 18 acres of water with a large available food supply in the form of crayfish, bluegills, and aquatic insect nymphs, was concentrated into 11 acres of water containing a much reduced food supply. Bass caught throughout the summer were thin, and many of those less than 10 inches long in March were still below that length when caught in July and August. 'The bass spawn was relatively small; the estimate was 24,000 fry $(2,182$ per acre, table 10$)$.

In 1950, small bluegills were again abundant, most of them having originated from the 1949 spawn of those fish that had remained in the lake basin during the 1949 draining operation. The estimated population of small bluegills was $2,87 \mathrm{~S}$ per acre; this was comparable to the number present in 1946 and more than twice the number present in 1948, tab?e 10. However, in 1948 the large bluegills numbered 299 per acre as compared with 58 in 1950. In 1950, as in 1948, the survival of bass to the fry stage apparently was very low.

The number of bass replaced in the lake after the 1951 census amounted to 29 large fish per acre, plus an additional 16 per acre that ranged between 8 and 10 inches long, a total of 45 per acre, table 5 . 'The bluegills replaced averaged 36 large fish per acre. The large warmouths replaced averaged about 3 per acre and the small warmouths 31 per acre. Small warmouths were replaced in an attempt to build up the population of these fish. In this year the estimated number of bass fry produced per acre amounted to more than 1,700 , table 10 .

Several factors related to density of population appear to have influenced the production of largemouth bass spawn. During the years 1941 to 1944 , inclusive, when the fish population was essentially one of largemouth bass alone, the spawn estimate decreased each year without any apparent relationship to the number of hass of spawning age present in the lake.
Later, when bluegills were present, the years of good spawn production were those in which the bluegill population (particularly of small fish) was greatly reduced at the time of the spring draining census $(1945,19+7,1949,1951)$. There is strong evidence here that a large bluegill population may control the survival of the spawn of bass $(1946,1948,1950)$. If this relationship of bass with a crowded bluegill population were allowed to continue over a period of years, the bass population might become gradually smaller because of the lack of adequate replacement for the adults lost. Interference with spawning and attacks on bass eggs and fry by small fish (of other species as well as the bluegill) may be the most inportant single factor responsible for poor bass populations and poor bass fishing in Illinois lakes.

The level of survival of young bass throughout the first year of life may not be correlated very closely with the level of spawn production. In 1942 and 19+3, moderate numbers of young were observed, but age determinations made from scales removed from bass taken by fishermen and from bass handled during the draining censuses in later years indicated that very few fish of the 1942 and 1943 broods survived the postfry stage. In 1946, the number of bass fry was relatively small, but quite a number of fish from the brood of this year appeared in the catches of later years, in spite of the fact that this brood could have been eliminated entirely through draining operations of March, 1947. Bass of the 1946 brood that appeared in the catches of 1947 and 1948 and as unmarked fish in the 1949 draining census must have remained in the lake basin or in the feeder stream above the lake during the 1947 census.

How often must a successful spawn be produced to maintain a largemouth bass population that approaches the maximum a body of water will support? At Ridge Lake the bass population was maintained at a high level throughout most of the 10-year study period by relatively good spawns in most odd-numbered years (1941, 1943, 1945, 1947, 1949, and 1951) alternating with relatively poor spawns in most even-numbered vears $(1944,1946,1948,1950)$, table 9. In 
this 10-year period small bass were removed in draining censuses and, from the summer of $19+6$ on, by fishermen.

A relatively small number of fish are required to replace those taken by fishermen or lost through natural mortality and other causes of death. That even this relatively small number may not be produced, or may not survive the period of census made approximately 21 months after the spawn appeared. The captured bass were fish, 6 to 12 inches in length, that had survived long enough to grow to sizes too large for "easy" predation. The most favorable calculated survival ratios of number of fry to number of bass subsequently captured were 29 to 1 for $19+1$ and 30 to 1 for $19+7$; the $19+3$ and $19+9$

Table 11.-Estimated number of largemouth bass fry in each of five year-classes or broods produced by the original stock in Ridge Lake and by adult bass returned to the lake following draining censuses, the number of bass of designated year-class taken by fishermen in the next two fishing seasons after spawning, plus those taken in the next draining census about 21 months after spawning, and the ratio of spawn to fish subsequently taken. Calculations involving acreage were based on a water area of 18 acres except where stated otherwise.

\begin{tabular}{|c|c|c|c|c|c|}
\hline \multirow{2}{*}{$\begin{array}{c}\text { YEAR-Class } \\
\text { OR BROOD }\end{array}$} & \multirow{2}{*}{$\begin{array}{c}\text { Estimated } \\
\text { Number of } \\
\text { Fry, PER ACre }\end{array}$} & \multicolumn{3}{|c|}{$\begin{array}{c}\text { Number, Per Acre, of Bass of } \\
\text { Designated Year-Class Taken } \\
\text { in The } 21 \text { Months Succending } \\
\text { Spawning }\end{array}$} & \multirow{2}{*}{$\begin{array}{l}\text { Ratio of } \\
\text { SPAWN To } \\
\text { SuBSEQUENI } \\
\text { 'TAKE }\end{array}$} \\
\hline & & By Fishermen & $\begin{array}{c}\text { In Draining } \\
\text { Census }\end{array}$ & Total & \\
\hline $\begin{array}{l}1941^{1} \ldots \ldots \ldots \\
1943 \ldots \ldots \ldots \\
1945 \ldots \ldots \ldots \\
1947 \ldots \ldots \ldots \\
19493 \ldots \ldots \ldots\end{array}$ & $\begin{array}{l}8,444 \\
1,000 \\
6,444 \\
2,056 \\
2,182\end{array}$ & $\begin{array}{l}28 \\
15 \\
17 \\
20\end{array}$ & $\begin{array}{l}266^{2} \\
25 \\
18 \\
51 \\
45\end{array}$ & $\begin{array}{r}294 \\
25 \\
33 \\
68 \\
65\end{array}$ & $\begin{array}{r}29 \text { to } 1 \\
40 \text { to } 1 \\
195 \text { to } 1 \\
30 \text { to } 1 \\
34 \text { to } 1\end{array}$ \\
\hline
\end{tabular}

1 Calculations for this year based on actual water area (about 9 acres) at spawning time.

2 Figure includes an estimated 473 bass that escaped the 1943 census.

3 Calculations for this year based on actual water area (about 11 acres) during summer.

high vulnerability to predation, is suggested by the spawn inventories of 1948 and 1950 , table 9 , and the almost complete disappearance of the large number of bass fry produced in 19+2. Largemouth bass are capable of rapid growth. Thus, if small bass are available, the replacement of a large loss among bass of desirable sizes may take place in a comparatively short time.

With estimates of the numbers of bass spawned and with age determinations of the bass taken by fishermen and in draining censuses, it is possible to show the relationship between the number of fry in each brood and the subsequent catch of members of the brood as larger fish. In table 11 are shown estimates of the numbers of bass fry per acre appearing in the years $1941,19+3,1945,1947$, and 1949; for each brood or year-class, the number of bass taken by angling in the year of the spawn and the year following; and also the number taken in the draining ratios of 40 to 1 and $3+$ to 1 , respectively, were only slightly less favorable. The poorest survival occurred in the 1945 brood, in which the ratio was 195 fry to 1 bass recovered. All of these survival ratios may have represented a higher rate of survival than would have occurred had the same numbers of schooling fry (as estimated in table 11) been subjected to predation from more nearly "normal" (unculled) populations of fishes.

\section{Growth of Bass}

At Ridge Lake the permanent removal, or culling out, of small fish by the Natural History Survey staff during draining operations in alternate years and by anglers during most fishing seasons reduced competition for food among surviving fish in the lake and thereby allowed for relatively rapid growth.

If all bass of less than 8 to 10 inches in length could have been permanently 


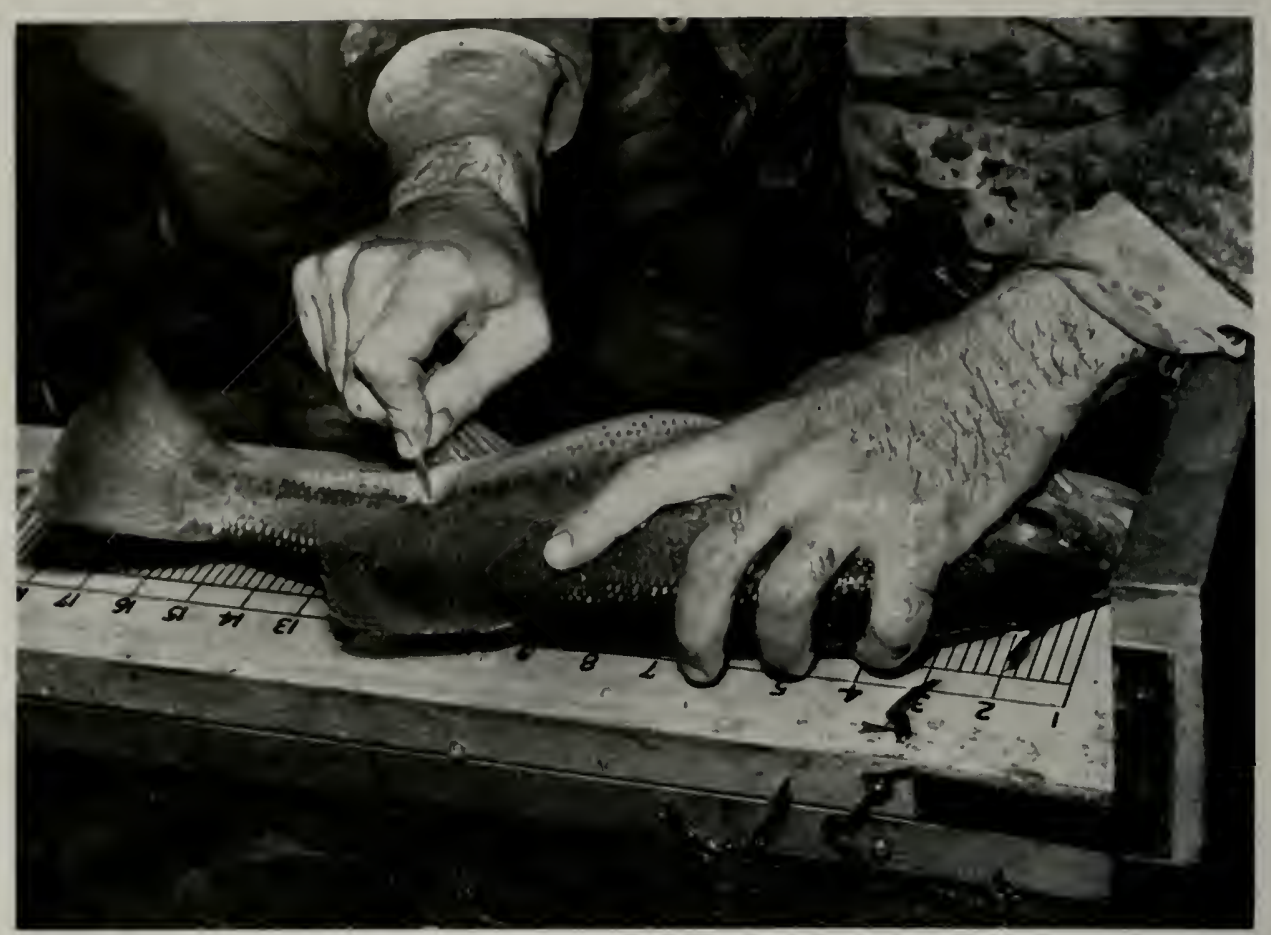

Fig. 12. - Taking a sample of scales from largemouth bass handled in Ridge Lake draining census. Scales collected from bass and bluegills taken in draining censuses or caught by anglers were placed in small envelopes and later used for aging these fish.

removed from the lake at 2-year intervals, selection would have heen continuously in favor of the rapidly growing fish. However, in each year the lake was drained, some small bass remained in the lake basin and survived by staying either within the blind end of the old stream channel near the dam or in undrainable water pockets that appeared in the lake bottom as a result of uneven deposition of silt. After water was again impounded behind the dam, these bass escaped to mingle with the population of selected fish that were returned to the lake. Probably many of the escaped fish were eaten by the larger returned fish, but those that survived found conditions optimum for rapid growth. On the next census 2 years later, they made their appearance as the larger individuals of the group of unmarked fish.

During the period 1941-1951, scale samples, fig. 12, were collected from,+ 305 hass that were taken by fishermen or that were returned to the lake following draining censuses. Later these bass were aged and separated into broods (year-classes). Growth curves were constructed for the individual broods by use of the average lengths of the fish at the time of capture. The growth curves for 4,273 of these fish are shown in fig. 13. The numbers of fish in the year-classes represented in this figure are given here: $1941,1,780$ fish; $194+, 96$ fish; 1945,580 fish; 1946, 286 fish; 1947, 1,038 fish; 1948, 203 fish; and 1949, 290 fish. The 1942 and 1943 broods were represented by only 17 and 15 fish, respectively, too few for use in the construction of valid growth curves for these broods. Average lengths of 1941 brood bass in 1942 were hased largely on fish of legal length kept by anglers; therefore the growth curve for the 1941 brood in $19+2$ is not truly representative.

The evidence furnished by the $19+2$ creel, the 1943 draining census, and fish samples taken by Natural History Survey staff members in 1943 indicates that, even after drastic thinning in 1943, the $19+1$ brood of bass dominated the fish 


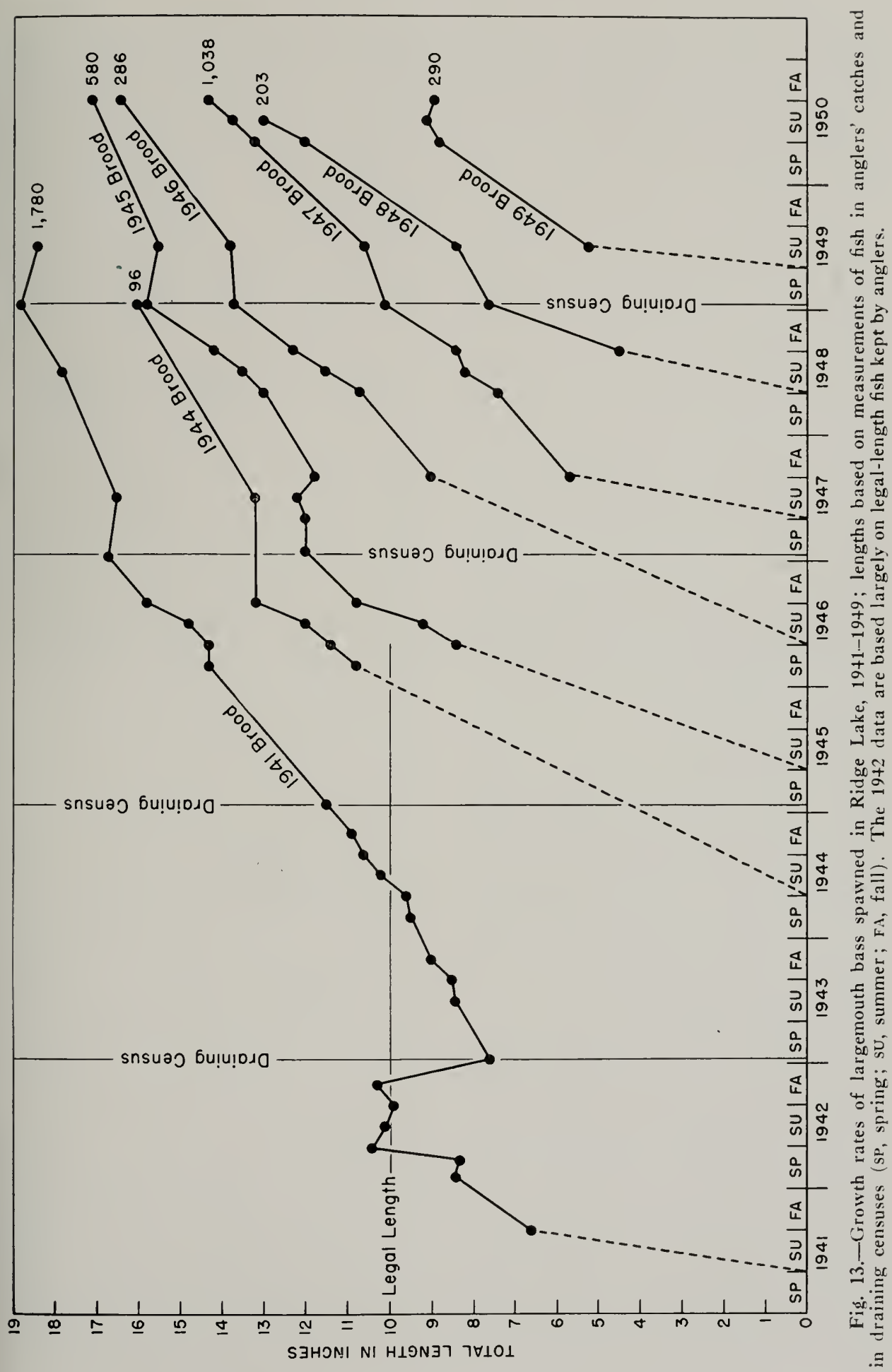


population of the lake. The survival of spawn in 19+1 was very high, and the new lake contained adecuate forage for these simall bass throughout the $19+1$ growing season, so that their growth rate in $19+1$ was rapid, table 12 , even though the lake basin did not completely fill until December.

In four collections in the spring of $19+2$, consisting of a total of 148 fish, 21.6 per cent of the bass were 10 inches or longer; on the basis of this sample, it was decided to open the lake to fishing in the summer of that year.

In the fishing season of 19+2, anglers took 323 bass of 10 inches or longer belonging to the $19+1$ brood, table 6 , and released 3,60t smaller fish they had caught. Apparently the larger fish were the cannibals of the brood. It was not until the draining census of $19+3$, after the fish of the $19+1$ brood had completed two growing seasons, that the average length in the brood could be placed accurately; it was 7.6 inches, table 13 . Scale studies support the hypothesis that most of this growth was made in $19+1$ and that the fish remained about the same size throughout 19+2. Growth was resumed in the $19+3$ season at a relatively slow rate, following the spring reduction in population. It was not until late in the summer of $19+t$ that a large part of the $19+1$ brood exceeded the 10 -inch length. In the draining census of $19+5$, after four growing seasons, this brood averaged only 11.5 inches total length. The condition of overpopulation and stunting of bass that existed in Ridge Lake early in 1942 might have been quickly rectified had fishermen heen allowed to take the $3,60+$ bass of less than legal length (10 inches) that were caught and released in that year.

As mentioned in the section "Spawning Success and Population Density," very few bass of the $19+2$ and $19+3$ broods survived the postfry stage. The first brood of bass after that of $19+1$ to be represented in anglers' catches by fair numbers of fish was that of 194t. Ninety-two fish of this brood unexpectedly appeared as unmarked individuals in the hook-and-line catch of 1946. The survival of 1944 brood fish, supposedly removed from the lake in the draining operation of $19+5$, may be theorized as follows: Bass of the
$19+1$ brood were about 10 inches in length in $194+$ and were not particularly interested in bass fry as food. Few bass of smaller sizes (19+2 and $19+3$ broods) were present. Bluegills were placed in the lake in June of that year and immediately produced a large spawn. The small bluegills may have acted as a buffer, reducing bass predation on bass. The upper

Table 12.-Numbers of 1941 brood of large. mouth bass of various lengths taken with fly-rod lures at Ridge Lake, on August 20 and on October 14 and $21,1941$.

\begin{tabular}{|c|c|c|}
\hline $\begin{array}{l}\text { Total } \\
\text { LeNGTh, } \\
\text { INChES }\end{array}$ & $\begin{array}{l}\text { Number } \\
\text { Taken, } \\
\text { August } 20\end{array}$ & $\begin{array}{l}\text { Number } \\
\text { TAKEN, } \\
\text { OCTOBER } \\
14 \text { AND } 21\end{array}$ \\
\hline 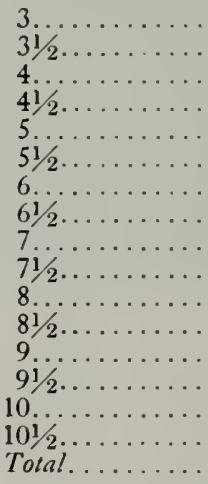 & $\begin{array}{r}0 \\
1 \\
3 \\
2 \\
1 \\
1 \\
9 \\
11 \\
9 \\
5 \\
6 \\
2 \\
0 \\
0 \\
0 \\
0 \\
50\end{array}$ & $\begin{array}{r}0 \\
1 \\
2 \\
9 \\
1 \\
0 \\
4 \\
1 \\
2 \\
5 \\
9 \\
11 \\
20 \\
9 \\
7 \\
2 \\
83\end{array}$ \\
\hline
\end{tabular}

part of the lake had developed a dense stand of the pondweed, Potamogeton foliosus, and other plants into which some of the 1944 brood bass moved and lived throughout the summer. Individuals of this group made poor growth (as shown by the scale pattern of the brood) because of food competition among the fish within the mass of plants. At the end of the first growing season most of these bass were less than 2 inches in length (calculated from scale measurements at later dates).

Some of the small bass of the $19+4$ brood escaped the 1945 draining census by remaining in pools or in the blind stream channel between the mouth of the diversion ditch and the dam until after the draining census was completed and water was again impounded. These fish then escaped from the confines of the blind stream channel or the pools. As 
Table 13.-Average total lengths of largemouth bass at, or approximately at, ends of named growing seasons, Ridge Lake, 1941-1949.

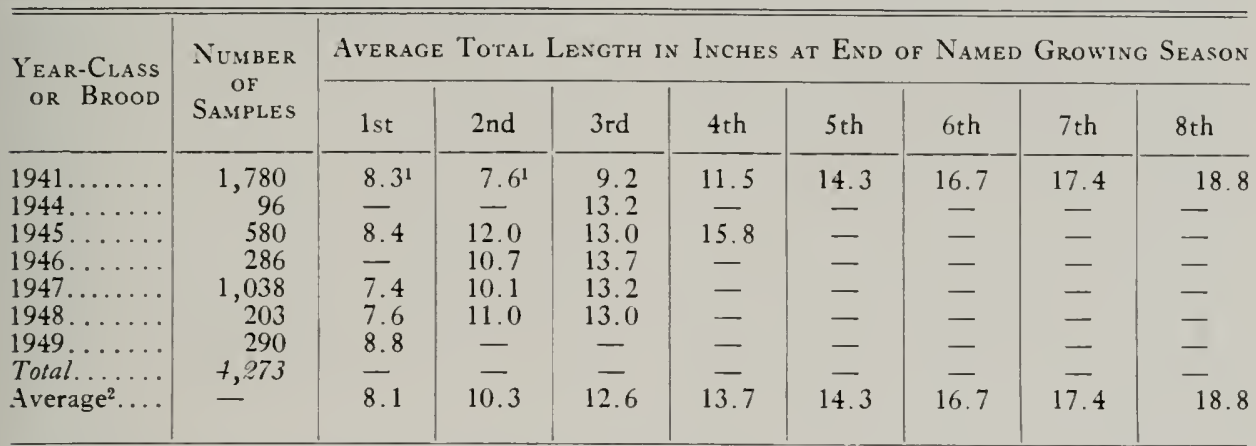

1 Average for end of first growing season based on small number of samples taken by angling. Average for end of second growing season based on fish taken in 1943 draining census.

2 Average of average lengths at ends of named growing seasons.

soon as the fry of the $19+5$ spawn appeared, the escaped fish had an abundance of food available to them. After June of 19+5, they made rapid growth, and in $19+6$, when they were caught as unmarked fish, they ranged from 10.5 to 13.5 inches in length (the scales indicated a 7- to 11inch increment for 1945).

The ability of the $19+1$ hrood of bass to curtail the survival of postfry bass seems to have been lost in $19+4$, and no brood produced from $19+4$ on was able to control the survival of young bass to an extent comparable to the control exercised by the $19+1$ brood in $19+2$ and $19+3$.

In spite of the relatively small bass spawn observed in 1946, and the apparent absence of surviving bass spawn in $19+8$, the $19+6$ brood was represented in scale collections by 286 fish and the 1948 brood by 203 fish, table 13.
Scale studies indicated that although the numbers of spawn surviving in years in which the lake was not drained were relatively small, they contributed in some degree to the numerical size of the bass population in later years.

Plateaus in the growth curves in fig. 13, corresponding to early summer periods following March drainings, suggest that the draining operations greatly reduced the food resources of the lake for the large bass replaced in it, and that, in spite of the fact that the poundage of bass returned after each draining census was smaller than that taken in the census, several months were required before the fish resumed their growth. In 1949, the food shortage was more severe than usual because the lake basin failed to refill completely until fall.

The average lengths attained by indi-

Table 14.-Average total lengths of bluegills at, or approximately at, ends of named growing seasons, Ridge Lake, 1944-1949.

\begin{tabular}{|c|c|c|c|c|c|c|}
\hline \multirow{2}{*}{$\begin{array}{l}\text { YEAR-CLASS } \\
\text { OR BROOD }\end{array}$} & \multirow{2}{*}{$\begin{array}{l}\text { Number of } \\
\text { Samples }\end{array}$} & \multicolumn{5}{|c|}{$\begin{array}{c}\text { Average Total Length in Inches at End of Named } \\
\text { Growing Season }\end{array}$} \\
\hline & & $1 \mathrm{st}$ & 2nd & 3 rd & 4 th & 5 th \\
\hline $\begin{array}{l}1944 \ldots . . . \ldots \\
1945 \ldots \ldots \\
1946 \ldots \ldots \\
1947 \ldots \ldots \\
1948 \ldots \ldots \\
1949 \ldots \ldots \\
\text { Total. . . . . . . . . . . . . . } \\
\text { Average }\end{array}$ & $\begin{array}{r}15 \\
1,304 \\
267 \\
106 \\
44 \\
211 \\
1,947 \\
-\end{array}$ & $\begin{array}{l}\overline{5.8} \\
- \\
\overline{3.6} \\
\overline{-} \\
4.7\end{array}$ & $\begin{array}{l}- \\
6.3 \\
5.6 \\
5.3 \\
7.6 \\
6.4 \\
62\end{array}$ & $\begin{array}{l}6.9 \\
6.5 \\
6.9 \\
8.0^{1} \\
- \\
- \\
- \\
7.1\end{array}$ & $\begin{array}{l}7.5 \\
7.7 \\
- \\
- \\
- \\
7.6\end{array}$ & $\begin{array}{l}7.8 \\
- \\
- \\
- \\
- \\
7.8\end{array}$ \\
\hline
\end{tabular}

Measurements actually taken in May. 1950. beginning of fourth growing season.

Average of average lengths at ends of named growing seasons. 
viduals of the various hroods of bass at or approximately at the ends of the various growing seasons are shown in table 13. Growtl for the first year was fatirly uniform for all broods; average lengths at approximately the end of the year ranged hetween $7 . t$ and 8.8 inches. Growth for the second year was slow for the 19+1 hrood, which was stunted in this year of life, but the average lengths for secondyear bass of other broods ranged between 10.1 and 12.0 inches. All broods except that of $19+1$ attained an average length of at least 13.0 inches the third year, and the $19+5$ brood averaged 15.8 inches the fourth year. After the slow start made by the $19+1$ brood during its first + years, the rate of growth improved, so that, during the next + years, the average weight of individuals of this brood increased from about 1 pound at the beginning of the $19+5$ growing season to about $t$ pounds at the beginning of the 1949 season.

Fishermen prefer to catch large bass but are satisfied with fish of sufficient size to produce an appreciable bend in a fly rod or bait rod. Small bass ordinarily strike more readily than do large ones and for this reason are easier to catch. 'Thus, from the standpoint of bass management, the growth rate of a bass after the fish has reached a catchable size is of secondary importance; the primary objective is to bring the maximum number of bass fingerlings up to sizes attractive to fishermen in the shortest possible time.

\section{Growth of Bluegills}

Except for a short period in 1949, Ridge Lake probably contained fairly large populations of bluegills after the spawning season of $19+5$. In the draining operation of March, 1949, the bluegills were reduced to a low population level because an attempt was made at that time to get rid of them completely.

'The growth rates of the several yearclasses or broods of bluegills produced in the lake have been determined by aging scales from $1,9+7$ of these fish collected in the years 19+6-1950, table 14 .

Growth of the first two year-classes of bluegills produced in the lake was rapid, fig. 14. In the $19+6$ growing season, 1944 year-class fish averaged 6.9 inches total length (at about 32 months of age) and $19+5$ fish averaged 5.8 inches (at about 19 months of age). Bluegills representing $19+6,19+7$, and 1948 year-classes grew less rapidly than those representing preceding year-classes, and fish of each of these year-classes grew at a less rapid rate in their first year than fish of the year-class preceding, fig. 14. Poorest recorded first-year growth occurred in 1948; bluegills spawned in that year averaged only 3.6 inches total length in March, 19+9, before second-year growth had started.

The growth stimulus produced by the severe thinning of the bluegill population in 1949 is shown clearly in the 1947, $19+8$, and 1949 year-classes among fish that were spawned after, or that managed to escape, the draining operation of $19+9$, fig. 14. Bluegills of the 1947 year-class, which averaged 5.3 inches in length in March of $19+9$ (equivalent to end of second growing season), had grown to an average length of 8.0 inches by May of 1950 (shortly after start of fourth growing season); fish of the 1948 year-class, which averaged about 3.6 inches in length after one season of growth, grew to an average length of 7.6 inches before the third growing season was well under way; and fish spawned in 1949 matched secondyear growth with the $19+5$ year-class by reaching 6.4 inches in length within the 1950 season. In 19+9, the year in which maximum growth rates were attained by bluegills, the total number of these fish was so small that, creel records indicate, few could be caught by anglers, table 3 .

\section{Catch Rate Versus Fishing Pressure}

In observing the catch of largemouth bass at Ridge Lake year after year, it was noticed that the rate of catch dropped off rather rapidly early in the season and that, after about the first 3 weeks, most of the bass taken were caught by a relatively small number of fishermen. This phenomenon was particularly pronounced in 1949 when, following the March draining census, the bass returned to the lake were concentrated in a reduced volume of water. At this time Ridge Lake contained at least $1,0+6$ bass large enough to 
be attractive to fishermen $(1,027$ fish returned after March census, plus unkrown number of unmarked fish, 19 of which were caught during the summer). The total catch and rate of catch for preseason fishing, daily fishing during the first week, and fishing by weeks throughout the rest of the summer fishing season are shown in table 15 , along with man-hours of fishing and calculated number of bass available.

In the June period before the lake was opened to the public (June 1-1t), members of the Illinois Natural History Survey aquatic biology staff fished for bas needed for another phase of the study. Fishing periods (preseason) for one or two men were usually not more than 2 hours in length for any one day. With this very light fishing intensity, 50 bass weighing 52.49 pounds were taken in 17.75 man-hours, at the rate of 2.96 pounds of bass per man-hour, or approximately a pound of bass for each 20 minutes of fishing. On the first day the lake was opened to the public, 67 bass, weighing 78.56 pounds, were taken in 156.0 manhours of fishing, at the rate of 0.5 pound per man-hour. On the second day, only 22 bass, weighing 22.31 pounds, were taken in 121.5 man-hours of fishing, at the rate of 0.18 pound per man-hour. 'The rate of catch was still lower during the next 3 days of fishing that completed the first fishing week. In this week a total of 121 bass weighing $1+0.67$ pounds were taken in 633.5 man-hours of fishing. 'The

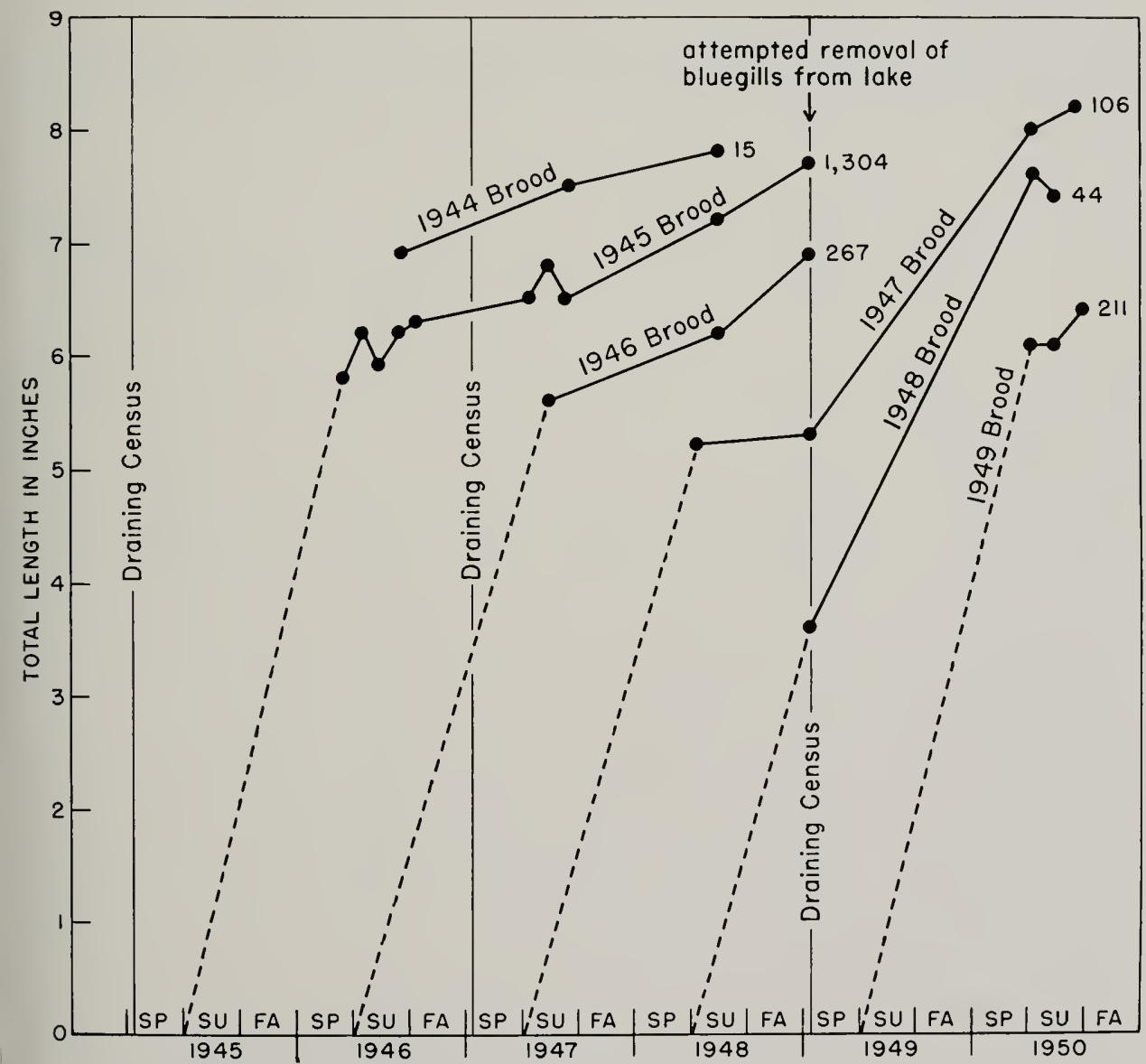

Fig. 14.-Growth rates of bluegills spawned in Ridge Lake, 19+4-19+9; lengths based on measurements of fish in anglers' catches and in draining censuses (sP, spring; sU, summer; FA, fall). 
rate of catch from the third day of fishing to the end of the week was nearly as poor as the average rate for most weekly periods through the remainder of the summer. This poor rate of catch for the last 3 days of the first week followed an accumulation of fishing hours over a 2-day period of about 25 man-hours per acre. Less than 10 per cent of the bass available at the beginning of the public fishing period had been taken by the end of the second day and there was still a bass population of at least 82 fish per acre. When the lake was closed after 11 weeks of fishing, there were still about $t 51$ bass available $(t 1$ per acre); the hook-and-line yield represented 56.9 per cent of the number of fish of 9 inches or more in length that were available when preseason fishing was begun on June 1.

The apparent drop in rate of catch in 1949 from preseason fishing to the rate of even the first day of public fishing, table 15 , suggested that bass were rather quickly influenced by an acceleration of fishing activity. Consequently, fishing data were reassembled to show average rates of catch (by weight) for half-day fishing periods for the first week of fishing during each of the seasons of 19+2, 19tt, 1947 , and 1949-years in which the fish populations were made up entirely or principally of bass. These average rates of catch are shown in table 16 and fig. 15 . The season of 1945 was omitted because muddy water early in the first week,

Table 15.-The 1949 creel at Ridge Lake, with figures arranged to show rapid drop in success of angling associated with intensive fishing. Bass listed as available were at least 9 inches in length. Calculations involving acreage were based on the actual water area of 11 acres.

\begin{tabular}{|c|c|c|c|c|c|c|c|c|}
\hline \multirow[b]{2}{*}{ Period and Date } & \multirow[b]{2}{*}{$\begin{array}{l}\text { MaN- } \\
\text { Hours } \\
\text { OF } \\
\text { FISHING }\end{array}$} & \multicolumn{2}{|c|}{ Avallable Bass } & \multicolumn{5}{|c|}{$\mathrm{CATCH}$} \\
\hline & & Total & Per Acre & Number & $\begin{array}{l}\text { Total } \\
\text { Weight, } \\
\text { Pounds }\end{array}$ & $\begin{array}{l}\text { Hours to } \\
\text { Catch } \\
\text { One Bass }\end{array}$ & $\begin{array}{l}\text { Hours to } \\
\text { Catch } 1 \\
\text { Pound } \\
\text { of Bass }\end{array}$ & $\begin{array}{l}\text { Pounds } \\
\text { of Bass } \\
\text { per } \\
\text { Man- } \\
\text { Hour } \\
\text { of Fish- } \\
\text { ing }\end{array}$ \\
\hline $\begin{array}{l}\text { PRESEASON } 6 / 1-14 \ldots \\
\text { FiRST WEEK OF REgU- } \\
\text { LAR SEason }\end{array}$ & 17.75 & $1,046^{1}$ & 95 & 50 & 52.49 & 0.4 & 0.3 & 2.96 \\
\hline 1st day $6 / 15 \ldots \ldots$ & 156.00 & 996 & 90 & 67 & 78.56 & 2.3 & 2.0 & 0.50 \\
\hline 2 nd day $6 / 16 \ldots \ldots$ & 121.50 & 929 & 84 & 22 & 22.31 & 5.5 & 5.4 & 0.18 \\
\hline 3 rd day $6 / 17$ & 111.25 & 907 & 82 & 8 & 8.87 & 1.3 .9 & 12.5 & 0.08 \\
\hline 4 th day $6 / 18 \ldots$ & 96.50 & 899 & 82 & 10 & 11.44 & 9.6 & 8.4 & 0.12 \\
\hline 5th day $6 / 19 \ldots \ldots$ & 148.25 & 889 & 81 & 14 & 19.49 & 10.6 & 7.6 & 0.13 \\
\hline \multicolumn{9}{|l|}{ Rfglilar Season } \\
\hline Ist week 6/15-19. & 633.50 & 996 & 90 & 121 & 140.67 & 5.2 & 4.5 & 0.22 \\
\hline 2nd week $6 / 22-26 \ldots$ & 627.50 & 875 & 79 & 95 & 82.73 & 6.6 & 7.6 & 0.13 \\
\hline 3rd week $6 / 29-7 / 4$. & 561.00 & 780 & 71 & 77 & 66.77 & 7.3 & 8.4 & 0.12 \\
\hline 4 th week $7 / 6-10 \ldots$ & 357.00 & 703 & 64 & 73 & 54.04 & 4.9 & 6.6 & 0.15 \\
\hline 5th week $7 / 13-17$ & 391.50 & 630 & 57 & 52 & 45.52 & 7.5 & 8.6 & 0.12 \\
\hline 6 th week $7 / 20-24 \ldots$ & 376.25 & 578 & 52 & 25 & 25.50 & 15.0 & 14.8 & 0.07 \\
\hline 7 th week $7 / 27-31 \ldots$ & 317.50 & 553 & 50 & 40 & 24.54 & 7.9 & 12.9 & 0.08 \\
\hline 8 th week $8 / 3-7 \ldots$. & 263.00 & 513 & 47 & 27 & 19.28 & 9.7 & 13.6 & 0.07 \\
\hline 9 th week $8 / 10-14 \ldots$ & 154.00 & 486 & 44 & 17 & 13.85 & 9.1 & 11.1 & 0.09 \\
\hline 10 th week $8 / 17-21 \ldots$ & 139.25 & 469 & 43 & 6 & 4.72 & 23.2 & 29.5 & 0.03 \\
\hline 11 th week $8 / 24-28 \ldots$ & 128.25 & 463 & 42 & 12 & 10.40 & 10.7 & 12.3 & 0.08 \\
\hline \multicolumn{9}{|l|}{ Tosal for presenson and } \\
\hline season.................. & - & - & - & 595 & $5+0.51$ & - & - & - \\
\hline Available bass remaining & - & 451 & 41 & - & - & - & - & - \\
\hline
\end{tabular}

2This number was derived by adding to the 1.027 bass returned to the lake after the 1949 draining census the 19 unmarked bass caught by fishermen in 1949. Three of these unmarked bass were fish spawned in 1948 that had escaped the $1949 \mathrm{draining}$ census: the others were from the 1949 brood. No allowance was made in this calculation for bass of the 1948 brood that had escaped the 1949 draining census and were not caught; for bass of the 1949 brood that had grown to catchable size (about 6 inches or more) and were not caught; or for bass later unaccountably lost, as through natural mortality. 
of the opening morning. In no case was the weight or number of bass taken in the first morning sufficiently great to represent a significant reduction in the total bass population. The catch of highest poundage in relation to total poundage of available bass in the lake was taken during the first is shown in table 17. It is obvious that a sudden drop in catch rate occurred in each of these years regardless of when fishing was begun. (See data for 19tt, when fishing was begun in August.) Years in which few, or no, bluegills were in the lake and the fishing was mostly for bass

Table 17.-Average weekly rate of catch (by weight) of fish at Ridge Lake. In 1942, 1944, 1945,1947 , and 1949, the population of the lake was principally largemouth bass. In 1946, 1948 , and 1950 , large numbers of hluegills as well as bass were available.

\begin{tabular}{|c|c|c|c|c|c|c|c|c|c|c|c|c|c|c|c|}
\hline \multirow[b]{3}{*}{ líshisg Season } & \multicolumn{15}{|c|}{ Rate of Catch in Pounds per Man-Hour of lishing } \\
\hline & \multicolumn{4}{|c|}{ June } & \multicolumn{4}{|c|}{ July } & \multicolumn{4}{|c|}{ August } & \multicolumn{3}{|c|}{ September } \\
\hline & 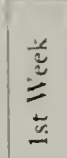 & 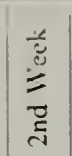 & 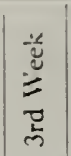 & 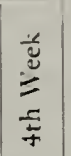 & $\begin{array}{l}\frac{\ddot{\Xi}}{\Xi} \\
\ddot{\sim}\end{array}$ & 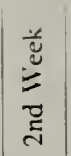 & 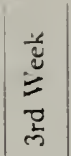 & 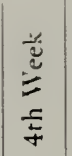 & 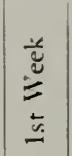 & 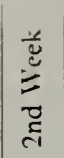 & 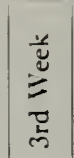 & 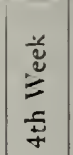 & 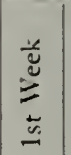 & 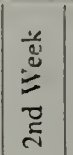 & 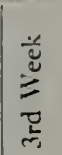 \\
\hline $\begin{array}{l}\text { Bass' } \\
1942\end{array}$ & - & - & 0.13 & 0.06 & 0.04 & 0.02 & 0.06 & 0.10 & 0.02 & 0.01 & 0.01 & 0.01 & - & - & - \\
\hline 1944 & - & - & - & -1 & -1 & - & - & -1 & - & 0.16 & 0.11 & 0.10 & 0.32 & 0.24 & 0.11 \\
\hline 1945. & - & - & 0.37 & 0.33 & 0.15 & 0.10 & 0.07 & 0.18 & 0.32 & 0.12 & 0.11 & 0.07 & 0.29 & - & - \\
\hline 947. & - & 0.18 & 0.10 & 0.07 & 0.07 & 0.10 & 0.05 & 0.03 & 0.18 & 0.14 & +0.11 & 0.22 & 0.24 & - & - \\
\hline $19+9$ & - & (0. 22 & 0.13 & 0.12 & 0.15 & 0.12 & 0.07 & 0.08 & 0.07 & 0.09 & 0.03 & 0.08 & - & - & - \\
\hline BASS AND BI.UEGILLS ${ }^{2}$ & 0) 32 & 20.33 & 0.24 & 0.20 & 0.18 & 0.21 & 0.19 & 0.12 & 0.17 & 0.17 & 0.20 & 0.18 & 0.23 & - & - \\
\hline & - & 0.41 & 0.25 & 0.26 & 0.16 & 0.21 & 0.23 & 0.15 & 0.24 & 0.23 & 0.21 & 0.19 & 0.16 & - & - \\
\hline 1950. & - & - & 0.13 & 0.14 & 0.13 & 0.08 & 0.09 & 0.07 & 0.09 & 0.10 & 0.25 & 0.15 & - & - & 一 \\
\hline
\end{tabular}

1 The grand average for the years in which fishing was principally for largemouth bass was 0.13 pound per man-hour of fishing.

3 The krand average for the years in which large numbers of bluegills as well as bass were available was 0.19 pound per man-hour of fishing.

morning of the 1949 fishing season; it amounted to approximately 6.3 per cent of the available poundage. The catch of largest number in relation to the total number of available bass in the lake was taken in the first morning of 1947; it amounted to about +.6 per cent of the available population. 'The fact that the catch rate of hass dropped in all years within a few hours after the lake was opened to public fishing, and before more than a small proportion of the available bass population had been caught, suggests either that the more aggressive fish were hooked early on the first day or that the fish lucky enough to avoid being hooked during the first few hours became wary of noisy boats and of baits attached to lines.

'That the rate of catch (by weight) of hass dropped to a low level within the first few weeks of fishing in each of the years in which public fishing was allowed
$(19+2,19+4,19+5,19+7$, and 1949) are shown in the upper part of table 17 ; years of considerable fishing for both bass and bluegills are shown in the lower part.

Interesting points suggested by the upper division of table 17 are that in most years the poorest weeks of bass fishing occurred during middle or late July or middle or late August. In 1945, 1947, and 19+9, an increase in catch rate (by weight) appeared in either the first or second week in August. In all years shown in the upper part of table 17 except 19+2, a rise in catch rate was shown for either the last week in August or the first week in September. This late-season rise probably was associated with a cooling of the lake, resulting from lower air temperatures at night. No explanation is suggested for the striking fluctuations in weekly catch rates that appeared in some years during July and August. 
The highest average weekly rate of catch (by weight) for bass was recorded for the first week of the $19+5$ fishing season ( 0.37 pound per man-hour), table 17. This catch rate was affected by muddy water during a part of the week, by a low total of fishing hours for the entire week, and by a phenomenal catch of bass made by two expert fishermen who had the lake to themselves during one fishing period. The average rate of catch for the second week of the $19+5$ season ( 0.33 pound per man-hour) was nearly as high as for the first; it was higher than the average for the first week of each of the other years in which all or nearly all fishing was for bass. Ricker (19+2:228) recorded the rate of catch of bass fishermen at Shoe Lake, Indiana, for the second half of June as being +.9 pounds per 10 pole-hours $(0 .+9$ pound per man-hour); this period was followed by a number of 2-week periods when fishing was much poorer ( 0.10 to 0.23 pound per man-hour). The average rate of catch for the entire summer period was 2.6 pounds per 10 pole-hours $(0.26$ pound per man-hour), which is somewhat higher than the rate at Ridge Lake for any single year or for the grand average rate, table 17.

At Ridge Lake, bluegills were more easily caught than were bass and were less seasonal in their biting. 'Thus, in years when sizable populations of bluegills as well as bass were available to fishermen, the average weekly catch rates (pounds per man-hour) were higher and less subject to severe fluctuations than in years when only bass were available.

As described in the section on the creel census, fishing was done only from the seven boats owned by the Natural History Survey, and the public was not allowed to fish from the lake bank or piers. The boats were assigned to fishermen making advance reservations; a fisherman could use a boat by himself or take one, two, or three other persons with him. Boats were not supplied with anchors, and if a fisherman wished to use an anchor he was expected to provide it.

All occupants of boats were recorded as fishing all of the time they were on the lake. For example, if three men were using a boat, fig. 3 , one man manipulating the oars and the other two actually fishing, they were recorded as though all three were fishing all of the time they were on the lake. 'Two men in a boat were recorded as two fishermen, even though the two alternated between rowing and fishing; one man by himself in a boat was recorded as one fisherman fishing the entire time he was on the water even though he spent about half of his actual time on the lake in keeping his boat in position for fly or bait casting.

It has been estimated that the rates of catch in terms of pounds of fish per manhour of actual fishing time might be 50 to 100 per cent higher than the rates of catch given in tables 15,16 , and 17 .

\section{Factors Affecting Yields of Bass}

In table 18, an attempt has been made to show the catch of bass in relation to number and weight of bass available, man-hours of fishing, and available forage in the form of small bass and bluegills. Methods of estimating numbers and weights of bass were the same as are described in the section "Spawning Success and Population Density." The fishing pressures in man-hours per acre include fishing effort directed toward bluegills as well as bass, as the two cannot be separated.

Bass yields varied from 10 to $5+$ fish per acre and from 10.9 to +9.2 pounds per acre (when the $19+9$ yield is figured on the basis of the $19+9$ lake area) and represented 9 to $6+$ per cent of the number available and $2+$ to 69 per cent of the weight available, table 18 . The highest percentages of catch of available bass occurred in years following the March drainings $(19+5,19+7$, and 1949), when, as a result of draining and culling operations, populations of small bluegills, crayfish, and other bass foods were much reduced. In $19+5$ the population of small bass was high, in $19+7$ moderate, and in 1949 low, as a result of the success of the bass spawn in those years. The number of fish designated as a high population for bass was much smaller than the number listed as a high for bluegills. While the yield of bass in numbers and pounds per acre was in some measure dependent on the man-hours of fishing and the available bass per acre, the factor that seemed to have the greatest 
influence on the total exploitation for a given season was the relative abundance of natural food. In no year in which natural food was "nomally" abundant (had not been reduced through artificial means) did the catch of bass exceed 40 per cent of the available crop, either in numbers or pounds, even under a fishing pressure that in one season averaged more than 300 man-hours per acre. It is improbable that greater fishing pressure would have had much effect upon yield under "normal"

\section{Unaccountable Mortality and Length of Life}

One of the more difficult problems in studying a population of fish is to determine the final disposition of individuals in that population. Marked fish that are caught by co-operating anglers and most of those that are accidentally killed in draining operations are accountable; so are fish that die from accidents or from hooking injuries and are found floating

Table 18.-Number and weight of available largemouth bass per acre, catch of bass per acre, fishing pressure, and abundance of bass forage in the form of small fish, Ridge Lake. 1942-1950. Calculations involving acreage were based on a water area of 18 acres except where stated otherwise.

\begin{tabular}{|c|c|c|c|c|c|c|c|c|c|}
\hline \multirow[b]{2}{*}{$\begin{array}{l}\text { Fishisg } \\
\text { SEason }\end{array}$} & \multicolumn{2}{|c|}{$\begin{array}{c}\text { AVAllable } \\
\text { Bass per ACre }\end{array}$} & \multirow[b]{2}{*}{$\begin{array}{c}\text { Fishisg } \\
\text { Pressure, } \\
\text { MaN-Hours } \\
\text { PER ACre }\end{array}$} & \multicolumn{2}{|c|}{$\begin{array}{c}\text { Avallable Bass } \\
\text { Forage }\end{array}$} & \multicolumn{4}{|c|}{ CATCH OF BASS PER ACRE. } \\
\hline & Number & $\begin{array}{l}\text { Weight, } \\
\text { Pounds }\end{array}$ & & $\begin{array}{l}\text { Small } \\
\text { Bass }\end{array}$ & $\begin{array}{c}\text { Small } \\
\text { Bluegills }\end{array}$ & Number & $\begin{array}{l}\text { Weight, } \\
\text { Pounds }\end{array}$ & $\begin{array}{c}\text { Per } \\
\text { Cent } \\
\text { of } \\
\text { Avail- } \\
\text { able } \\
\text { Number }\end{array}$ & $\begin{array}{l}\text { Per } \\
\text { Cent } \\
\text { of } \\
\text { Avail- } \\
\text { able } \\
\text { weight }\end{array}$ \\
\hline $\begin{array}{l}1942 \ldots \\
1944^{3} \ldots \\
1945 \ldots \\
1946 \ldots \\
1947 \ldots \\
1948 \ldots \\
1949 \ldots \\
19495 \ldots \\
1950 \ldots\end{array}$ & $\begin{array}{r}290^{1} \\
90 \\
36 \\
87 \\
22 \\
149 \\
57 \\
93 \\
73\end{array}$ & $\begin{array}{l}63 \cdot 3^{2} \\
54.6^{2} \\
28.7^{4} \\
46.1^{2} \\
27.0^{4} \\
76.0^{2} \\
44.7^{4} \\
73.2^{4} \\
62.6^{2}\end{array}$ & $\begin{array}{r}212 \\
90 \\
105 \\
168 \\
155 \\
320 \\
220 \\
361 \\
224\end{array}$ & $\begin{array}{l}\text { Low } \\
\text { Very low } \\
\text { High } \\
\text { Very low } \\
\text { Moderate } \\
\text { None } \\
\text { Low } \\
\text { Low } \\
\text { Very low }\end{array}$ & $\begin{array}{l}\text { None } \\
\text { Moderate } \\
\text { Low } \\
\text { Very high } \\
\text { Low } \\
\text { Very high } \\
\text { Very low } \\
\text { Very low } \\
\text { Very high }\end{array}$ & $\begin{array}{l}27 \\
26 \\
23 \\
20 \\
10 \\
36 \\
33 \\
54 \\
29\end{array}$ & $\begin{array}{l}15.1 \\
15.0 \\
19.8 \\
14.6 \\
10.9 \\
25.6 \\
30.0 \\
49.2 \\
18.3\end{array}$ & $\begin{array}{r}9 \\
29 \\
64 \\
23 \\
45 \\
24 \\
58 \\
58 \\
40\end{array}$ & $\begin{array}{l}24 \\
27 \\
69 \\
32 \\
40 \\
34 \\
67 \\
67 \\
29\end{array}$ \\
\hline
\end{tabular}

${ }^{1}$ Only about 24 legal-sized bass per acre. Fishermen took only legal-sized fish; Natural History Survey catches included fish of less than legal size.

2 Weight estimate based on actual catch plus weight of catchable bass (about 6 inches or more in length) in census of spring following. The estimate is too high, because no adjustment was made for compensatory weight increase as a result of cropping.

Ridge Lake was not opened to public fsshing in 1943; public fishing in 1944 was begun in August.

Weight estimate based on weight of bass actually put back into lake following census. Estimate is too low (except posibly that for 1949) because no allowance was made for weight gains between the time bass were returned to the lake and the time they were caught. In 1949, bass may have decreased in weight because they were crowded. 3 Figured on the basis of a lake area of 11 acres, the actual area for the fishing season.

food conditions. But in 1945, for example, when food conditions were probably considerably below "normal," a fishing pressure of 105 man-hours per acre resulted in a total exploitation of 64 per cent of the number and 69 per cent of the weight of available bass. Thus, the culling technique that was associated with the biennial draining censuses at Ridge Lake not only allowed the fish replaced in the lake to grow rapidly to sizes satisfactory to anglers, but it also increased the rate of catch and the rield in numbers and pounds. on the water. However, in the Ridge Lake study, many marked fish simply disappeared from the lake. The disappearance of the fish may be attributed to one of the following causes: (1) natural mortality of fish that were unobserved after they had risen to the surface of the water or were torn apart before decay had pro. gressed sufficiently to cause them to float, (2) escape of fish from the lake by way of the surface spillway in time of high water, (3) injury to fish during draining and censusing operations, followed some time later by death and failure of these 
fish to float, $(t)$ loss of fish that became stranded or buried in the bottom mud at the time of lake draining and were not retrieved, (5) loss of fish through poaching during periods when the lake was closed to public fishing.

As described previously, the first bass placed in Ridge Lake were marked by recorded as belonging to their respective groups. Unmarked fish were given the fin mark of the census being made.

Marked fish caught by fishermen in the summer fishing period were recorded by the biologist in charge of the creel census. The lake was scouted almost daily in this period for dead fish and, when these were

Table 19.- Rates of exploitation and unaccountable losses of marked largemouth bass, Ridge Lake, 1941-1951.

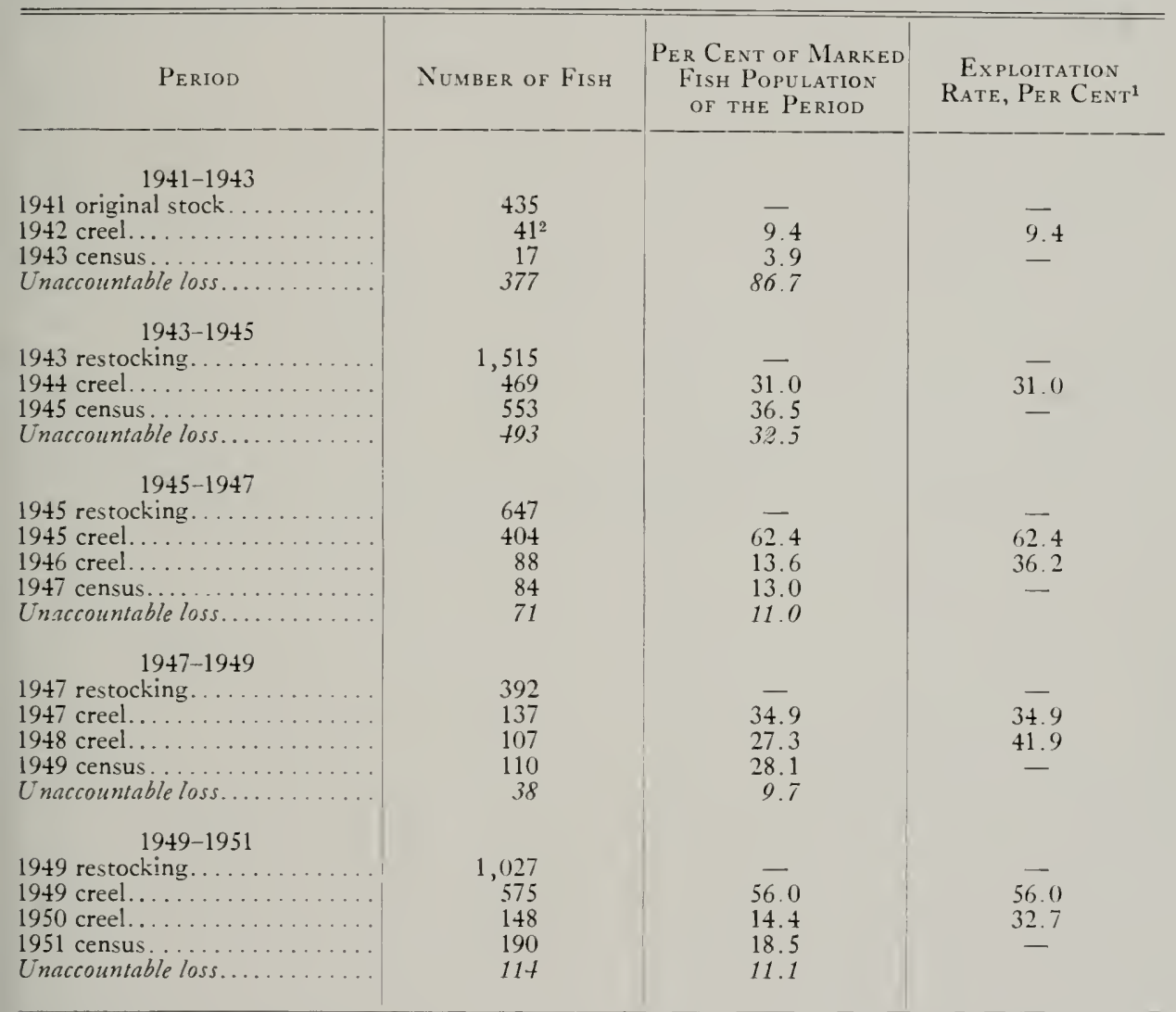

1 Exploitation rate is based on the theoretical number of marked fish present in the lake at the beginning of the fishing season.

2 Includes one fish taken in 1941.

removal of one fin (left pectoral of bass from Lake Chautauqua, right pectoral of bass from Craborchard Lake, and dorsal of bass from Lake Glendale). Bass spawned in the lake were marked by removal of fins as designated in table 20. Before bass were replaced in the lake following each draining census, those that already carried a fin mark designating original stock or a previous census were found, their lengths and marks were recorded. Very few dead fish were seen floating on the lake during the fishing periods of the years 19+1-1951. Of the small number of dead fish found, most appeared to have died following injuries that resulted from being hooked. A few had died on lost stringers. Data on fish that had died from fishing injuries or on lost stringers and were later found were 


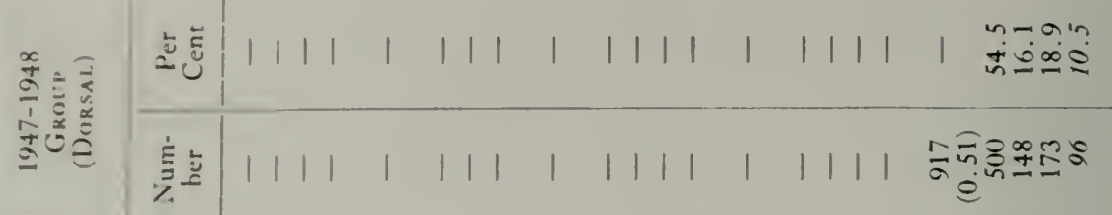

产产

光过芯

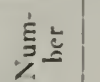

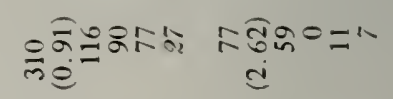

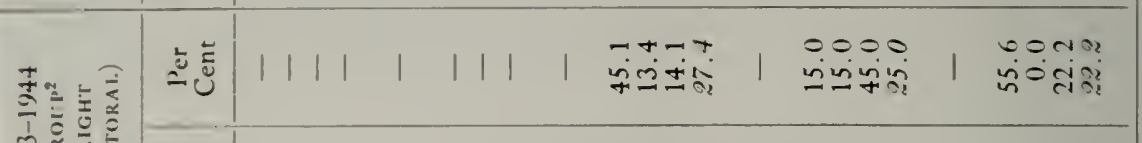

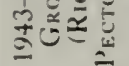

$\stackrel{\Sigma}{\check{z}}$

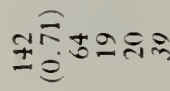

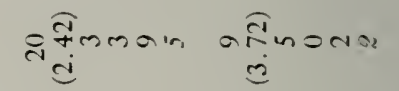

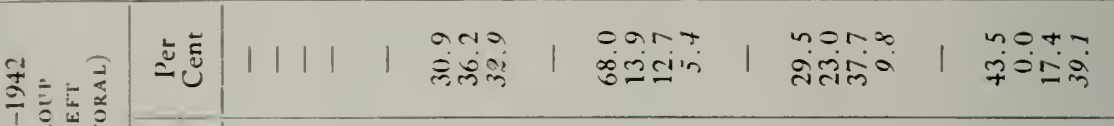
可产芯

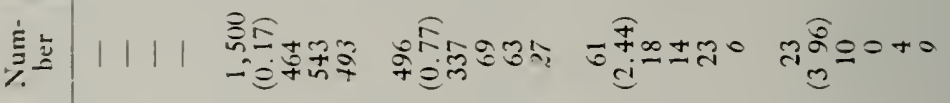

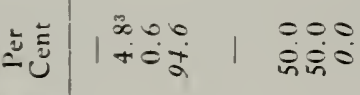

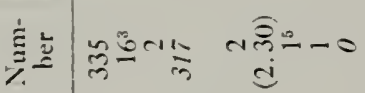

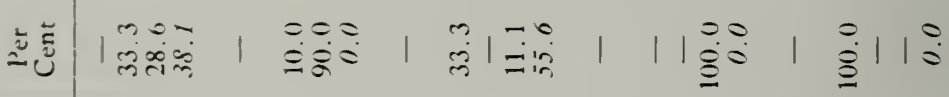

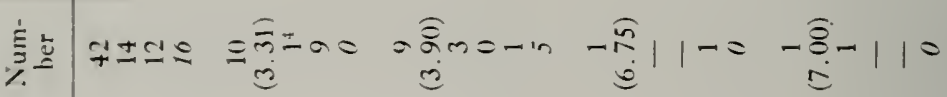
F 2 荘

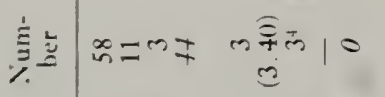


added to the creel record. Our biennial inventories of fish allowed an evaluation of most of the losses that occurred.

When the marked fish taken by anglers were added to those found dead and those counted in the succeeding census and the resulting sum was subtracted from the number of marked fish returned to the lake following the preceding census, there was always a shortage - an unaccountable loss of bass that had taken place during the 2-year period. 'This loss was the result of natural mortality or of the other four undetected decimating factors listed above. The bass that unaccountably disappeared between censuses were simply designated as unaccountable losses.

For each of the 5 biennial periods beginning with $19+1$ and ending with the draining census of 1951, tables 19 and 20 show the number of marked bass placed in the lake, the number taken by angling in the two fishing seasons, and the number recaptured at the time of the next census. Table 20 lists the original stock separated into groups based on origin and other fish separated into broods to show differences in unaccountable losses in various groups during various periods.

Information on the capture, holding methods, and transportation of the bass introduced into Ridge Lake in $19+1$ is of particular interest because the unaccountable losses among these bass amounted to 86.7 per cent within the first 2 years, table 19. Table 20 shows the unaccountable losses among the groups of fish obtained from the three sources: Craborchard, Chautauqua, and Glendale lakes.

The Craborchard Lake fish (marked left pectoral) were caught in wing nets on April 27, 28, and 29, 19+1; those caught on the first 2 days were held in nets with the funnels closed until the third day, when all of the nets were raised. The fish were placed in a tank truck equipped with an air compressor and transported to Ridge Lake, a road distance of about 150 miles. The weather during the road trip was unseasonably warm. All fish used in stocking the lake were apparently in good condition on arrival, but the unaccountable loss in this group as revealed by the March, 19+3, census was 75.8 per cent, table 20 .

The Lake Chautauqua fish (marked right pectoral), in which the unaccountable loss as of March, 19+3, was only 38.1 per cent, were captured in wing nets in March and April, 19+1, and transported to the Department of Conservation's fisheries station at Havana, about 5 miles from the lake in which they were captured. There they were placed in tanks supplied with cold, well-aerated water and held, most of them for several weeks. Fish that were injured in netting probably showed the effects of these injuries during the holding period and were removed from the tanks. On May 1, bass remaining in the tanks were transported to Ridge Lake; the trip by road was begun early in the morning and was completed before the warm part of the day. The distance by road is $1+5$ miles.

The greatest losses occurred among the fish from Lake Glendale (marked dorsal), which were seined on June 17, held overnight in a holding net staked out in Lake Glendale, and transported to Ridge Lake on June 18. The weather was very warm during the trip of about 180 miles. Although all of the Lake Glendale fish placed in Ridge Lake appeared to be in fair shape (fish were thrown out that had died or that showed signs of having become sick on the road), the unaccountable loss among this group of fish was 317 of 335 or 94.6 per cent by March, $19+3$.

The high loss of fish in the groups of bass moved to Ridge Lake from Craborchard and Glendale lakes suggests the importance of low temperatures and the careful handling of fish being transported from one water to another. None of the transported bass released in Ridge Lake appeared to be sick at the time of release. Yet many of them had evidently sustained injury sufficient to cause death. The unaccountable loss was considerably higher among the bass with which Ridge Lake was stocked in $19+1$ than among bass spawned in the lake and subjected to no handling except that during biennial draining censuses. Bass are more often transported as fingerlings than as larger fish, and fingerlings may or may not be more subject to injury. The bass transported from Lake Glendale were 5.0 to 7.0 inches in length; those from Craborchard 6.5 to 11.5 inches; and those from Chautauqua 8.5 to 17.0 inches, table 2 . 
The program of marking and censusing has made it possible to trace the reduction in numbers of each marked group throughout the period of the experiment. 'I'he +35 tish of the original stock had been reduced to 17 by the end of the first 2-year period, table 20. As 2 of these fish were killed in the draining operation, only 15 were anailable for restocking the lake after the census.

All 15 could be accounted for at the end of the next 2-year period (19+31945): + had been caught by fishermen and 1 was found after it had died, evidently as a result of a hooking injury; 10 were recovered in the $19+5$ census and, of these, 1 was injured in the census and 9 were replaced in the lake after the census. These 9 were fish that had been brought from Lake Chautauqua. At the beginning of the $19+5-1947$ period they averaged 3.9 pounds each and were probably 7 to 10 years old; during the period 3 were caught, and only 1 was recovered at the time of the 1947 census. Thus, the unaccountable loss in this period was 5 (55.6 per cent) in contrast to no unaccountable loss in the preceding 2-year period. The fish recovered in the 1947 census weighed 6.75 pounds when returned to the lake in $19+7$. It was recaptured ( 7.0 pounds) at the time of the 1949 census and was caught by a fisherman ( 6.5 pounds) in July of $19+9$. Scales collected at the time of capture indicated that this bass was 10 years of age.

Of the 1,500 marked bass of the 1941 and $19+2$ broods or year-classes that were returned to the lake following the 1943 census, $+6+$ were taken in the 1944 creel and $5+3$ were retaken in the $19+5$ draining census, leaving 493 to be accounted for, or a loss of 32.9 per cent. In the next 2-year period (19+5-19+7), 496 were returned to the lake, and of these 337 were caught in 1945 and 69 in 1946. Sixtythree were taken in the 1947 census, leaving 27 unaccounted for, or a loss of only $5 .+$ per cent.

During the 19+7-1949 period, the num. her of bass of the $19+1$ and 1942 broods was reduced by all causes from 61 to 23 ; the unaccountable loss was 6 fish, or 9.8 per cent of the number returned to the lake in $19+7$. Only $t$ of the 23 bass returned to the lake following the 1949 census were recaptured in the 1951 census. 'len of these 23 fish were caught by fishermen in 1949 , none in 1950 ; 9 were unaccountable losses.

The 1941-1942 group is of particular interest because of its changes in unaccountable losses from $19+3$ to 1951 . In 1945 , the losses in this group for the 19+3-19+5 period were figured as 32.9 per cent. In March, 19+3, these bass averaged 0.17 pound each; by $19+5$, they averaged 0.77 pound; and, by 1947, 2.44 pounds. In the 1945-19+7 and the 19471949 periods the unaccountable losses were 5.4 and 9.8 per cent, respectively. In the 1949-1951 period, when the bass of this group averaged between about 4 and 5 pounds each, the unaccountable losses were 39.1 per cent. These fish were approaching an age of 10 years and it seems reasonable to believe that natural mortality may have been responsible for much of the relatively high unaccountable loss in the 1949-1951 period.

When the reduction in numbers of bass in the 1941-1942 year-classes that resulted from fishing and all other causes over the period 19+3-1951 is compared with a hypothetical 50 per cent annual reduction in numbers, the regressions are found to be quite similar, table 21 .

In the Ridge Lake study, the 19411942 year-classes constituted the only group of fish large enough and old enough to give satisfactory figures covering the approximate life span of bass. 'The less comprehensive data from 1945-1946 and 1947-1948 groups failed to follow the reduction pattern of the 1941-1942 group, and it seems likely that the similarity of the regression pattern of the last-named group to a 50 per cent annual reduction pattern may be coincidental.

\section{Exploitation Rates}

The rates at which the populations of marked bass were exploited by anglers are shown in table 19. As it was impossible to assign instantaneous times of occurrence to the unaccountable losses that were brought to light when the lake was drained at the end of each 2-year period, the exploitation rate shown in table 19 for any one fishing season is a simple percentage derived from the number of bass 
Table 21.-Observed reduction in numbers of marked largemouth bass of the 1941-1942 group in Ridge Lake, 1943-1951, and a hypothetical 50 per cent annual reduction in numbers.

\begin{tabular}{|c|c|c|}
\hline IEAR & $\begin{array}{c}\text { ObSERVED } \\
\text { ReduCtion } \\
\text { IN Numbers } \\
\text { OF THE } \\
1941-1942 \\
\text { Group OF BASS }\end{array}$ & $\begin{array}{c}\text { Fifty } \\
\text { Per Cent } \\
\text { AnNual } \\
\text { Reduction } \\
\text { in Numbers }\end{array}$ \\
\hline $\begin{array}{l}1943 \ldots \\
1945 \ldots \\
1947 \ldots \\
1949 \ldots \\
1951 \ldots\end{array}$ & $\begin{array}{r}1,500 \\
496 \\
61 \\
23 \\
4\end{array}$ & $\begin{array}{r}1,500 \\
375 \\
94 \\
24 \\
6\end{array}$ \\
\hline
\end{tabular}

caught by fishermen and the number of bass that should have been in the lake during the fishing season if there had been no unaccountable losses. As such losses were undoubtedly occurring throughout each fishing season, the actual exploitation rates must have been higher than figures in the table indicate. This is true particularly of the $19+1-19+3$ period when the unaccountable loss of bass originally placed in the lake was 86.7 per cent. If all of this loss had occurred in 19+1, the exploitation rate in $19+2$ would have been nearly 71 per cent. In any case, the lower the unaccountable loss for a 2-year period, the nearer the calculated exploitation percentage approaches the true figure. It is probable that in the last three biennial periods, in which the unaccountable losses ranged from 9.7 to 11.1 per cent, the calculated exploitation rates are only slightly below the true rates.

The calculated exploitation rates for marked largemouth bass at Ridge Lake were, for all but a single year, higher than the rate of 20 per cent reported by Ricker $(19+2: 248)$ for Shoe Lake, Indiana, or the rate of 18.5 per cent reported by Eschmeyer (19+2:109) for Norris Reservoir. Exploitation rates reported by Ricker and Eschmeyer were based upon recaptures of tagged fish; like the rates for Ridge Lake fish, they were based upon numbers of fish, rather than weights. Exploitation rates based upon weights of bass are usually lower than those based upon numbers, because small bass are more readily caught than are larger ones.
It is significant that the two highest exploitation rates at Ridge Lake were for years in which food was scarce as a result of draining operations, table 19.

\section{Efficiency of Baits}

The natural baits (most of them alive) used at Ridge Lake included minnows, crayfish, hellgrammites, earthworms, grasshoppers, catalpa worms, worm and spinner combinations, and canned shrimp. Minnows and crayfish were by far the most efficient in catching large bass (Durham \& Bennett 1949:11;1951:6). For the fishing seasons of the period 19+2-19+9, minnows had an average catch rate of one desirable bass (10 inches or longer) for t.0 man-hours of fishing, and crayfish a rate of one desirable bass for 5.3 manhours (Durham \& Bennett 1951:6). The average catch rates for the other natural baits varied from one bass of desirable size for 10.5 man-hours to one for 48.3 man-hours of fishing. Earthworms were used for bait a larger number of manhours than were any of the other natural baits (2,823 man-hours); this bait caught $55 .+$ per cent of the bass of less than 10 inches in length that were taken, but only 16.5 per cent of the bass of desirable sizes.

Individual kinds of plugs, spoons, and spinners, used with a casting rod and reel and fished on eight or more trips, caught desirable-sized bass at rates varying between one fish per 1.9 hours and one per 5.7 hours (Durham \& Bennett 1951:6). These baits were used during 1,607 manhours of fishing and caught 586 bass of desirable sizes and 137 smaller ones. More bass were caught on underwater plugs than on floaters, particularly after the month of June, when the surface water of the lake was very warm.

Fly-rod lures accounted for 615 large bass and +69 small ones in 1,892 manhours of fishing (Durham \& Bennett 1951:7). More fishermen used corkbodied popping bugs and minnows than any other type of bait, and these baits were very efficient in catching bass.

In table 22, the efficiency of natural baits can be compared with that of castingrod plugs and fly-rod lures in catching bass. Many fishermen using earthworms fished primarily for bluegills, but it seems 
Table 22.-Fiffiency of natural baits (mostly alive) and of artificial baits for casting rods and $f y$ rods used for catching largemouth bass at Ridge Lake, 1942-1949 (from Durham \& Bennett 1951: 7 ). Desirable bass are those of 10 inches or longer.

\begin{tabular}{|c|c|c|c|c|c|c|c|c|}
\hline \multirow{2}{*}{ Trie of batt } & \multirow{2}{*}{$\begin{array}{c}\text { NuMBER } \\
\text { OF } \\
\text { TRIPS }\end{array}$} & \multirow{2}{*}{$\begin{array}{l}\text { MaN- } \\
\text { Hours } \\
\text { OF } \\
\text { JishING }\end{array}$} & \multicolumn{2}{|c|}{$\begin{array}{l}\text { BASS OF } 10 \\
\text { INCHES OR } \\
\text { LONGER }\end{array}$} & \multirow{2}{*}{$\begin{array}{c}\text { Bass of } \\
\text { Less } \\
\text { Than } \\
10 \\
\text { INches, } \\
\text { Number }\end{array}$} & \multirow{2}{*}{$\begin{array}{c}\text { RaTIO OF } \\
\text { DESIRABLE } \\
\text { TO } \\
\text { S.MALI.ER } \\
\text { BASS }\end{array}$} & \multicolumn{2}{|c|}{ Total Catch } \\
\hline & & & Number & $\begin{array}{l}\text { Man- } \\
\text { Hours } \\
\text { per } \\
\text { Fish }\end{array}$ & & & Number & $\begin{array}{l}\text { Bass } \\
\text { per } \\
\text { Mlan- } \\
\text { Hour }\end{array}$ \\
\hline $\begin{array}{l}\text { Live and other nat- } \\
\text { ural baits....... } \\
\text { Casting-rod lures.. } \\
\text { Fly-rod lures....... } \\
\text { Total........... }\end{array}$ & $\begin{array}{r}1,847 \\
744 \\
800 \\
3,391\end{array}$ & $\begin{array}{r}6,252 \\
2,188 \\
2,150 \\
10,590\end{array}$ & $\begin{array}{r}830 \\
768 \\
672 \\
2,270\end{array}$ & $\begin{array}{l}7.53 \\
2.85 \\
3.20 \\
-\end{array}$ & $\begin{array}{r}1,383 \\
211 \\
626 \\
2,220\end{array}$ & $\begin{array}{l}1 \text { to } 1.67 \\
1 \text { to } 0.27 \\
1 \text { to } 0.93 \\
-\end{array}$ & $\begin{array}{r}2,213 \\
979 \\
1,298 \\
4,490\end{array}$ & $\begin{array}{l}0.35 \\
0.45 \\
0.60 \\
-\end{array}$ \\
\hline
\end{tabular}

obvious that fishermen had more confidence in live baits, for bass as well as bluegills, than in artificials; they used live baits during nearly three times as many hours of fishing as either casting-rod plugs or Hy-rod lures. The catch rate (hass per man-hour) for each of the two groups of artificial baits was superior to that of the natural-bait group, table 22. The figures in this table, however, may not be a fair representation of the relative efficiency of the baits, because fishermen had a tendency to try artificial baits at the start of each fishing period, then switch to natural baits if the artificials were ineffective, and, if the natural baits also failed to catch fish, still continue to use them. "Thus, it was possible to build up many "low catch" hours to be assigned to fishing with natural baits.

In laboratory experiments, Brown (1937:53-t) discovered that the largemouth bass is able to distinguish colors quite readily, particularly red. His experiment suggests that the color-distinguishing ability of the bass eye is comparable to that of the normal human eye when the latter is covered with a yellow filter. The following quotations are from Brown $(1937: 53-t)$ :

"Freshly collected bass which have been in the laboratory no more than two days, and fed Daphnia during that time, are most attracted by red, then in order of decreasing attraction of the colors used came yellow, white, green, blue and black.

"Red appears to be the outstanding color, as such, in the responses of the bass.
This color is easily and readily selected from everything else, with the exception of violet."

Colors seemed to be of some importance in stimulating the Ridge Lake bass to strike. While our records of the colors of casting-rod plugs and fly-rod lures used by fishermen at Ridge Lake are incomplete, the available data indicate that, in plugs, red and white combinations attracted more fish than any other colors or combinations; silver alone and black alone in that order were next in apparent effectiveness. For fly-rod lures, yellow was the most effective color; a total of 285 bass were caught on fly-rod lures listed as yellow or as combinations of yellow with other colors. White or combinations of white with other colors were next in effectiveness, followed by combinations of various shades of brown.

After studying the catch records of individual fishermen who fished the lake often, it was apparent that skill played an important role in bass fishing. For example, in $19+9$ the average rate of catch of bass for all fishermen was 1 pound in 7.1 hours. One man who fished the lake $1+$ times throughout that summer had a catch rate for bass of 1 pound in 1.76 hours, while another who fished the lake 20 times had a catch rate of 1 pound in 11.1 hours. Both were experienced enthusiastic bass fishermen, both used artificial haits and knew the lake well. Yet one man was more than six times as efficient as the other in catching fish.

During the first few days of public fishing in each year at Ridge Lake, the 
bass that are not caught have an opportunity to become familiar with the more common methods used by fishermen in presenting artificial baits. Observations on the fishing techniques employed by the most successful bass fishermen suggest that these men vary their techniques much more than do those fishermen who are less successful.

\section{Cost of Fishing}

In 19+9, a study was made of the amount of money spent for contingent travel, meals, equipment, and licenses by the fishermen who made reservations to fish at Ridge Lake (Bennett \& Durham 1951). It was calculated that the average cost of a fishing trip was $\$ 1.22$ per hour (Bennett \& Durham 1951:13). When the average hourly cost was assigned to the average catch in pounds of bass per hour, the amount of money spent to catch a pound of bass was calculated to be $\$ 8.66$. The bass population of the lake was assumed to be $1,0+6$ fish at the beginning of the 1949 fishing season, table 15. Fishermen spent about 3,949 hours angling for these bass and caught 594 , weighing $5+0.5$ pounds (Bennett \& Durham 1951:9). The rate of catch was 0.14 pound per hour or 1 pound per 7.1 hours.

The average bass fisherman probably spends somewhat more than $\$ 8.66$ per pound for the bass that he brings to creel, because usually he rents a boat (no boat rental charge was made at Ridge Lake); the population of bass at Ridge Lake was unusually high in the year the study was made; and this population, which had developed in 18 acres of water, was concentrated in 11 acres of water.

\section{Discussion}

Within the period of study covered by this publication, spring of $19+1$ through the bass spawning season of 1951, more than 11,000 largemouth bass were permanently removed from Ridge Lake, table 3. These fish were offspring of 435 bass introduced into the lake during the spring of $19+1$, table 2. Of these 435 , only 100 were sexually mature in $19+1$; the others were yearlings. There is evidence that most of the bass making up the eriginal stock died very soon after being introduced, table 19. Of the bass removed from Ridge Lake previous to the angling season of $1951,3,7+3$ were taken by anglers and the rest removed in draining censuses as excess small fish, table 3 .

Bluegills were placed in Ridge Lake in $194+$ (129 adult fish) and, from the summer of 1945 through March, 1951, approximately 155,000 of these fish were removed from the lake ( 9,073 by anglers), table 3 , indicating that bluegills are more prolific than are bass.

In the $S$ years of the study period that the lake was open to the public for fishing, the annual bass yield varied between a low of 10.9 pounds per acre and a high of 30.0 pounds per acre, table 8 . These figures are based on a lake area of 18 acres. A still higher figure, 49.2 pounds per acre, is derived for 1949 when the reduced lake area for that year, 11 acres, is used as a basis for calculation, table 18 . In spite of the fact that Ridge Lake is located in soils of moderately low fertility and cannot be expected to compare in productivity with impoundments in better soils, the yields of bass were 2 to 10 times the yields of bass in unmanaged Illinois waters for which figures are available. A basic requirement for a high yield of bass is a high population of this species; however, because of the behavior idiosyncrasies of the species, a high yield may not be a certainty even when a high population is present.

The history of largemouth bass in new, unmanaged impoundments containing more than one species of fish is one of a high population at first, which gradually becomes smaller, so that, within a span of years equal to that covered by this study, the population may drop to a very low level. At Ridge Lake the population level of bass appeared to increase somewhat, and the highest yields from angling were recorded in $194 S$ and $19+9$, near the end of the 10 -year period reported here.

When the lake contained only largemouth bass (19+1-19+4), a satisfactory spawn was produced in each year except 1944. After bluegills were introduced, the years of good bass spawn production were those in which the lake was drained and bluegills and other small fish were 
removed prior to the bass spawning season. In some of the years in which many small bluegills were present, only a very small number of bass try could be found; in others, none at all. 'The high sustained yield of bass at Ridge Lake was a result of successful natural reproduction and satisfactory survival of young bass every other year. 'There was little relationship between the number of spawners and the number of fry they produced, table 10 ; there was an inverse relationship between the number of hass fry and the number of small bluegills in the lake at spawning time.

The key to successful management of largemouth bass in Ridge Lake has proved to be the control of the numerical size or the populations of fishes other than bass that inhabit the water. If bass in other waters are similarly influenced by populations of other fishes, it is doubtful if closed seasons, length limits, and creel limits, which have been relied upon for many years to protect and enhance bass populations, have been of any value. The minimum length limit of 10 inches, the creel limit of 10 , and a closed season of March 1 to June 15 were first introduced into Illinois in 1923. There is no evidence that these fishing regulations have had any influence on bass fishing in the state.

Ridge Lake was not opened to public fishing in any year until after the bass spawn had been observed or the adults were spent (in a year in which no spawn was seen), so that bass that were spawning in the lake always were protected from human interference. In years when many small fish were present in Ridge Lake and bass spawn production was very low $(19+4,19+6,19+8$, and 1950, table 10), the opening of the lake to intensive angling during the bass spawning season could have had no measurable effect upon the production of young bass. In years when small fish were removed from Ridge Lake in March prior to the bass spawning season and the bass spawn production was high $(19+3,19+5,19+7,19+9$, and 1951). it would have been difficult to measure accurately the effect of heavy angling, during the bass spawning season, upon the production of young bass. Judging from the behavior of bass in response to public frshing at Ridge Lake, however, I believe that the total effects of fishing (remosal of some spawning fish and the frightening of spawning and nest-guarding fish) would be less of a limiting factor in the production of young bass than would be the nest-robbing activities of a large population of bluegills.

Estimated survival rates for bass fry in the years $19+1,19+3,19+7$, and $19+9$ were 29 to 1,40 to 1,30 to 1 , and $3+$ to 1 , respectively, table 11 . At these rates of survival, the number of fry needed to replace the adults caught by fishermen at Ridge Lake in any single year would probably vary between 5,000 and 20,000. A few males bringing off successful hatches of fry would supply several times either of these numbers. Thus, unless fishermen were able to locate all of the nesting male bass in the lake and make a systematic effort to catch them, some males guarding nests would escape and bring off hatches of young in numbers more than adequate to replenish the population.

The purpose of a size limit on any sport fish is to allow individuals to reach sexual maturity and spawn, but, unless it can be shown that a large number of spawners produce greater numbers of young than a small number of spawners, there is no logic in holding to a minimum length limit. Most species of fish in some measure influence the survival of their own young; that is, when populations are high the success of spawning is low, and vice versa. Thus, if small "yearling" fish (fish spawned the previous year) of a species are taken by anglers without regard to size, the survival of current-seascn young of that species may be greater than if the "yearling" fish are not cropped. It seems reasonable to assume that, had fishermen been allowed to take bass of less than 10 inches in 1942 , survival of the spawns of $19+2$ and $19+3$ would have been higher than they were.

The only point that can be made in favor of a creel limit of 10 bass is that on certain very infrequent occasions bass lose their usual wariness and bite very readily: On these occasions, a limit of 10 fish may prevent an overenthusiastic fisherman from taking more fish than he can use.

A characteristic of the largemouth bass that greatly simplifies management is the fact that it spawns somewhat earlier than 
most other centrarchids with which it may be associated in a pond, and the young bass may be just enough larger than the fry of the other pond fishes to feed heavily upon them. Further, as the quantity of young bass produced is inversely related to the amount of interference with the nesting bass and to actual predation on the eggs and fry, all that is necessary to increase the numerical size of the bass population is to reduce the numbers of fish of the other species inhabiting the water with the bass. The resulting increase in the production and survival of young bass may vary from a few individuals to a brood or year-class so large that it dominates the fish population of the pond. When the individuals of a dominant brood of bass grow to a weight of 0.5 or 0.75 pound each, they may furnish excellent fishing.

There is some possibility that a fishthinning operation may allow, under some situations, the survival of too large a population of young bass, so that not only is a dominant brood produced, but the individuals may be so numerous that their food requirements exceed their food supply and they become stunted. Such a population of bass was produced in Ridge Lake in $19+1$. The $19+1$ year-class, which became stunted in $19+2$ at an average total length of 7.6 inches, could have been reduced to a numerical level that had food needs approximately commensurate with its food supply had fishermen in 1942 been freed from the state's legal restrictions of a 10-inch minimum length and a creel limit of 10 bass. Overabundant year-classes of bass did not develop in Ridge Lake after $19+1$ because enough bass of larger sizes were present in the lake to thin out the larger broods before the individuals reached postfingerling sizes. An overpopulation almost certainly would have resulted from the very large brood of bass that appeared in $19+5$ had not predation on this brood been high when it was in the fingerling stage.

In the 1945 and 1947 draining censuses at Ridge Lake, all bass below 10 inches in length were culled out and all larger bass were returned to the water. In the 1949 census, the minimum length of bass returned to the water was reduced to 9 inches and in the 1951 census to 8 inches.
There was no evidence that the reduction in minimum lengths of bass returned to the water after the 1949 and 1951 censuses had a significant effect upon the survival of bass spawn.

In studying the population dynamics of bass and bluegills at Ridge Lake, it is obvious that this combination of fishes in this impoundment would not produce a continuous high yield of bass over a period of years without considerable population adjustment at regular intervals. Bluegill spawning and survival in any 2 -year period between draining censuses was excessively high; the bass showed no great ability to control the number of small bluegills. Apparent failure of the bass to keep the bluegill population at a low level probably was related to the presence of a large crayfish population in the lake; the bass seemed to prefer crayfish to bluegills as food. Murphy (1949:162) found that bluegill fry were not an important item in the diet of the young bass of Clear Lake, Lake County, California, although small bluegills were relatively abundant in the lake at the time his study was made. The preference of bass for foods other than bluegills may be rather general and may have a great deal to do with the variable results that have been obtained from the bass-bluegill combination in some lllinois lakes.

The catch records at Ridge Lake show that bass rapidly lose their vulnerability to angling, so that, within a few days of the beginning of intensive fishing, the catch rate becomes discouraging to a large percentage of the fishermen, and most of the fish caught are taken by anglers who might rate as experts. There is no question that skill is important in catching bass. Records prove that certain fishermen are much more proficient than others. Superior ability to catch bass appears to be associated with the methods of "working" the lures.

The wariness of the largemouth bass is both encouraging and discouraging: encouraging to the aquatic biologist in that he can be certain that this bass will survive in numbers in spite of very heavy angling pressure (Bennett 1945:385); discouraging to the angler in that, unless he is an expert, his chances of making a good catch of bass in a public lake are rather poor. 
The bass at Ridge Lake seemed to retain their wariness during the fall months; even though the lake was closed to public fishing for 3 weeks or a month or more, the rate of catch in postseason test fishing operations was only a little better than during the summer. However, the bass apparently lost their wariness over winter and again became vulnerable to the average fisherman.

Ridge Lake was not opened to the public in $19+3$ and, in 19t4, not until the second week of August. During this closed period, Natural History Survey personnel were taking small samples of bass at regular intervals. These bass were taken by angling (as bass will seldom enter wing nets or traps in clear water), and were caught at a very high rate (average rate about 10 fish per hour). Most of these fish were rather small in size, and small bass are less wary than are large. But preseason fishing for all years, in some of which the average size of fish was much larger than in others, yielded fish at a very high rate. Preseason fishing in 1949 produced bass at the rate of nearly 3 pounds per man-hour, table 15 .

Our experience with bass has led us to believe that there is for each body of water a definite level of fishing intensity below which bass do not become "educated," and that it would be possible, in artificial ponds and lakes that are privately owned, for the owners so to regulate the intensity of fishing that small numbers of bass could be caught quickly and with little effort on the part of unskilled anglers.

What such a fishing intensity would be for a given body of water is a question that cannot be answered satisfactorily now. At Ridge Lake, it has been demonstrated that an opening-day fishing pressure of between 1.8 and 5.0 man-hours per acre concentrated within a thour morning period has been followed in the afternoon by a rather severe drop in the catch rate of bass.

Probably the most intensive fishing by Natural History Survey personnel at Ridge Lake was done during the period June 1 to 14 , inclusive, in 1949. when 17.75 hours of fishing yielded 50 bass weighing 52.49 pounds, table 15 . In this 14-day period, in which the lake was fished on 9 days, the fishing pressure never exceeded 0.36 man-hour per acre for any one day, and usually it amounted to about 0.05 to 0.07 man-hour per acre per day. Somewhere below the rate of 1.8 manhours per acre per day lies a range of fishing intensity within which bass apparently do not develop wariness. 'This range probably is influenced by the number of fishing hours per acre per day, by the amount of rest between periods of active fishing, and by the size and conformation of the lake basin. Certainly any lake owner may discover, after a few years of experimental fishing, coupled with a system of complete creel censusing, the approximate fishing intensity at which the catch rate for bass begins to fall off in his lake. It is assumed that during this period the lake is managed to maintain a large population of bass; otherwise, the testing of various fishing intensities would mean little.

The average length of life of its indiduals must be considered in the development of a management program for any species of fish. The largemouth bass is a relatively long-lived species, so that a bass of desirable size will probably remain available to the angler for a number of years. In most broods spawned in Ridge Lake, unaccountable losses among the medium-sized bass were usually much lower than among the bass of less than about 0.2 pound or more than about 3.5 pounds in weight, table 20 . In a location such as Ridge Lake, where fish may move out of the lake, over the spillway, in time of high water, a large part of the unaccountable loss among small bass may he due to random migration in search of better territory. Larimore (1952:10) demonstrated that smallmouth bass in streams have definite territorial instincts and that the smaller fish have less welldefined territories than have the larger ones, presumably because the smaller fish are less able to hold desirable territories.

There is some evidence (largely in popular literature on bass fishing) that individual largemouth bass in lakes have been repeatedly recaptured in definite locations over periods of time. If the largemouth is similar to the smallmouth in territorial instincts, it is not difficult to explain the movement of small bass out of a lake 
when the opportunity arises. This loss of small fish is not considered serious; rather, in many situations it must be considered beneficial, because one objective of a bass management program is to bring the young fish up to desirable sizes as rapidly as possible, and the thinning of a crowded population by loss of individuals over a spillway would allow an improvement in the rate of growth of the fish remaining. 'That movement of young fish out of Ridge Lake may be random was indicated by the continuation of a crowded population of bass all through the $19+2$ season, although bass could have moved out of the lake over the surface spillway following seven or eight different storms that occurred in May, June, and July, fig. 5.

The brood of bass spawned in Ridge Lake in $19+1$ had been reduced to four individuals by 1951 , table 20 . The age attained by these four bass is probably near the maximum for largemouths in the latitude of Illinois. For the $19+1$ brood, the unaccountable loss, which includes the loss resulting from natural deaths, was 39.1 per cent in the 19491951 period, whereas in the 1947-1949 period it was only 9.8 per cent.

The catches of bass for the individual years $19+t$ through 1950 , which ranged from 31.0 to 62.4 per cent of the marked fish in the lake, table 19, may be considered to represent high exploitation rates for a species of fish that has a normal life span of 8 to 10 years in the latitude of central Illinois. 'That these exploitation rates were not excessive for the Ridge Lake population was indicated by the fact that there was a comparatively high poundage of bass present when the lake was drained in 1951, table 7 , after 7 years of these rates. It is true that in this period the yield of bass in numbers and total poundages, table 6 , and pounds per acre, table 8 , varied a great deal from year to year, but 1 can see no upward or downward trends in population abundance that can be clearly associated with rates of exploitation.

So little information is available on exploitation rates of bass in other bodies of water that it is impossible to make a comparative evaluation of the exploitation rates at Ridge Lake. The high bass fry production in alternate years, table 9 , was important in that it assured adequate replacements for fish caught, regardless of the exploitation rate.

Today (June, 195t) descendants of the 435 bass with which Ridge Lake was stocked in $19+1$ are still rising to the lures of some of the fishermen who caught their great-great-great-grandparents in 1942. These present-day fish and the thousands that have inhabited the lake in the period since $19+1$ are mute evidence that the largemouth bass will respond to a few simple management techniques. The fish technician or the pond owner who knows when and how to apply these techniques need never worry for the future of bass fishing.

\section{Summary}

1. Ridge Lake, the dam for which was completed in April, 1941, is an artificial impoundment that at overflow level in $19+1$ had an area of 18.1 acres and a maximum depth of 25 feet. It was made by damming Dry Run Creek, a tributary of the Embarrass River, in Coles County, Illinois. Both tower and surface spillways were constructed. 'The tower spillway was provided with a gate valve to be used in draining the lake basin. A permanent laboratory was built on the south shore of the lake about midway between the dam and the upper end. Silting of the lake basin was and is a serious problem, as much of the 902-acre watershed drains into the lake through steep-sided ravines, some of them pastured. The lake is eutrophic-like in character in that it has no dissolved oxygen in the deep water in summer, except when the cool oxygendeficient water is flushed out of the lake through a tower spillway by the entrance of surface runoff into the lake basin after heavy rains.

2. The lake was stocked in $19+1$ with +35 bass, table 2 , in $194+$ with 129 bluegills, and in $19+9$ with 138 warmouths. In 1942 and most subsequent years, the public was allowed to fish from boats belonging to the Natural History Survey, and a record was made of kinds, numbers, and weights of all fish caught, table 6 . time spent in fishing, table 15 , kinds of baits, table 22, and the tackle used. A few scales were taken from each of the 
bass caught and from most of the larger bluegills and used later for age analyses. 'The lake was closed to public tishing in $19+3$ and until August in 19+4.

3. At intervals of 2 years, beginning in $19+3$, the lake was drained in early spring and a census was made of the fish, table + . Five censuses were made in the 19+1-1951 period covered by this study. After each census, the large bass (min1mum length 10 inches in most years, 8 or 9 in others) were marked by tin-clipping and returned to the partially refilled lake basin, table 5 . After each draining, except that of $19+9$, the lake basin had completely refilled before the beginning of the summer fishing season. In 1949, the basin had only partially refilled; the water covered an area of about 11 acres on June 1 and remained practically constant in area until November.

t. No stocks of fish, other than the +35 bass released in $19+1$, the 129 bluegills released in $19+4$, and the 138 warmouths released in 19+9, were introduced into Ridge Lake from other bodies of water. In the study period, which began in the spring of $19+1$ and ended after the bass spawning season but before the angling season of 1951, more than 11,000 bass and $15+, 000$ bluegills were permanently removed from the lake by angling and in draining censuses, table 3 . Of these, $3,7+3$ bass and about 9,000 bluegills were taken by anglers; the others were taken in draining operations as excess small fish. In the 19+9-1950 period, few warmouths were caught by anglers and less than 1,000 were taken in the 1951 draining census, table t. About 3,500 fish other than bass, bluegills, and warmouths were taken from the lake (mostly in draining operations) during the study period, table 3. These, which included green sunfish, black bullheads, yellow bullheads, carp, and a black buffalo, were of species indigenous to Dry Run Creek and the Embarrass River. Although large numbers of bass and bluegills were removed from Ridge Lake during the study period, these fish were als numerous in Ridge Lake in 1951 as they had been at any other time during the 10 -year period, table 4 .

5. The weight of bass taken in the five draining censuses ranged from 31.5 pounds per acre in the $19+7$ census to 50.4 pounds per acre in the $19+9$ census, table 7. In three censuses, those of $19+3,19+9$, and 1951, the weight of bass was 48.2, 50.4, and +9.9 pounds per acre, respectively. These poundage calculations suggest that the carrying capacity of Ridge Lake for bass may be about 50 pounds per acre. Once the bluegill population had become well established in Ridge Lake, poundages per acre of bluegills varied between 86.9 and 193.3; the largest poundage of bass was found with the smallest poundage of bluegills (1949 census) and the largest poundage of bluegills with the smallest poundage of bass (19+7 census), suggesting interspecific competition.

6. Yields of bass taken by angling during years in which the lake (an 18-acre area assumed) was open to public fishing varied between 10.9 and 30.0 pounds per acre, table 8 ; yields of bluegills varied between 6.2 and 45.9 pounds per acre. Fishing pressure ranged from 90 man-hours per acre in $19+4$ to 320 man-hours per acre in 1948, table 18.

7. Estimates of numbers of bass fry were made during the spawning season of each year, 1941 to 1951 , inclusive, table 9. In years in which the lake was drained and small fish were removed in March, the estimates of numbers of fry varied between 18,000 and 116,000 , with an average of 50,500 . In years in which the lake was not drained in March and small fish were present, the estimates of numbers of bass fry ranged from 0 to 26,000 , with an average of 5,900 . Schooling bass fry were observed prior to June 1 in only 3 years out of 11 .

8. There was no apparent relationship between the number of bass of spawning age in the lake in any given season and the number of bass fry produced in that season, table 10 . Years in which small fish were abundant in the lake (particularly those years in which many small bluegills were present) were years of low production of bass fry.

9. The ratios of numbers of bass fry of a brood to individuals of the same brood taken as larger fish in the 21 months after spawning varied between 29 to 1 and 40 to 1 , in $1941,1943,1947$, and 1949 , table 11. In 1945, when the number of bass fry produced was unusually large, the survival ratio was 195 to 1 . 
10. Bass at Ridge Lake averaged 8.1 inches total length at 1 year of age, 10.3 inches at 2 years, 12.6 inches at 3 years, and 13.7 at + years, table 13 . Bluegills averaged 4.7 inches total length at 1 year of age, 6.2 inches at 2 years, and 7.1 inches at 3 years, table 14 .

11. In $19+9$, bass fishing dropped from a preseason calculated catch rate of 2.96 pounds per man-hour to a rate of 0.18 pound per man-hour on the second day of the public fishing season, table 15. 'The calculated rate of catch in the afternoon period of the first day of the fishing season in each year in which public fishing was allowed was less than half that of the morning, table 16. By the third day of the fishing season in each of these years except 1944 , the calculated rate of catch was less than one-third that of the opening morning. In no year was the catch in numbers or pounds on the opening morning more than 6.3 per cent of the available number or poundage of fish in the lake. For years in which large numbers of bluegills as well as bass were available, the calculated seasonal catch rate for bass and bluegills together was 0.19 pound per man-hour; for years in which bass were essentially the only fish available, the calculated seasonal catch rate for bass was 0.13 pound per man-hour, table 17 . Actual rates of catch were probably 50 to 100 per cent higher than the calculated rates because time spent in rowing boats was counted as fishing time.

12. Some of the factors influencing the yield of bass in any given fishing season were the number and weight of bass available, the fishing pressure, and the amount of natural food available for bass. While all of these factors undoubtedly were important in determining the bass vield, the highest catches, in terms of number and weight of bass available, were made in years when small fishes and other bass foods were reduced through lake draining prior to the fishing season, table 18 . In these years, yields of bass from angling varied between +5 and $6+$ per cent of the number and between 40 and 69 per cent of the weight of bass available. In years (after 19+3) when the lake was not drained prior to the fishing season, the yields of bass from angling varied between 23 and to per cent of the number available and between 27 and $3+$ per cent of the weight available.

13. In the 2-year period preceding the first draining census and in each of four 2-year periods between draining censuses, numbers of bass that had been marked by fin-clipping disappeared from Ridge Lake. These bass could have died from injuries or from natural causes without being recovered, they could have moved out of the lake over the surface spillway in time of flood, or they could have been removed through illegal fishing when the lake was closed. The unaccountable losses among the bass with which the lake was originally stocked amounted to 86.7 per cent in the 19+1-19+3 period, table 19; the losses were so high as to suggest that many of these fish died from injuries received in transportation or handling. Among the bass produced in the lake and later marked, unaccountable losses were lower in the middle age groups than in older and younger age groups. As bass approached the age of 10 years, the unaccountable losses increased, suggesting that the fish were approaching the end of their normal life span.

14. Artificial lures were more effective in catching bass than were live or other natural baits, table 22. Fishermen tended to try artificial baits at the start of each fishing period, switch to natural baits if the artificials were ineffective, and, if natural baits also were ineffective, continue to use them, thus building up many "low catch" hours for the natural baits. Catch records for individual fishermen demonstrated that skill was important to success in bass fishing.

15. For their contingent travel, meals, tackle, and licenses, fishermen at Ridge Lake in 1949 are estimated to have spent an average of $\$ 1.22$ for each hour of bass fishing. Because they averaged 7.1 hours in catching 1 pound of bass, the calculated cost of their catch was $\$ 8.66$ per pound. 


\section{LITERATURE CITED}

American Fisheries Society

1948. A list of common and scientific names of the better known fishes of the United States and Canada. Am. Fish. Soc. Spec. Pub. 1. 45 pp.

Bennett, George W.

1943. Management of small artificial lakes: a summary of fisheries investigations, 1938-1942. III. Nat. Hist. Surv. Bul. 22(3):357-76.

1945. Overtishing in a small artificial lake: Onized Lake near Alton, 1llinois. Ill. Nat. Hist. Surv. Bul. $23(3): 373 \multimap 06$.

1946. Pond talk-II. III. Wildlife I (2):8-10.

1951. Experimental largemouth bass management in Illinois. Am. Fish. Soc. Trans. 80(1950): $231-9$.

Bennett, George W., and Leonard Durham

1951. Cost of bass fishing at Ridge Lake, Coles County, Illinois. 111. Nat. Hist. Surv. Biol. Notes 23. 16 pp.

Bennett, George W., David H. Thompson, and Sam A. Parr

1940. Lake management reports. 4. A second year of fisheries investigations at Fork Lake, 1939. Ill. Nat. Hist. Surv. Biol. Notes 14. 24 pp.

Brown, Frank A., Jr.

1937. Responses of the large-mouth black bass to colors. Ill. Nat. Hist. Surv. Bul. 21 (2) :3355 .

Durham, Leonard, and George W. Bennett

1949. Bass baits at Ridge Lake. Ill. Wildlife $4(2): 10-3$.

1951. More about bass baits at Ridge Lake. Ill. Wildlife 6(2):5-7.

Eschmeyer, R. W.

1942. The catch, abundance, and migration of game fishes in Norris Reservoir, Tennessee, 1940. Tenn. Acad. Sci. Jour. I7(1):90-115.

Fleming, Woodrow Wilson

1949. Some physical, chemical and biological characteristics associated with aquatic vegetation in Ridge Lake. Master's thesis, University of Illinois, Urbana. 53 pp.

Hubbs, Carl L., and Karl F. Lagler

1947. Fishes of the Great Lakes region. Cranbrook Inst. Sci. Bul. 26:1-186.

Larimore, R. Weldon

1952. Home pools and homing behavior of smallmouth black bass in Jordan Creek. Ill. Nat. Hist. Surv. Biol. Notes 28.12 pp.

Markus, Henry C.

1932. The extent to which temperature changes influence food consumption in largemouth bass (Huro floridana). Am. Fish. Soc. Trans. 62(1932) : 202-10.

Meehean, O. Lloyd

1942. Fish populations of five Florida lakes. Am. Fish. Soc. Trans. 71(1941): $184-94$.

Murphy, Garth I.

1949. The food of young largemouth black bass (Micropterus salmoides) in Clear Lake, California. Calif. Fish and Game 35(3):159-63.

Ricker, William E.

1942. Creel census, population estimates and rate of exploitation of game fish in Shoe Lake, Indiana. Ind. Dept. Cons., Div. Fish and Game, and Ind. Univ. Dept. Zool., Invest. Ind. Lakes and Streams 2(12):215-53.

19+5. Natural mortality among Indiana bluegill sunfish. Ecology 26(2):111-21.

Stall, J. B., L. C. Gottschalk, A. A. Klingebiel, E. L. Sauer, and S. W. Melsted

1951. The silting of Ridge Lake, Fox Ridge State Park, Charleston, Illinois. Ill. State Water Surv. Rep. Invest. 7. 35 pp.

Swingle, H. S.

1950. Relationships and dynamics of balanced and unbalanced fish populations. Ala. Polytech. Inst., Ag. Expt. Sta., Bul. 274. 74 pp.

Swingle, H. S., and E. V. Smith

1941. Experiments on the stocking of fish ponds. N. Am. Wildlife Conf. Trans. 5:267-76. 


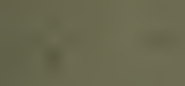

,

a 
